\title{
Comparative analysis for the pre-school institutions in Municipality of Centre with modern tendencies in designing and articulations of specific interventions in space as a result of the psycho-physical needs by the children
}

Boris lliev ${ }^{*}$

PhD student in Wood Scinse and Technology, Faculty of Forestry, University of Zagreb, Croatia

Citation: Iliev B. [Comparative analysis for the pre school institutions in Municipality of Centar with modern tendencies in designing and articulations of specific interventions in space as a result of the psycho-physical needs by the children]. SEE J Archit Des. 2017 Nov 09; 10024.

Keywords: Pre-school institutions; Playrooms; Designing children"s furniture, Municipality Centar; Space corresponds to child size; Psycho-physical development

*Correspondence: Boris lliev. PhD student in Wood Scinse and Technology, Faculty of Forestry, University of

Received: 01-Jul-2017; Revised: 20-Jul-2017; Accepted: 30- Oct-2017; Published: 09-Dec-2017

Copyright: $\odot 2017$ Boris lliev. This is an open-access article distributed under the terms of the Creative Commons Attribution License, which permits unrestricted use, distribution, and reproduction in any medium

Competing Interests: The author have declared that no competing interests exis

\section{Abstract}

Main subject for the research in this paper are the pre-school object / buildings in the Municipality of Centre, where throughout comparative analysis we get concrete solutions for improving the psycho-physical needs by the pre-school children. With proper space organization and proper use and heat comfort which is key condition for unspoiled development of all functions set by the needs of the children.

Playrooms as central rooms in the pre-school buildings, where all the functions of the children during the day are carried out, are subjected to a major articulation and specific interventions. With proper conception of the inner space in the building and use of proper equipment, the play room will be transformed in a place where the children will have healthy and adequate growth and development.

The use of furniture which is suitable to the proportions of the pre-school children has key influence for proper body development of the children. Therefore in this paper I used anthropometric analysis to the pre - schoo children, where throughout the relevant figures we can fulfil proper projection of the furniture elements which are used in pre-school institutions. 
Компаративна анализа на предучилишните установи во општина Центар со современите тенденции во проектирањето и артикулирање на одредени интервенции во просторот како одговор на психо- физичките потреби на децата

\section{АБСТРАКТ}

Во овој труд предмет на истражувањето преставуваат предучилишните објекти во општината Центар каде преку компаративна анализа се даваат конкретни решенија за подобрување на психофизичките потреби на предучилишните деца. Со правилна просторна организација и правилна употреба на материјалите се постигнува визуелен, акустичен и топлотен комфор кој е главен предуслов за непречено одвивање на сите функции условени од потребите на децата.

Занималните како централни простории во предучилишните објекти, каде се одвиваат сите фрункции на децата преку целиот ден, подлежат на најголемо артикулирање на одредени интервенции. Со правилно концепирање на просторот и употреба на соодветна опрема, занималната станува место во кое децата правилно растат и се развиваат.

Употребата на мебел кој одговара на пропорциите на предучилишните деца е од круцијално значење за правилното развивање на телото. Затоа во овој труд ce направени антропометриски анализи на предучилишните деца, каде преку добиените податоци може да се постигне правилно проектирање на елементите од мебел кои се користат во предучичишните установи.

кЛУЧнИ ЗБОРОВИ

предучилишни установи, занимална, дизајнирање на детски мебел, општина Центар, артикулирање на простор, антропометрија на деца, мебел кој кореспондира на детската големина, психо-физички развој. 
Comparative analysis for the pre school institutions in Municipality of Centar with modern tendencies in designing and articulations of specific interventions in space as a result of the psycho-physical needs by the children.

\section{ABSTRACT}

Main subject for the research in this paper are the pre-school object/buildings in the Municipality of Centar, where through out comparative analysis we get concrete solutions for improving the psycho-physical needs by the pre-school children. With proper space organization and proper use and heat comfort which is key condition for unspoiled development of all functions set by the needs of the children.

Playrooms as central rooms in the pre-school buildings, where all the functions of the children during the day are carried out, are subjected to a major articulation and specific interventions. With proper conception of the inner space in the building and use of proper equipment, the play room will be transformed in a place where the children will have healthy and adequate growth and development.

The use of furniture which is suitable to the proportions of the pre-school children has key influence for proper body development of the children. Therefore in this paper I used anthropometric analysis to the preschool children, where through out the relevant figures we can fulfill proper projection of the furniture elements which are used in pre-school institutions.

\section{KEY WORDS}

pre-school institutions; playrooms; designing children's furniture; Municipality Centar; space articulation; anthropometrics of children; furniture which corresponds to child size; psycho-physical development. 
ВОВЕД

\section{СОДРЖИНА}

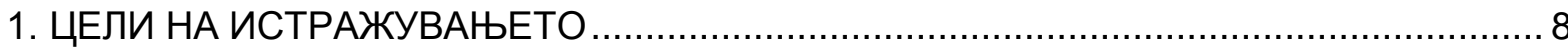

2. МЕТОДИ НА ИСТРАЖУВАЊЕТО ................................................................ 9

3. ИСТОРИСКА ГЕНЕЗА НА ПРЕДУЧИЛИШНИТЕ УСТАНОВИ ................................ 10

4. ЕДУКАТИВНИОТ ПРОЦЕС ВО РЕПУБЛИКА МАКЕДОНИЈА И ОРГАНИЗАЦИОНАТА ПОСТАВЕНОСТ НА ПРЕДУЧИЛИШНИТЕ УСТАНОВИ .......................................... 14

4.1. Категоризација на предучилишните установи ............................................. 14

4.2. Стандарди за капацитетот на предучилишните установи ............................. 14

4.3. Големина на предучилишните установи .................................................... 16

4.4. Статистички податоци за предучилишните установи.................................... 17

4.5. Организација на предучилишните установи според дневниот престој ............ 18

5. ДОСЕГАШНИ СОЗНАНИЈА ВО ИСТРАЖУВАЧКАТА ОБЛАСТ .................................. 19

5.1.Антропометриска анализа потребна во предучилишните установи................ 19

5.2.Типологија на предучилишните установи ............................................... 20

5.2.1 Простории каде престојуваат децата....................................................2 21

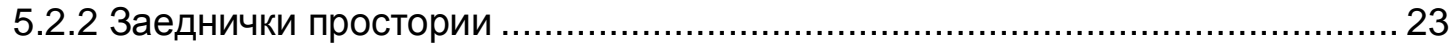

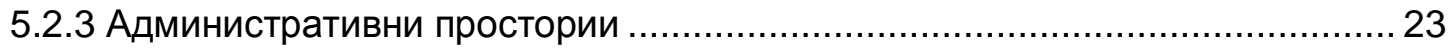

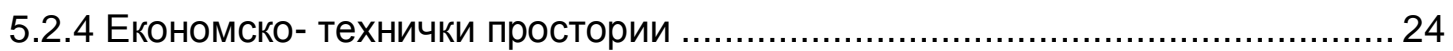

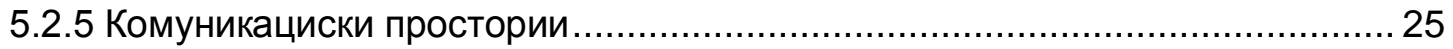

5.3.Светло и осветлување на предучилишните установи....................................26

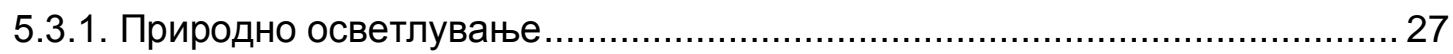

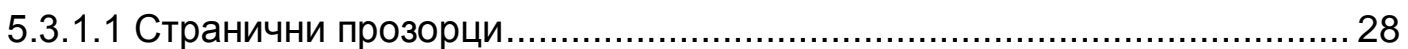

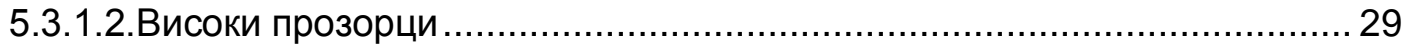

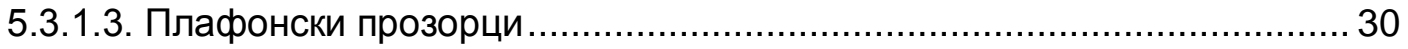

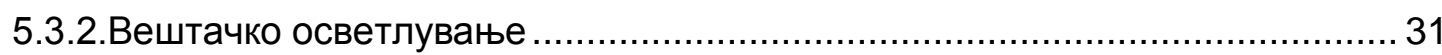

5.4.Топлотни потреби во предучилишните установи ........................................... 32 
5.5.Акустични потреби и звучна заштита во предучилишните установи . 34

5.5.1.Норматив за звучна заштита на предучилишните установи 37

6. КОМПАРАТИВНА АНАЛИЗА НА ПРЕДУЧИЛИШНИТЕ УСТАНОВИ ВО ОПШТИНА ЦЕНТАР СО ПОСТОЕЧКИТЕ СТАНДАРДИ ВО ПРЕКТИРАЊЕТО 38

6.1. Анализа на предучилишните установи во општина Центар со современи тенденции .

6.1.1. Предучилишни објекти кои влегуваат во состав на групацијата на установи „13-ти Ноември“.

6.1.1.1. Комбинирана детска установа „13-ти Ноември“ 39

6.1.1.2. Детска градинка „Кукушка“ 42

6.1.1.3. Предучилишна установа „Јасмин“ 42

6.1.1.4. Комбинирана детска установа „Парк“. 46

6.1.2. Предучилишни објекти кои влегуваат во состав на групацијата на установи „Кочо Рацин“... 50

6.1.2.1. Предучилишна установа „Кочо Рацин“ 50

6.1.2.2. Предучилишна установа „Бели Мугри“. 52

6.1.2.3. Предучилишна установа „Панорама“. 55

6.1.2.4. Прдучилишна установа „Наум Наумовски-Борче“. 59

6.1.3. Предучилишни објекти кои влегуваат во состав на групацијата на установи „Раде Јовчевски-Корчагин“

6.1.3.1. Предучилишна установа „Раде Јовчевски-Корчагин“. 61

6.1.3.2. Комбинирана детска установа „Пепелашка“ 65

6.1.3.3. Детска градинка „Палешка“. 65

6.2. Анализа на предучилишните установи 70

7. АНТРОПОМЕТРИСКА АНАЛИЗА НА ПРЕДУЧИЛИШНИТЕ ДЕЦА, ДОБИЕНА ПРИ ИСТРАЖУВАЊЕ НА ПРЕДУЧОЛИШНИТЕ УСТАНОВИ 77

8. АРТИКУЛИРАЊЕ НА ОДРЕДЕНИ ИНТЕРВЕНЦИИ ВО ПРОСТОРОТ (ЗАНИМАЛНИТЕ) КАКО ОДГОВОР НА ПСИХО-ФИЗИЧКИТЕ ПОТРЕБИ НА ДЕЦАТА 85

8.1. Артикулирање на одредени интервенции во занималните 85

8.1.1. Спиење . 85 
Компаративна анализа на предучилишните установи во општина Центар со современите тенденции во проектирањето и артикулирање на одредени интервенции во просторот како одговор на психо-физичките потреби на децата

8.1.2. Јадење......

8.1.3. Играње......

8.1.4. Воспитно-образовни активности 93

8.2. Други параметри кои влијаат врз модификацијата на просторот- занималната..

9. ДИСКУСИЈА. 96

ЗАКЛУЧОК 108

БИБЛИОГРАФИЈА 112 


\section{ВОВЕД}

Правилниот развој на предучилишните деца на возраст од една до шест години, период во кој се случуваат најголемите промени во развојот и кога личноста на детето ја фрормира својата основа за здрав психо- физички живот, претставува примарна одговорност за секое општество. Затоа, предучилишните установи треба да ги исполнуваат основните услови за правилна нега, грижа и здрав развој во воспитно-образовниот процес на децата.

Од вкупниот број на предучилишни деца во Република Македонија само $11 \%$ посетуваат предучилишни установи. Брзото темпо на живеење, борбата за егзистенција, работните обврски на двата родитела, наметнаа потреба се почесто децата да бидат згрижени во предучилишни установи. Ова пак ја наложува потребата од нови предучилишни објекти. Бидејќи стандардите и нормативите од година во година се менуваат и усовршуваат, неопходна е интервенција во просторот кај постоечките објекти.

Во градските подрачја со високо сегрегирано население, со јазични бариери и културни разлики, детските градинки обезбедуваат можност популацијата да се интегрира, бидејќи децата многу лесно воспоставуват комуникација и социјална интеракција. Архитектурата може да помогне во овој процес, претставувајќи социјален катализатор. Затоа проектирањето на предучилишни установи или нивната одредена артикулацина на одредени простории е многу чуствителна. Крајните корисници на овие објекти, децата, треба да се идентификуваат со овие институции со цел да се поттикне рационален, емоционален и најмногу од се личен став, за да можат предучичишниот објект да го чуствуваат како свој втор дом. Од друга страна, преку едукативниот процес кој се спроведува во овие установи тие многу полесно можат да ги совладаат и прифатат задачите кои им се задаваат од наставниците. Сето ова може да се постигне само врз основа на квалитетот на просторниот амбиент и опремата во него.

Изградбата на нови современи објекти најчесто е премногу скапа инвестиција, па оттука најпогоден, најбрз и најекономичен начин е можноста за артикулирање во самите објекти. При започнувањето со одредени интервенции во објектите треба да се направи опсежна анализа во која задолжително треба да бидат вклучени експерти од различни области. Покрај архитекти, дизајнери, проектанти на мебел треба да бидат консултирани и педагози, психолози родители, како би се добил погоден простор во кој децата психо - физички правилно би се развивале. 
Занималните, во кој се извршуваат сите активности во текот на денот би требало да бидат најмногу подложни на промени и адаптација. Правилната организација доведува децата да стекнат добри навики за извршување на своите обврски, да ја подобрат социјалната интеракција, како подготовка за понатамошниот живот.

Покрај правилната организација, битен елемент за развој на децата преставува и правилниот начин на седење и извршување на задачите во седечка положба. Затоа правилно проектираните елементи од мебел кои одговараат на нивната возраст е од круцијално значење, за правилно оформување на нивните тела. За да се испроектираат елементи на мебел кои ќе кореспондираат на нивната висина, треба да се посвети големо внимание на антропометријата на децата. 


\section{1. ЦЕЛИ НА ИСТРАЖУВАЊЕТО}

Цел на истражување во овој труд е потребата од изнаоѓање квалитетно решение за подобрување на условите во просториите каде децата престојуваат, од аспект на просторната организација, визуелен, топлински и акустичен комфор. Преку задоволување на наведените компоненти се добива атмосфера во која децата правилно растат и се развиваат. Преку конкретни примери може да се лоцираат недостатоците во предучилишните објекти и истите да се отстранат. Така во трудот преку компаративна анализа на предучилишните установи во општина Центар, се доаѓа до конкретно решение за конципирање на одредени својства на просторот, како одговор на детските психолошки развојни потреби.

Занималната како средишен простор каде се одвиваат сите функции во текот на денот, е најподложна на артикулација во конципирање, проектирање и опремување, што придонесува до квалитетна средина во која децата престојуваат.

Мебелот кој го користат децата во предучилишните установи преставува исто така битен елемент во развојот на децата. Преку антропометриски анализи направени во предучилишните објекти се доаѓa до сознанија кои понатаму можат да послужат за проектирање на мебел. Истражувањето на антропометријата на децата ќе овозможи преку добиените резултати да се направи споредба со постоечкиот мебел и да се проектира и изработи мебел кој во целост ќе кореспондира со мерките на децата. 


\section{2. МЕТОДИ НА ИСТРАЖУВАЊЕТО}

Во трудот се користени повеќе модети на истражување според потребите од добивање на соодветни информации:

Метод на директно мерење- преку кој се добиваат одредени податоци за димензиите на просториите и елементите потребни за целите во трудот.

Статистички метод- преку овој метод се користат одредени статисктички методи за откривање на општата тенденција на одредена појава.

Дискриптивна метода- даден е опис на развојот на предучилишните установи, како и опис на предучилишните установи во општина Центар.

Компаративна метода- преку која се прави компарација на предучилишните установи во општина Центар, со цел да се добијат конкретни податоци, за тоа какви промени се потребни во просториите каде престојуваат децата.

Аналитичко-синтетичка метода, преку која низ еден мултидисциплинарен приод се анализира просторната организација на предучилишните установи и занималните, како простор во кој се извршуваат сите функции на децата во текот на денот. Исто така се анализираат и сите составни делови кои се употребуваат при артикулирање на одредени интервенции во просторот, при што се користени сознанија од архитектурата, градежништвото, антропометријата и од природните науки.

Метод на конкретни мерења на човековото тело (антропометрија)метод преку кој се добиени одредни мерки извршени на предучилишните деца. 


\section{3. ИСТОРИСКА ГЕНЕЗА НА ПРЕДУЧИЛИШНИТЕ УСТАНОВИ}

Проектирањето на установи во кои престојувале деца од петтата, до осумнаесттата година се познати со векови наназад, како што биле военогимнастичките школи во Спарта, школите gramatista, школите gitarista n гимназиумите во Атина, преку школите ludus и humanitas во Римската империја. За разлика од установите кои ја опфаќаaт училишната возраст, предучилишните установи во кои престојувале деца од раѓање до шестата година првпат се споменуваат во XIX век.

Во средниот век децата не биле третирани како посебна психолошка група со свои потреби и сфаќања за животот, како што тоа денес го третира современата педагогија и психологија. Во раниот среден век - X и XI век детето растело и се развивало исклучиво меѓу возрасните, без да му се обезбеди специјална грижа, преку негово одвојување од групата на возрасните. Особено во неговите први години на детето се гледало како на мало, мило суштество. Претставувало еден вид на играчка, со третман ист на животно, домашно милениче, кое служело само за забава ${ }^{1}$. Откако ќе поминело раното детство, најчуствителниот период за секое дете, веднаш се мешало со возрасните. Пред него не се криело ништо и можело да чуе и види сешто ${ }^{2}$.

Во семејствата од средниот век децата не добивале соодветна љубов, емоционална сигурност, социјализација и образование, бидејќи семејството не се засновало на овие принципи, туку на животната потреба да се одржи потомството и обезбеди егзистенцијата.

Подоцна, мислењето за детето односно детството постепено се менувало и довело до негово постепено одвојување од светот на возрасните. Детето во семејството го заземало своето место, почнува грижата кон него, не станува централна оска, но сепак станува негов составен дел.

Детството, како безначаен период од развојот на човекот, се сметал се до XVII век, кога со појавата на моралистите станува предмет на интересирање. На детето се гледало како на беспомошно битие, на кое треба да му се обрне особено внимание и љубов и кое задолжително треба да се воспитува и да му се обезбеди образование, за да порасне и да се развие во созреана личност. Оттогаш до денес, погледот кон детето се менувал и усовршувал како на психолошки, така и на образовно-воспитен план. Така, тепањето на децата со камшик во XVII век почнало да се изоставува, бидејќи се сметало дека ја понижува душата, со исклучок на Англија, каде се задржало подолго време. Децата кои биле праќани во училишта, занаетчиски работилници или манастири, биле мешани без да се води сметка за возрасната

\footnotetext{
${ }_{1}^{1}$ Каменов, Емил. Предучилишна педагогија. книга прва. Скопје: просветно дело, 1988. Стр103

${ }^{2}$ Ариес, Филип. Векови Детинства. Београд: Завод за удџбениике и наставна средства, 1989 стр102
} 
граница или класната положба на детето од семејствата од кои доаѓаaт. Со појавата на буржоазијата децата почнале да се делат според класната разлика и припадност. Во XIX век почнало издвојувањето на детето од сопственото семејство, со сместување во интернати. Оваа форма на образование во овој период се сметала за идеален облик на воспитание. Кон крајот на XIX век сфаќањето околу интернатите се изменило, така што современето семејство не го прифаќало одвојувањето на таков начин на детето од своето семејство.

Во современото општество на детето се гледа како на посебна индивидуа. Семејството почнува да се организира околу него и да му придава огромно значење. Индустрилизацијата и современото сфаќање на децата овозможија отворање на предучилишни установи, во кои се врши згрижувачка, образовна и воспитна дејност. Во предучилишните установи покрај тоа што престојуваат деца чии родителите не се во состојба да се грижат за детето во текот на целиот ден, престојуваат и оние кои не се засегнати од оваа состојба, туку поради социјализирање и правилно напредување на детето.

Идејата за појава на детски предучилишни установи постои уште од XVII век, кога мала група на граѓани од Европските земји се заинтересирале за социјалните промени во кои влегувала и идејата за правилен пристап кон децата. Тие сметале дека преку правилен развој на децата се создаваат здрави личности подготвени за понатамошниот живот, а сето ова е овозможено со правилно образование уште од најмалата возраст.

Почетоците на еден вид детски предучилишни установи се појавуваат во втората половина на XVIII век, кога е забележан и податокот за групирање на мали детски групи во Steithal, во Waldersbach. Според некои стари хроники од 1772 година ${ }^{3}$, постојат податоци за формирање на групи деца во замоците, со цел децата да бидат згрижени во времето додека нивните мајки работеле. Организирана форма на институционално ниво во која се одвивала грижа за децата биле сиропатилиштата, каде се згрижувале децата без родители.

Јохан Хајнрих Песталоци го основал првиот институт за деца во Yverdon во 1805 година. Иако не бил специјализиран за мали деца, тој сепак претставувал основа за понатамшен развиток на градинките. Десет години подоцна, следејќи го примерот од Yverdon, фрилантропот Роберт Овен формирал институт за грижа на деца во Њу Ланарк, индустриска зона во Шкотска.

Фредерих Фробел, германски педагог и ученик на Песталоци, основал модерни гледишта кон детската педагогија и го изложил својот став дека децата имаат свои потреби и сфаќања различни од возрасните. Тој создал

\footnotetext{
${ }^{3}$ Šekularac, Ivanovič Jelena. Predškolske ustanove I komfor. Str16
} 
предучилишни установи, чиј пример го следеле сите европски земји и северна Америка. Неговата фрилозофија се состоела во тоа дека градинките треба да бидат дополнување во животот на децата, а не замена за нивниот дом. Во Германија, по револуционерните гледишта на Фробел од 1840, биле отворени предучилшни установи во сите поголеми центри

Првата градинка во северна Англија по примерот на Фробел била отворена во 1871 година во Салфорд, наречена „слободна градинка“. Овој термин можеби е оправдан бидејки била основана пред се за помалку привилегираната работничка класа. Под влијание на Англија следело отворање на првите предучилишни установи во С.А.Д., во Бостон во 1892 година и во Сент Луис, Мизури во 1893 година. ${ }^{4}$

Во градовите, посебно оние во Англија, каде индустријализацијата заземала голем зафат, отворањето на предучилишни установи била единствена опција, за згрижување на децата, додека нивните родители се бореле со жестоката егзистенцијална реалност. Овие градинки поради финансиска оправданост биле отворани во трошни објекти или напуштени индустриски простории.

Пред и за време на Првата светска војна грижата за децата особено била од интерес во универзитетските установи во С.А.Д., со што се охрабрила идејата за изградба на предучилишни установи, кои би ги задоволувале барем основните, минимални услови, за кои тие се наменети. Во Европа, многу помалку во Англија, интересот за децата и нивната психологија главно била иницирана од организации кои се занимавале со проблематика од оваа област или преку хуманитарни религиски групи.

Првиот типичен предучилишен објект бил основан во Лондон во 1913 година од Маргарет Мек Милан. Во него престојувале сиромашни деца, кои престојувале во колиби.

СЛИКА $1^{4}$

Детската градинака на Маргарет Мек Милан, Депфорд, јужен Лондон, 1923

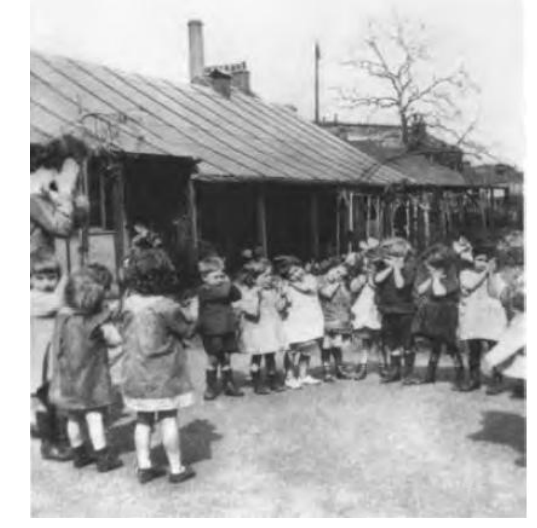

\footnotetext{
${ }^{4}$ Dudek, Mark. Kindergarten architecture. Second Edition. London: Spon Press, 2000. Стр. 32
} 
Денешниот изглед градинките почнале да го добиваат по 1920-та година, кога почнале да се градат револуционерни градби со користење на нови материјали. Многу архитекти биле вклучени во создавањето на уникатни објекти од овој тип. Меѓу нив бил Валтер Гропиус кој во 1937 година ја дизајнирал неизградената предучилишна установа за Clary Peabody Trust. Значајна е да се спомене не само по архитектонскиот стил, туку и по просторната организација на самиот објект. Тука се вбројува и Ле Корбизије со уникатната идеја за изградба на детски простор на врвот од зградата Unitè. Други познати архитекти, дизајнери кои учествувале во создавањето на предучилишните установи се Паул Кле, Василиј Кандински, Франк Лојд Рајд и многу други.

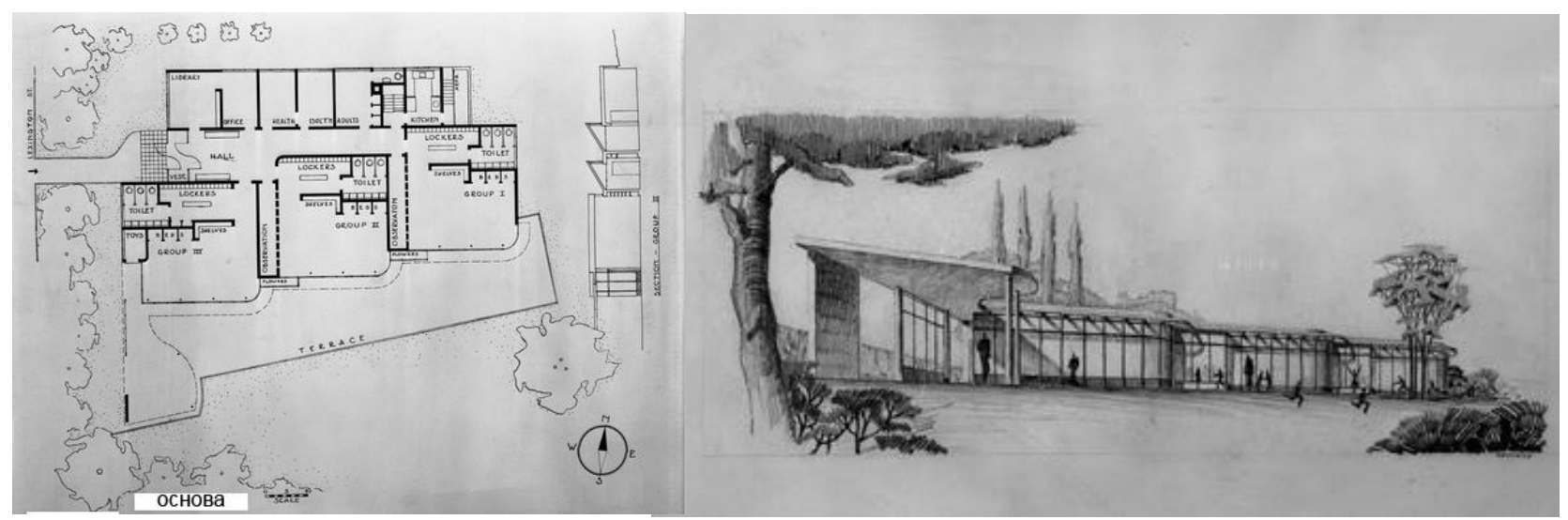

СЛИКА $2^{5}$

Проектот на Валтер Гропиус за детската градинака во Clary Peabody Trust

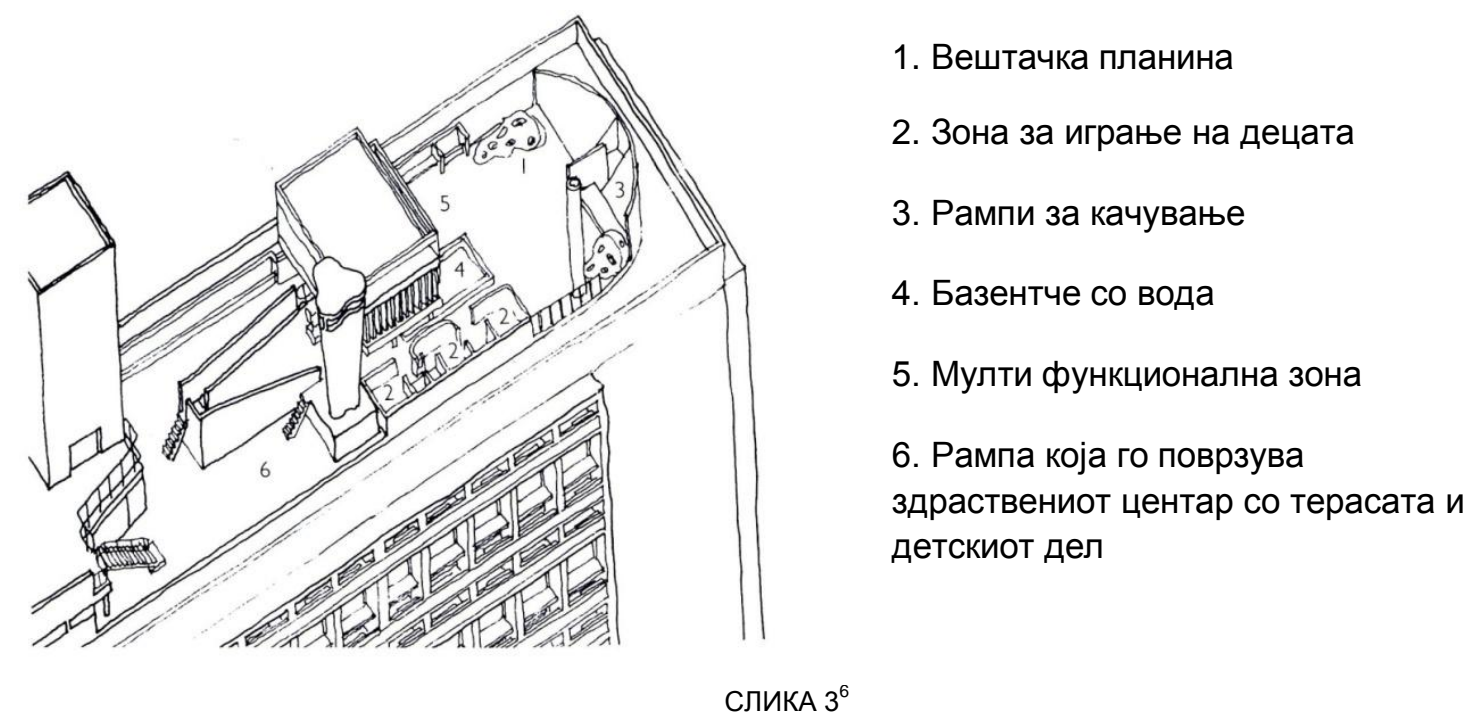

Проектот на Ле Корбизие

\footnotetext{
${ }^{5}$ Сликата е преземена од http://via.lib.harvard.edu/via/deliver/deepcontent?recordld=HUAM219362

${ }^{6}$ Сликата е преземена од Dudek Mark. Kindergarten architecture. Second Edition. London: Spon Press, 2000. Pg. 34
} 


\section{4. ЕДУКАТИВНИОТ ПРОЦЕС ВО РЕПУБЛИКА МАКЕДОНИЈА И ОРГАНИЗАЦИОНАТА ПОСТАВЕНОСТ НА ПРЕДУЧИЛИШНИТЕ УСТАНОВИ}

\section{1. Категоризација на предучилишните установи}

Предучилишните установи во Република Македонија се поделени во две целини:

1. Јасли во кои се опфатени деца од шест месеци до две години, поделени во мала јаслена група (6- 18 месеци) и голема јаслена група (18- 24 месеци).

2. Градинки во кои се опфатени деца од две до шест години, поделени во мала група (2- 4 години), средна група (4- 5 години) и голема група (5- 6 години).

3. Комбинирани групи во кои се опфатени деца од 12 месеци до поаѓање во основно училиште.

Во 2008 година, со измена на Законот за основно образование се воведе деветогодишно образование, па децата на возраст од шест до седум години од предучилишните установи се префрлија во основните училишта.

Во Велика Британија и С.А.Д. предучилишната возраст ги опфаќа децата до 5 години. Во Данска и Шведска во предушилишните установи престојуваат деца од третата до петтата година, во Германија Австрија и Србија до седмата година, додека во останатите земји од Европа до шестата година.

\section{2. Стандарди за капацитетот на предучилишните установи}

Според стандардите кои се пропишани во Законот за заштита на децата ${ }^{7}$, потребна минимална површина на земјиштето е 25 м $^{2}$ по дете, а по исклучок не помалку од $15 \mathrm{~m}^{2}$, ако во непосредна близина на објектот има развиена зелена површина. Поранешните $\mathrm{JyC}^{8}$ стандарди предвидуваат минимална површина на земјиштето по дете од $30 \mathrm{~m}^{2}$ и тоа површина од најмалку $15 \mathrm{~m}^{2}$ за игралиште, а оптимална површина од $50 \mathrm{~m}^{2}$. Со ова се обезбедува доволен простор за детски игралишта и слободен простор, односно остварување на биолошки услови за правилна циркулација на ветерот и осончаност на објектот. Нашиот стандард ни од далеку не ги задоволува стандардите од поранешниот ЈУС стандард, како и европските и светските стандарди. Реалната ситуација во која се наоѓаат предучилишните установи во РМ, неможноста да бидат соодветно обновени или да се изградат нови објекти, доведува до прифаќање

\footnotetext{
${ }^{7}$ Службен весник на Република Македонија бр. 98, 2000 година и бр.65, 2004 година.

${ }^{8}$ Savetovanje "Programiranje, proektovanje I opremanje objekta za decu". Zagreb, 1973.
} 
на стандарди кои ни од далеку не ги исполнуваат основните параметри, односно се носат стандарди, зависносно од тоа каква е моменталната состојба на објектот. Сето ова доведува до момент на импровизации, со влијание врз правилниот развиток на детето при престој во предучилишните установи.

Просторијата каде престојуваат децата или занималната преставува мултифункционална единица, чија површина е однапред определена со одреден број на деца кои можат да престојуваат. Според Правилникот за стандарди и нормативи за вршење на дејноста на детски градинки ${ }^{9}$ на ниво на Република Македонија, просториите за престој на децата треба да зафаќаат површина од најмалку $40 \mathrm{~m}^{2}$ и височина од 2,8 м. Одвоено, јаслените простории треба да се со димензија од $3,5 \mathrm{~m}^{2}$ по дете, а просториите за децата од 2 - 6 години од 2,4 $\mathrm{m}^{2}$.

Пооделено според групи детските јасли треба да се поделени во две групи и тоа:

\begin{tabular}{ccc}
\hline Група & Возраст & Број на деца \\
\hline I група & $6-18$ месеци & $8-10$ \\
II група & $18-24$ месеци & $10-12$ \\
\hline
\end{tabular}

Табела 1 - број на деца во јаслени групи

Детските градинки за разлика од јаслените групи прифаќаат поголем капацитет на деца. Поделени се на следниов начин:

\begin{tabular}{ccc}
\hline Група & Возраст & Број на деца \\
\hline Мала & $2-3$ години & $12-15$ \\
Средна & $3-4$ години & $15-18$ \\
Голема & $4-6$ години & $20-25$ \\
\hline
\end{tabular}

Табела 2 - број на деца во детските градинки

Странските нормативи за минималните големини на просториите во кои престојуваат децата во секоја земја се различни и тоа од $1,5 \mathrm{~m}^{2}$ до $10 \mathrm{~m}^{2}$ површина по дете.

\footnotetext{
${ }^{9}$ Службен весник на Република Македонија бр. 35, 2009 година стр. 4
} 


\begin{tabular}{|c|c|c|c|c|}
\hline земја & возраст & број на деца & $\begin{array}{c}\text { површина } \mathrm{m}^{2} \\
\text { по дете }\end{array}$ & $\begin{array}{l}\text { големина на } \\
\text { просторија м }\end{array}$ \\
\hline \multirow[b]{2}{*}{ Австрија } & до 3 години & 12 до 18 & & \\
\hline & 3 до 7 години & 25 до 30 & 2.00 & 60 \\
\hline \multirow[b]{2}{*}{ Италија } & до 3 години & $\max 20$ & 10.00 & 200 \\
\hline & 3 до 6 години & $\max 40$ & 7.50 & 300 \\
\hline \multirow{2}{*}{ Германија } & до 3 години & $\max 15$ & 3.00 & 45 \\
\hline & 3 до 7 години & $\max 35$ & 2.00 & 70 \\
\hline Данска & 3 до 5 години & 20 & 2.00 & 40 \\
\hline Белгија & до 6 година & $\max 32$ & 1.50 & 48 \\
\hline Франција & до 6 година & $\max 40$ & 1,50 & 60 \\
\hline Шведска & 3 до 5 години & $\max 15$ & 3.50 & 53 \\
\hline Швајцарија & до 6 година & $\max 25$ & 3.00 & 75 \\
\hline $\begin{array}{l}\text { Велика } \\
\text { Британија }\end{array}$ & до 5 година & $\max 15$ & 2.30 & 35 \\
\hline \multirow{2}{*}{ Србија } & до 3 години & 8 до 12 & $\min 3.30$ & 40 \\
\hline & 3 до 7 години & 16 до 24 & $\min 2.50$ & 60 \\
\hline
\end{tabular}

Табела 3 - површина на просторот по број на едно дете

\section{3. Големина на предучилишните установи}

Во предучилишните установи бројот на јаслените групи и детските градинки ја диктираат големината на објектот. Тие можат најчесто да бидат:

1. Предучилишните установи со мал капацитет, во чија содржина влегуваат најмалку три, а најмногу 10 групи. Исклучок од ова прават пренаменети објекти од различен вид, најчесто станбени единици во детски градинки, каде се дозволени минимум две групи.

2. Предучилишните установи со среден капацитет од 10 до 20 детски групи.

3. Предучилишните установи со голем капацитет со над 20 детски групи.

Во Македонија најзастапени се предучилишните установи со мал и среден капацитет на детски групи. Не се препорачува градење на предучилишни установи со голем капацитет. Иако се намалува инвестицијата на вложување

${ }^{10}$ Dudek, Mark. Kindergarten architecture. Second Edition. London: Spon Press, 2000. Pg. 3-4 
во објектот и неговото одржување по глава на дете, големата концентрација на деца неповолно делува на нивната социјализација и одвивање на воспитно образовната дејност.

\section{4. Статистички податоци за предучилишните установи}

Според статистичките проекции на Државната агенција за статистика на Република Макединија во 2009 година има 22213 деца кои се опфатени со некоја од формите на предучилишно образование. Изразено во проценти изнесува околу $14 \%$ од вкупната популација на деца. Во Скопје, бројот на деца кои посетуваат предучилишна установа изнесува 10 473, односно половина од вкупниот број во целата држава.

Во општина Центар предучилишна настава во 11 објекти посетуваат 1657 деца.

\begin{tabular}{cccccccc}
\hline вкупно & $\begin{array}{c}\text { до 1 } \\
\text { година }\end{array}$ & 1 година & 2 години & 3 години & 4 години & 5 години & 6 години \\
\hline 1657 & 38 & 97 & 286 & 254 & 419 & 406 & 157 \\
\hline
\end{tabular}

Табела 4 - Деца сопред возраст во општина Центар ${ }^{11}$

Општина Центар, споредено со другите општини во Град Скопје, има најмногу деца по глава на жител, кои престојуваат во предучилишните установи.

\begin{tabular}{lrrr}
\hline \multicolumn{1}{c}{ Општина } & $\begin{array}{c}\text { вкупен број } \\
\text { на жители }\end{array}$ & $\begin{array}{c}\text { број на деца } \\
\text { што } \\
\text { посетуваат } \\
\text { П. У. }\end{array}$ & $\begin{array}{c}\text { \% на деца од } \\
\text { вкупното } \\
\text { население }\end{array}$ \\
\hline Аеродром & 72007 & 1853 & $2.57 \%$ \\
Бутел & 36154 & 681 & $1.89 \%$ \\
Гази Баба & 72617 & 1393 & $1.92 \%$ \\
Горче Петров & 41634 & 532 & $1.23 \%$ \\
Карпош & 59666 & 2049 & $3.43 \%$ \\
Кисела Вода & 57236 & 1330 & $2.32 \%$ \\
Центар & 45412 & 1657 & $3,65 \%$ \\
Чаир & 64773 & 978 & $1.51 \%$ \\
\hline
\end{tabular}

Табела 5 -процент на деца според скопските општини ${ }^{12}$

\footnotetext{
${ }^{11}$ Државен завод за статистика на Република Македонија. Јавни установи за згрижување и воспитание на деца- детски градинки, 2009.
} 
4.5. Организација на предучилишните установи според дневниот престој

Предучилишните установи според времетраењето остваруваат програми за:

1. Целодневен престој, каде децата престојуваат во времетраење од 8 до 11 часа дневно. Овој облик на престој има воспитнообразовен и згрижувачки карактер, пред се за оние деца чии родители се вработени.

2. Полудневен престој, кој трае од 4 до 6 часа дневно кој за разлика од класичниот целодневен престој, децата престојуваат според потребите на родителот или афинитетот на самото дете.

3. Скратени програми кои траат од 240 до 600 часа годишно, односно престој на децата од неколку саати два-три пати неделно, кој има улога на социјализација или едукација на децата.

Начинот на организирање на дневниот престој во предучилишните установи влијае врз дефинирањето на просторот каде престојуваат децата. Активностите кои ги извршуваат во зависност од времето колку се присутни во просторијата, не зависи само на димензиите туку и на фуннцционалната организација, па колку подолго престојуваат, толку повеќе функции обавуваат. Просторот е уреден според потребите на децата кои ги извршуваат, зависно од должината на престојот.

\footnotetext{
${ }^{12}$ Државен завод за статистика на Република Македонија. Статистички годичник на Република Македонија, 2010.
} 


\section{5. ДОСЕГАШНИ СОЗНАНИЈА ВО ИСТРАЖУВАЧКАТА ОБЛАСТ}

\section{1.Антропометриска анализа потребна во предучилишните установи}

При проектирање и дизајнирање на објекти и мебел секогаш како репер треба да се земат човековите мерки, за да може просторот целосно да биде фрункционален, а мебелот ергономичен. Доколку не ја следиме антропометријата и не ја примениме правилно во просторот, може да дојде до дисфункционален простор и мебел кој нема да биде корисен за употреба. При проектирањето на детски установи како примарна се зема мерката на децата. Во предучилишните установи скоро секогаш, јаслените групи и детските градинки се во ист објект, па затоа се земаат мерките на децата од 6 месеци па до 6 години, односно до пред тргнување во училиште. Нормално целиот објектот нема да се гради по мерката на децата, затоа што природно во него има циркулација и на возрасни луѓе, вработени лица и родители. Мерките на децата треба да се запазат во оние простории каде што тие престојуваат, односно мебелот кој го користат.

Детските мерки се многу помалку обработени за разлика од мерките на возрасните, па затоа ќе бидат обработени некои основни мерки како висина и висина на колена во седечка положба. Овие две мерки можат да бидат појдовни при проектирањето на мебел.

\begin{tabular}{lcc}
\hline & Висина & \\
\hline Возраст & Момче & Девојче \\
\hline години & $56 \mathrm{~cm}$ & $51 \mathrm{~cm}$ \\
$\mathbf{1}$ година & $76 \mathrm{~cm}$ & $71 \mathrm{~cm}$ \\
\hline $\mathbf{2}$ години & $86 \mathrm{~cm}$ & $86 \mathrm{~cm}$ \\
$\mathbf{3}$ години & $97 \mathrm{~cm}$ & $97 \mathrm{~cm}$ \\
$\mathbf{4}$ години & $102 \mathrm{~cm}$ & $102 \mathrm{~cm}$ \\
$\mathbf{5}$ години & $112 \mathrm{~cm}$ & $107 \mathrm{~cm}$ \\
\hline $\mathbf{6}$ години & $128 \mathrm{~cm}$ & $126 \mathrm{~cm}$ \\
\hline
\end{tabular}

Табела 6 - висина на предучилишни деца ${ }^{13}$

\footnotetext{
${ }^{13}$ Lueder, Rani \& Valerie J. Berg Rice. Ergonomics for children. Designing products and places for toddlers to teens. New York: Taylor \& Francis, 2008. Pg. 664.
} 


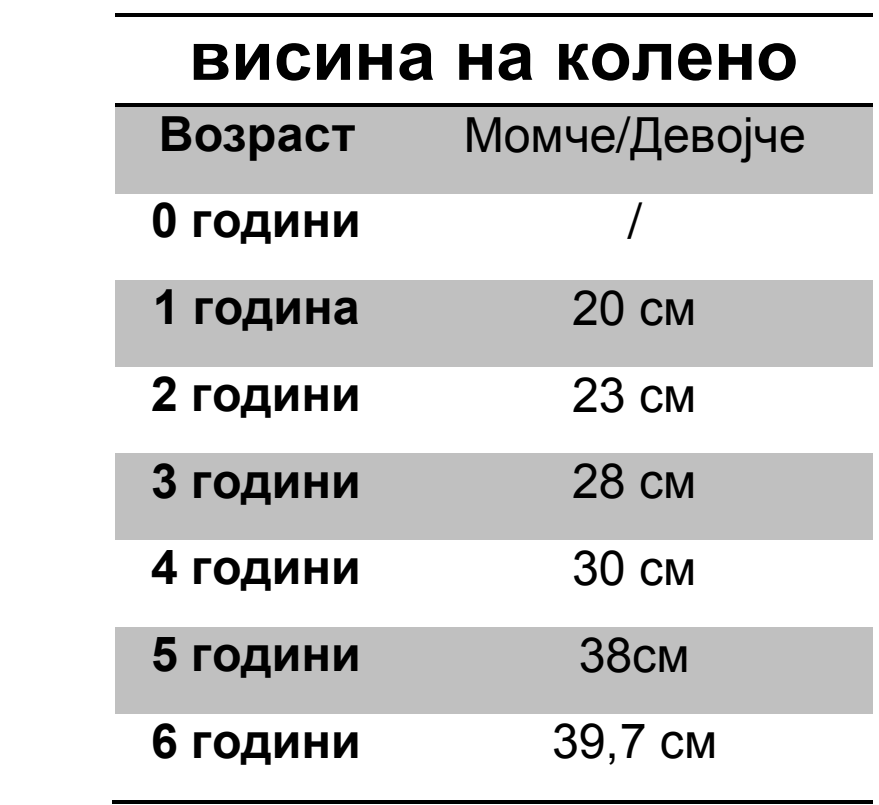

Табела 7 - висина на колена кај предучилишни деца ${ }^{14}$

\section{2.Типологија на предучилишните установи}

Предучилишните установи претставуваат објекти во кои се згрижуваат децата и се врши воспитно-образовна дејност и како такви треба да ги исполнуваат сите барања за кои се наменети. Поради должината на престојот на децата во предучилишните установи, повеќе од 12 часа, тие треба да ги имаат сите содржини потребни за непречено и нормално одвивање на активностите и секојдневните потреби на децата.

Предучилишните објекти во поглед на спратноста може да бидат приземни или објекти со приземје и кат. Објектите на приземје имаат предност пред објектите со приземје и кат. Тие обезбедуваат поголемата отвореност кон надворешноста. Од секоја занимална може директно да се излезе кон дворот, без притоа да има разлика во висината на теренот и самиот објект, со што се намалува можноста од евентуална повреда на децата. Приземните објекти обезбедуваат поголема сигурност бидејќи е изземена вертикалната комуникација, а во исто време се обезбедува и поголем продор на дневна светлина доколку се постават плафонски прозори. Објектите на приземје и кат се градат доколку големината на парцелата не дозволува приземна градба. Обично на катот се сместени јаслените групи, како и сите пропратни простории.

Организационо предучилишните објекти може да се поделат на:

\footnotetext{
${ }^{14}$ Lueder, Rani \& Valerie J. Berg Rice. Op. cit., 665
} 
- Простории каде престојуваат децата, за секоја возрасна група одделно,

- Заеднички простории за децата,

- Административни простории,

- Економско-технички простории,

- Комуникациски простории.
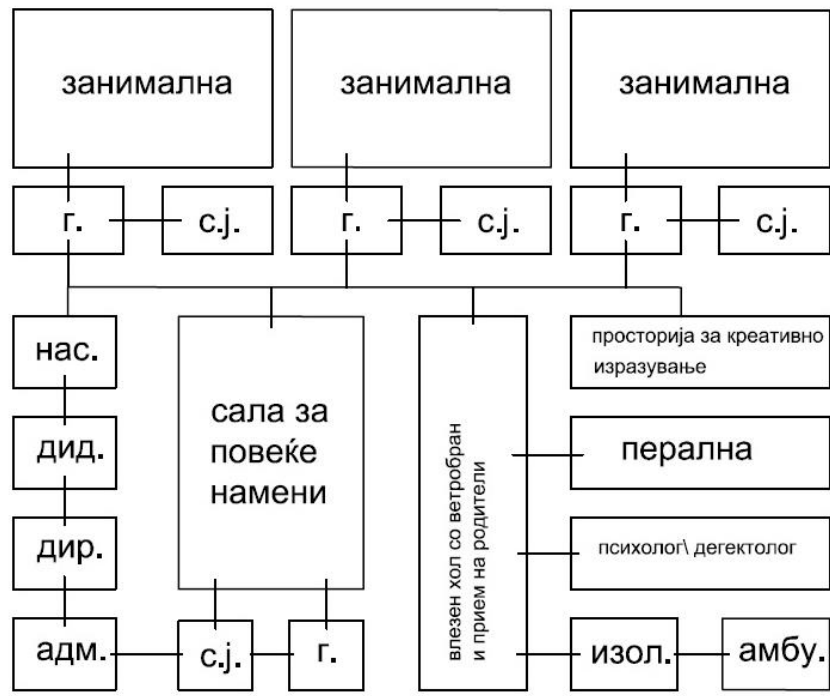

г. - гардероба

с.j. - санитарен јазол

нас - просторија за наставнички

дид. - дидактика

дир. - директорка

адм .- канцеларија за

административни работници

изол. - просторија за изолација

амбу. амбуланта

СЛИКА 4

Просторна структура на предучилишен објект

\subsection{1 Простории каде престојуваат децата}

Просториите за деца ги содржат следните целини: занимална, гардероба, санитарни јазли, тријажа и тераса.

Просториите каде престојуваат децата или занималните, преставуваат целина во која приоритетот е фокусиран во строго кодифицирана организација. Секоја соба има сопствена бања, гардероба, простор за играње, спиење како и место за одвивање на образовниот процес. Затоа што просторот е изразен пред се како серија од квази-функционални зони и нивната површина е однапред лимитирана со одреден број на деца кои можат да престојуваат, треба да биде испроектиран на начин кој ќе овозможи беспрекорна функција. Друга битна особина која ја детерминира просторната организација е возраста на децата, поделена во групи, секоја со свои навики и потреби. Ова е опсег на активности кои се толку цврсто пропишани, со што на архитектите и дизајнерите им ја ограничува можноста за импровизација на сметка на нивната креативност. Тие секогаш треба да го задоволат просторот од педагошки и 
фрунццинален аспект за правилен психо-физички развој. Занималните треба да обезбедуваат простор за групна и индивидуална работа. Активностите кои се одвиваат во занималните може да се поделат во неколку групи, како: практични активности - миење, облекување, јадење, спиење; обични активности - цртање, моделирање, конструирање; слободни активноси трчање, скокање и други фризички активности; активности во група - пеење, глумење, слушање на музика. Според правилникот за стандардите и нормативите за вршење на дејноста на детските градинки во Република Македонија, занималните треба да се со површина од најмалку $40 \mathrm{~m}^{2}{ }^{15}$

Нераздвоен дел од занималната преставува гардеробата и санитарните јазли за децата. Гардеробата е простор кој ги поврзува просториите за комуникација со занималната, а притоа преставува хигиенски филтер помеѓу надворешноста и занималната. Гардеробата првенствено служи за одлагање на облеката при доаѓањето во предучилишниот објект. Видот на гардеробата зависи од концептот на архитектонската основа на објектот. Таа може да биде концентрирана, каде се одлага облеката во посебен простор наменет за таа цел и претставува преоден дел од ходникот кон занималната и разредена гардероба, каде орманчињата се поставени долж просторот за комуникација. Просечна големина на гардеробата треба да изнесува $12 \mathrm{~m}^{2}$ за една група деца, а доколку ја користат две групи на деца просечната големина треба да изнесува $14 \mathrm{~m}^{2}$. Кај јаслените групи не постои типична гардероба, туку преставува одделна просторија тријажа, каде родителите ги оставаат децата, а понатаму ги преземаат воспитувачите. Тријажата е опремена со мали ормари, маси за преповивање на децата, мијалник, како и маси со прегради. Просечна големина на тријажата изнесува $18 \mathrm{~m}^{2}$.

Санитарните јазли треба да се сместени во посебни простории, кои се поделени во дел за мијалници и дел за тоалетни шољи. Санитарните простории за една група деца треба да изнесуваат $10 \mathrm{~m}^{2}$ или најмалку $18 \mathrm{~m}^{2}$, доколку се користи за две групи на деца. Големината на санитарните елементи треба да ги задоволуваат мерките на децата. Во секоја санитарна просторија треба да има отвор и кон дворот или игралиштето, со што би се овозможила санитарно-хигиенската потреба на децата, додека престојуваат надвор од објектот. Санитарните јазли на јаслените групи треба да имаат маси за повивање на децата, мали кадички со рачни тушеви и мијалници.

\footnotetext{
15 Понатаму во текстот од оваа глава, стандардите и нормите кои се употребени се земени од Правилникот за стандардите и нормативите за вршење на дејноста на детска градинка.
} 

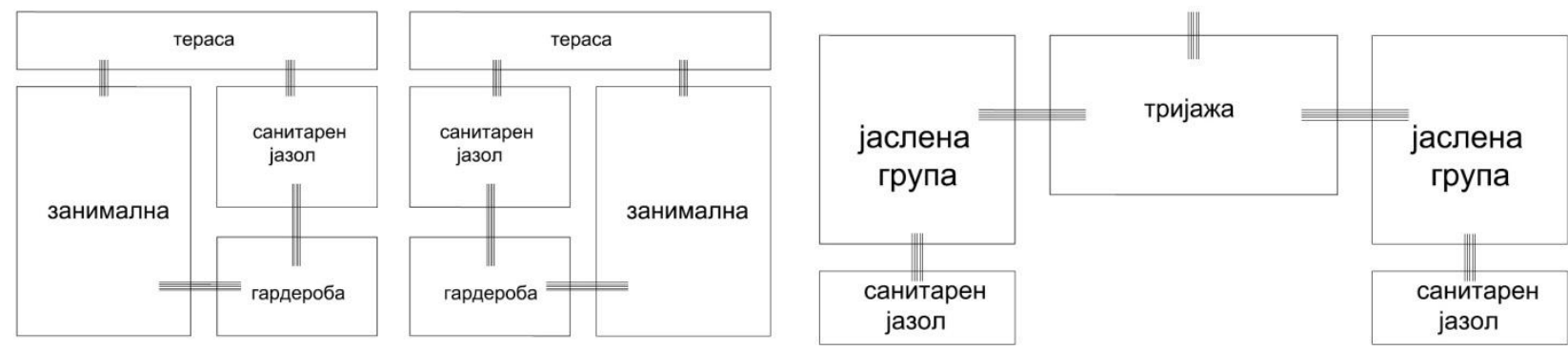

СЛИКА 5

Просторна структура на занималните

\subsection{2 Заеднички простории}

Во оваа група на простории спаѓаaт, просторот за повеќе намени, просторијата за изолација и просторијата за креативно изразување.

Просторијата за повеќе намени најчесто е централно поставена во однос на објектот и претставува место каде се одвиваат групни активности како пеење, приредување на претстави, одржување на некои предавање и друго. Големината на просторијата изнесува по $1 \mathrm{~m}^{2}$ за секое дете, а не помалку од 60 $\mathrm{m}^{2}$. Доколку просторијата за повеќе намени се користи и за фризички активности тогаш димензиите треба да се зголемат до минимум $80 \mathrm{~m}^{2}$. Со просторијата за повеќе намени секогаш оди и помала просторија во која се чуваат реквизити или спортска опрема.

Просторијата за изолација преставува место каде се изолираат болните

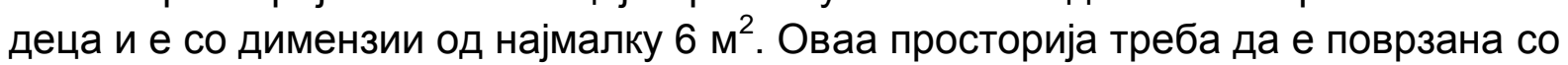
друга просторија во која има постојано присуство на вработено лице.

Просторијата за креативно изразување доколку ја има во предучилишниот објект е наменета како катче во кое се изразуваат креативните активности на децата, како пеење, моделирање и друго. Доколку е присутна оваа просторија тогаш музичките инструменти како клавир може да биде сметен тука. Димензиите на просторијата изнесуваат најмалку $30 \mathrm{~m}^{2}$.

\subsection{3 Административни простории}

Зависно од бројот на вработени условен е $и$ бројот на административните простории. Доколкку предучилишната установа е седиште или матичен објект може да има канцеларија за директорот со димензии од 15 $\mathrm{m}^{2}$ и канцеларијата за администрацијата, за две работни места со $12 \mathrm{~m}^{2}$. Во 
административните простории спаѓаат и заедничката канцеларија на наставничките со големина не помала од $12 \mathrm{~m}^{2}$ и заедничката канцеларија на воспитувачите исто така не помала од $12 \mathrm{~m}^{2}$. Заедничката просторија за стручниот кадар се димензионира во зависност од нивниот број. Тоа е просторија наменета за собирање на наставниците и негователите, одржување на состаноци, консултација и седење. Тука стручните соработници одмораат и се подготвуваат за настава за тековниот ден. Заедничката просторија е составена од дел каде се одлагаат алиштата, простор за седење и работење, како и дел за одмор. Во близина на оваа просторија треба да биде и

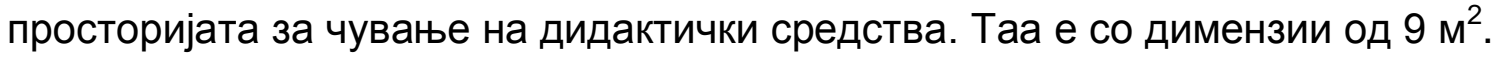

Во зависност од големината на предучилишниот објект, доколку истиот просторно тоа го овозможува треба да има амбулантна просторија за еден лекар со димензија од најмалку $10 \mathrm{~m}^{2}$, две канцеларии за психолог и дефектолог, како и просторија за домаќинот кој се грижи за одржување на објектот. Вработените во административните простории користат посебни санитарни простории, одвоени од оние кои ги користат децата.

\subsection{4 Економско- технички простории}

Економско- техничките простории зафраќаат од 30\% до 35\% од вкупната зфатнина на објектот. Во нив влегуваат кујната, млечната кујна, остава за храна, перална, просторија за пеглање, шиење и складирање на чистата постелнина како и просторија во која е сместена котларницата или друг систем за централно греење.

Престојот на децата од најмалку 8 часа во текот на денот треба да обезбеди доволно храна за нивните потреби, односно најмалку два оброка и една ужина. Поради ова, правилното димензионирање и беспрекорната функционалност на кујните е од особено значење. Храната во предучилишните објекти се подготвува на два начина: Предучилишната установа самостојно ја набавува и подготвува храната во централна кујна и вториот начин е доставување на храна од централна кујна, која се дистрибуира во објектот во дистрибутивната кујна.

Централната кујна треба да обезбедува простор за складирање на овошје, зеленчук и месо, прегради и ормари за чување на лебот. Треба да се обезбеди доволно простор за складирање на залихи потребни за 14 дена. Во кујната треба да се обезбеди груба подготовка, фина подготовка (месо, зеленчук и овошје), топли и ладни јадења, миење на садови, остава за храната и нејзино издавање и тоа:

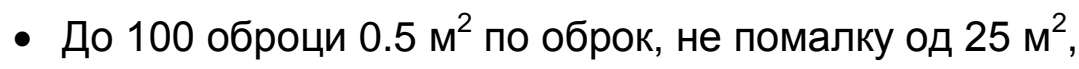


- Од 100 оброци до $1500.3 \mathrm{~m}^{2}$ по оброк.

Доколку кујната подготвува храна која се дистрибуира и за други предучилишни установи, димензиите треба да изнесуваат:

- Од 100 до 300 оброци, $0.25 \mathrm{~m}^{2}$ по оброк,

- Од 300 до 500 оброци, $0.20 \mathrm{~m}^{2}$ по оброк и

- Над 500 оброци, $0.18 \mathrm{~m}^{2}$ по оброк.

Дистрибутивната кујна која ја прифаќа храната од централната кујна односно подготвена во друг објект треба да поседува доволен простор за нејзино прифаќање, место за затоплување и за миење на садови. Димензиите по оброк треба да изнесуваат од најмалку $0.15 \mathrm{~m}^{2}$ и за капацитет од 200 оброка најмалку од $0.38 \mathrm{~m}^{2}$.

Објектите кои поседуваат централна или дистрибутивна кујна треба да имаат придружни санитарни простории со мијалник, тоалетна шоља, туш кабина и гардероба за пресоблекување на вработените.

Млечната кујна преставува просторија која се користи за подготвување на храната за јаслените групи со димензии од најмалку $8 \mathrm{~m}^{2}$. Во млечната кујна треба да се обезбеди простор за подготовка на храна, нејзино одлагање и миење на садови. Кога млечната кујна е на кат треба да има хидраулична рампа поврзана со кујната.

Пералната мора да содржи прегради за сортирање на валканата постелнина, место за поставување на машините за перење, место за нивно сушење, за на крај да бидат испеглани и складирани. Просторијата за перење треба да изнесува најмалку $5 \mathrm{~m}^{2}$, просторијата за пеглање, шиење и складирање треба да биде со димензја не помала од $10 \mathrm{~m}^{2}$.

Просторијата за енергетски постројки во предучилишните објекти служи за сместување на уредите за греење и механичка вентилација.

\subsection{5 Комуникациски простории}

Комуникациските простории треба да бидат јасни, да обезбедат лесна и безбедна комуникација. Влезовите треба да бидат со ветробран и да обезбедат доволен простор за оставање на детските колички. Влезовите се поделени на административен, економски и влез за родителите и деца. Во објектите каде јаслените групи се поделени од групите на детската градинка, влезовите треба да бидат одвоени. Големината на холовите треба да биде со димензии од најмалку 120 см, а доколку се сместени и ормари за гардеробирање димензиите треба да се зголемат до 240 см. 


\section{3.Светло и осветлување на предучилишните установи}

Присуството на дневна светлина во предучилишните установи е од огромно значење во процесот на учење. Таа делува на здравјето на децата, квалитетот на образованието, како и на нормалното функционирање на активностите кои се одвиваат во занималните. Едно истражување изведено на повеќе од 21000 ученици во С.А.Д., во три различни држави Калифорнија, Колорадо и Вашингтон, чија цел била да се воочи како делува дневната светлина врз учениците, довело до следниве резултати ${ }^{16}$ :

Просториите во кои престојуваат децата кои се максимално осветлени, покажуваат поквалитетно и побрзо решавање на тестовите по математика од $20 \%$, а по тестовите за читање од $26 \%$.

Во просторија која има максимално осветлување, децата за $15-23 \%$ подобро ја разбираат материјата предадена на самиот час.

Во просторија која има плафонски прозори, материјата која се предава на самиот час, децата ја усовршуваат за 19 - 20\% подобро.

Науката со поопсежни истражувања дошла до заклучок дека во подобро осветлените простории, во услови на дневна светлина резултатите за совладување на различни вештини се за два до трипати подобри, отколку во простории кои се осветлуваат со вештачка светлина.

Дневната светлина влијае на дваест и четири часовниот биолошки ритам на човекот, односно на регулирање на сложените хемиски и физиолошки процеси. Деноноќниот ритам е од особено значење кај децата, бидејки нивниот сензитивен систем е поосетлив при промена на светлината.

Недостатокот на дневна светлина влијае врз појавата на депресија, замор, раздразливост и недостаток од концентрација. Вакви симптоми се забележани кај многу деца, кои престојуваат во училници или занимални со мал број на прозорски отвори. Децата во овие училници се изложени на многу повеќе немир и раздразливост. За разлика од темните простории, во осветлените, тие се способни да развијат вештина за коцентрација со поголема леснотија. Исто така присуството на светлина влијае на појава на помалку болести ${ }^{17}$.

Присуството на дневна светлина влијае на работата на мелатонинот, хормон кој го создава хипотенузата. Со негова помош се контролира времето за спиење и будење. Во часовите кога спиеме се произведува мелатонин за да обезбеди правилна работа на органите. Количината на производство зависи од

\footnotetext{
${ }^{16}$ Dudek, Mark. School and kindergarten, a design manual. Bazel: Birhäuser, 2008. Pg. 34

${ }^{17}$ ibid
} 
концентрацијата на светлина, а е застапена повеќе кај децата отколку кај возрасните. Оттука, дневната светлина има големо значење за правилниот развој на децата.

Со дневната светлина е поврзана и работата на кортизолот, хормон за стрес. Поголемо присуство во организмот има во текот на денот, а пониско во текот на ноќта. Логично на ова, поголема количина се лачи во лето, отколкуо во зима. Повисоко ниво на кортизол доведува до поголема социјална интеракција, а средно присуство до поголема концентрација и фокусираност. Ова истражување е водено во 90 училишта во Шведска ${ }^{18}$. Нерамнотежата на хормонското присуство влијае на концентрацијата на децата и нивниот раст.

Целосното осветлување на просториите придонесува за позитивен процес во учењето, како и за редовна посетеност во наставниот процес. Децата кои присуствуваат во поосветлени простории помалку отсуствуваат од наставниот процес, за разлика од помалку осветлените простории каде бројот на отсуства е поголем.

Сето ова укажува на фактот дека предучилишните установи мора да бидат правилно проектирани, за да се овозможи правилен раст и развој на децата. За да се обезбеди доволно светлина, предучилишните установи би тебало да бидат градени на еден кат, кои покрај страничните отвори, би имале дополнување и од плафонски прозори.

\subsection{1. Природно осветлување}

Природното осветлување во детските градинки претставува можност за адекватно обезбедување на светлина онаму каде што е потребно, до степен на создавање на визуелен и светлосен комфор, одбегнубајќи ја визуелната непријатност. Светлосниот комфор или правилното осветлување создава чуство на пријатност во просториите каде престојуваат децата, одвивање на секојдневните функции во просториите за кои тие се наменети, го смалува напрегањето на окото, како и заштедува електрична енергија. Дневната светлина се состои од не-насочена дифузна компонента и директна компонента која што е насочена и динамична. Фенестрацијата мора да биде со одредена големина и соодветна позиција, за да одговори правилно на динамичните карактеристики на дневната светлина. Сончевата светлина која претставува директна светлина на дневната светлина е многу динамична. Таа може да биде непријатна, да создава сенки, како и екстремни разлики во

${ }^{18}$ R. Kuller and C. Lindten, 'Health and Behaviour of Children in Classrooms with and without Windows,' in: Journal of Environmental Psychology, No. 12, 1992, p. 305-317. 
осветлувањето во внатрешноста на објектот. Ако не се контролира правилно може да доведе до блескање односно до создавање на визуелна непријатност.

При осветлувањето на просториите каде престојуваат децата треба да се имаат во предвид следните принципи:

- Предучилишните установи треба да се лоцирани на оската истокзапад, при што занималните треба да се сместени на јужната страна.

- Отвори поставени високо на зидот овозможуваат навлегување на дневната светлина подлабоко во просторијата.

- Отвори поставени од две страни ја намалуваат шансата за создавање на визуелна непријатност, појава на сјај и блескање.

- Користењето на индиректна светлина ја намалува појавата на сјај, појава на блесок или друга визуелна непријатност, за разлика од користењето на директна светлина.

- Можност за регулирање на светлината која навлегува во занималните. Кога децата спијат интезитетот на светлината треба да се намали преку венецијанер завеси, платнени завеси или слични помагала, а кога е потребно поголемо количество на светлина, за време на учење или играње, интезитетот на светлината треба да се зголеми преку истите.

\subsubsection{1 Странични прозорци}

Нивото на светлина е поинтезивно во близина на самиот прозорец, а со оддалечувањето од него интезитетот се намалува. Висината на прозорецот во голема мера го диктира продорот на светлината во просторијата. Ниските тавани и премногу долгите занимални можат да се доживеат мачно, поради разликата на светлината која се јавува во близината на прозорецот и крајот на просторијата. Ефективно осветлување може да се добие ако длабочината на занималната, биде до два ипол пати поголема од висината на прозорецот.

За да се добие целосно осветлување на просторијата низ целата нејзина површина, на прозорците се поставуваат таканаречени светлечки полици, преку кои светлината се одбива и се пренесува кон задниот дел на просторијата. Го намалува одблесокот кој се јавува во близината на прозорецот и со тоа се постигнува поуниформирана светлина. 


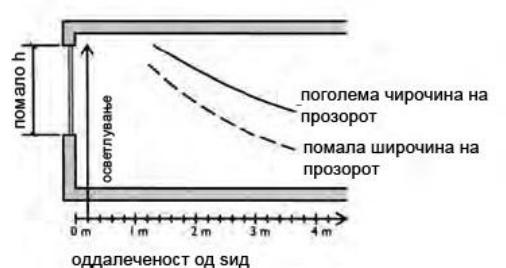

оддалеченост од зид

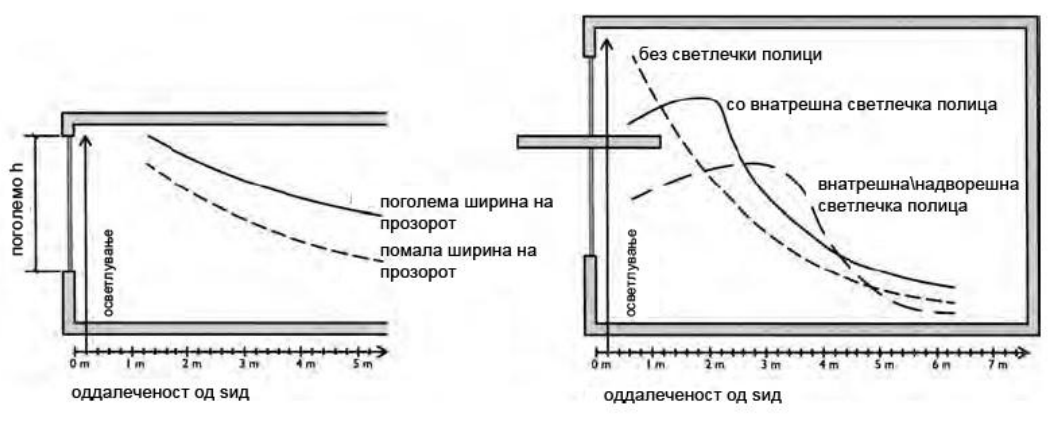

СЛИКА $6^{20}$

Навлегување на светлина при поставување на странични прозорци

\subsubsection{2.Високи прозорци}

Високите прозорци пропуштаат светлина подлабоко во просторијата и создаваат поголема униформирана светлина доколку во просторијата има и страничен прозорец. Светлината која навлегува преку високите прозорци е скоро подеднаква во целата ширина на просторијата, односно не се намалува со одалечување од прозорецот. Односот помеѓу осветлувањето на страничните прозорци и високите прозорци зависи од нивната големина, позиција и висина. Продорот на дневната светлина не зависи само од висината на страничните прозорци, туки и од неговата ширина.
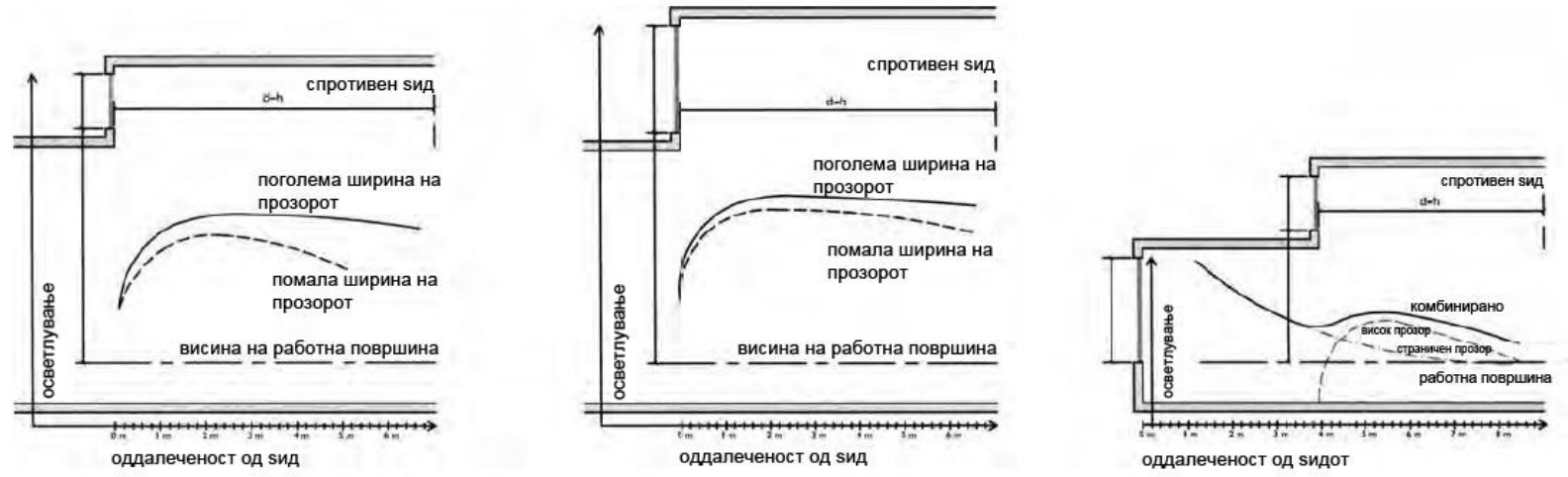

СЛИКА $7^{20}$

Навлегување на светлина при поставување на високи прозорци

\footnotetext{
${ }^{19}$ Dudek, Mark. School and kindergarten, a design manual. Bazel: Birhäuser, 2008. Pg. 36
}

${ }^{20}$ Dudek, Mark, op. cit., 37 


\subsubsection{3. Плафронски прозорци}

Плафонските прозорци се поставуваат на едноспратни објекти. Длабочината на плафонските прозорци и големината на отворот ја диктираат ефикасноста на продирање на дневна светлина. Доколку има само еден отвор во просторијата може да создаде големи разлики во нивото на светлина помеѓу делот под плафонскиот прозорец и остатокот од просторијата. Поставувањето на повеќе од еден плафонски прозорец во просторијата создава поголем визуелен комфор.
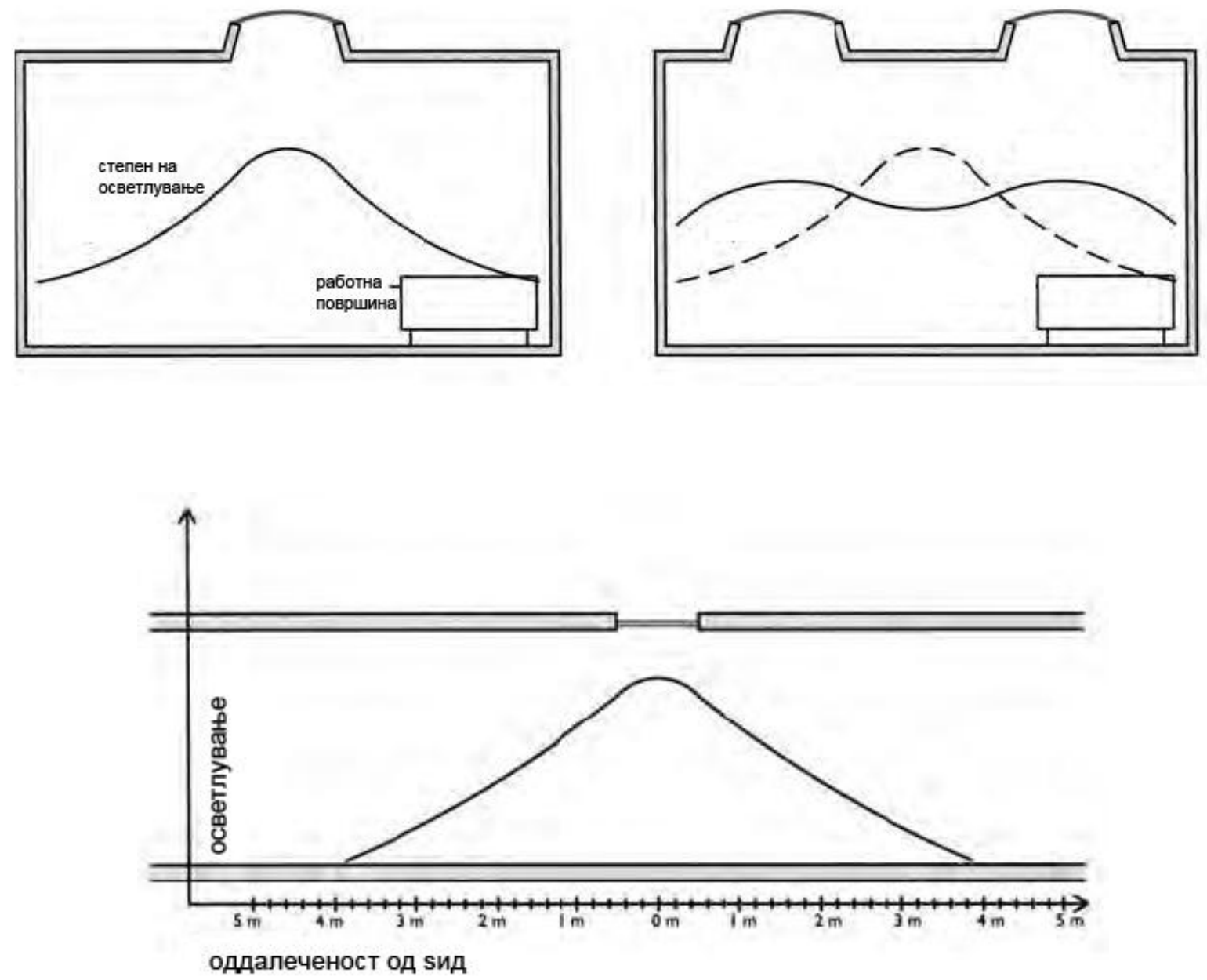

СЛИКА $8^{21}$

Навлегување на светлина при поставување на плафонски прозорци

${ }^{21}$ Dudek, Mark, op. cit., 37 


\title{
5.3.2.Вештачко осветлување
}

Вештачкото осветлување го дополнува природното во случаи кога тоа е намалено односно целосно отсуствува. Вештачкото осветлување треба да ги има истите карактеристики како природното, односно треба да го задоволува интезитетот на осветлување од најмалку $300 \operatorname{lux}^{22}$ и да биде рамномерно за да се спречи појавата на визуелна непријатност. Вештачкото осветлување се состои од светлечки тела кои работат на електрична енергија со различна јачина и интезитет.

Во предучилишните установи, особено во просториите каде престојуваат децата треба да се применува дифузното осветлување ${ }^{23}$, кое овозможува рамномерно распределување на светлината. До пред една декада за најдобар начин на вештачко осветлување се сметаше фрлуоросцентното осветлување, но според некои истражувања во Англија воочено е дека тоа лошо влијае на децата. Адекватна замена е употребата на светлечко тело со полн спектар.
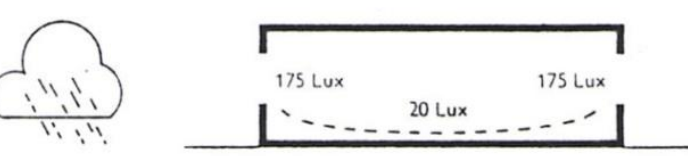

1.
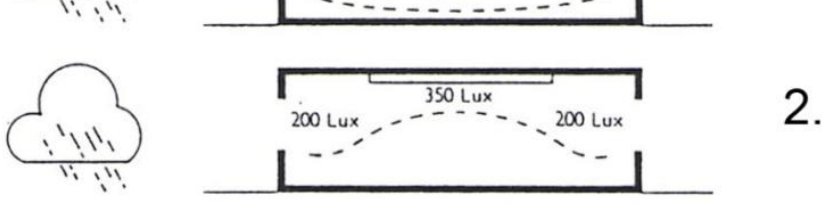

2.
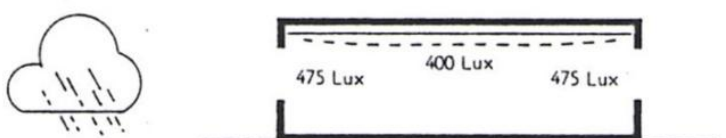

3.
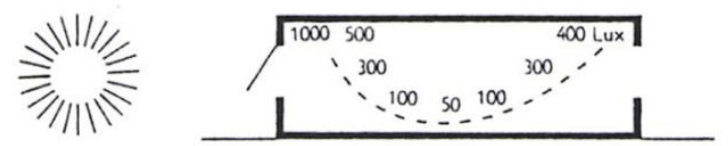

4.
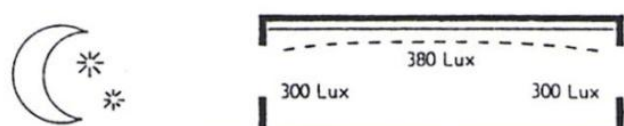

300 Lux 300 Lux

5.

\begin{abstract}
1. облачно време со дожд, 2. Облачно време со дожд и вметната расветла со јачина од 350 lux, поставена во средината на занималната. 3. Облачно време со дожд и вметнета расвлетласо јачина од 400 lux, поставена на целата површина на занималната. 4, Сончево време без облаци. 5. расвета со јачина од 380 lux, по целата површина на просторијата.
\end{abstract}

СЛИКА $9^{23}$

Навлегување на светлината

${ }^{22}$ Dudek, Mark. Kindergarten architecture. Second Edition. London: Spon Press, 2000. Pg. 39

${ }^{23}$ Ivanovič Šekularac, Jelena. Predškolske ustanove I komfor. Magisterski trud. Beograd: Zadužbina Andrejevič , 2000. Str. 59 


\section{4.Топлотни потреби во предучилишните установи}

Топлинските потреби во предучилишните објекти преставуваат еден од главните предуслови за одвивање на нормални активности преку целиот ден. Преку топлинскит комфор се обезбедува топлинска рамнотежа во просториите каде престојуваат децата и се оневозможува појава на непријатно чуство на многу топло или многу ладно. Топлината во предучилишните установи е условена од голем број на надворешни и внатрешни фактори. Надворешни фрактори се географрската местоположба на објектот, климатските услови, ориентацијата на просториите, околината каде е сместен објектот, дали објектот е под влијание на сончевата светлина преку цел ден или е задскриен од околните објекти. Внатрешни фактори кои влијаат на топлинските потреби на објектот се видот на системот за греење, употребата на изолационите матријали како и употребата на материјали на главните конструктивни елементи како зидови, подови и прозорци.

Системот на греење во предучилишните објекти најчесто е изведен преку централно греење со топла вода, пареа или гас. Топлинската енергија се пренесува преку грејни тела радијатори. Тие треба да бидат вон дофат на малите деца и да се избегнуваат остри ивици, за да не дојде до повреда. Топлите радијаторски цевки треба да бидат задскриени или да се поставуваат високо во просторијата каде децата неможат да ги дофатат. Во некои предучилишни објекти радијаторите се обложуваат со радијаторски маски во вид на клупи на кои може да се седи и игра.

Контролата на затопленост на радијаторите за секоја просторија треба да биде одделна и да се менува во зависност од потребата. Доколку се извршуваат фризички активности температурата треба да се намали, а за врема на психичка активност да се зголеми. Греење преку радијаторски грејни тела е најупотребувана форма на греење во Република Македонија. Главен недостаток на ваквиот начин на затоплување е дигање на прашина и нерамномерно загревање на просторијата. Овој вид на греење финански е најисплатлив за инсталирање и одржување.

Во предучилишните установи покрај централното греење преку радијатори, се употребува плафонското и подното греење. Плафонското греење, преку плафонот ги загрева и останатите површини во просторијата, sидовите, подот и мебелот. Топлиот воздух кој настанува од загреаната површина блиску до плафонот, се пренесува со спроведување на топлината преку слоевите на воздух во целата просторија. На овој начин не доаѓа до мешање на топол и ладен воздух како при конвенционалното греење. Позитивни карактеристики се тоа што не настанува струење на воздухот и не се подига прашина во просторијата. Подното греење ја грее подната површина, а потоа целата просторија. Овој начин не подига прашина но мора да го загрее 
просторот конвеционално преку струење на воздухот. Подната температура не смее да биде повисока од $25^{\circ} \mathrm{C}$, бидејќи негативно делува на здравјето на децата. $^{24}$

Во занималните, стандардот за топлински комфор изнесува $22^{\circ} \mathrm{C}$ за јаслените групи и $20^{\circ} \mathrm{C}$ за детските градинки. Во останатите простории температурата треба да се движи од $15^{\circ} \mathrm{C}$ во ходниците, $18^{\circ} \mathrm{C}$ во просториите каде престојуваат вработените, до $25^{\circ} \mathrm{C}$ во просториите за изолација. ${ }^{25}$

На топлината во просториите каде престојуваат децата покрај грејните тела, влијае и топлината на околната површини како што се sидовите и подовите. Ако зидовите се премногу ладни ја намалуваат температурата во просториите, па за да се постигне оптималниот максимум треба да се зголеми јачината на греење, што доведува до додатно финансиско оптеретување. Според ова, детето пријатно ќе се чуствува во просторија која достигнува температурата до $20^{\circ} \mathrm{C}$, а температурата на sидовите е за $2^{\circ} \mathrm{C}$ помала. Во реалноста разликата од $2^{0} \mathrm{C}$ неможе да се постигне, но треба да биде што помала за да не се осети непријатното чувство на „зрачење“ на ладен воздух од sидовите. Температурната разлика на подовите исто така треба да биде за $2^{0} \mathrm{C}$ помала од температурата на просторијата. При избор на подовите треба да се преферира топол под кој не ја губи топлината. Топлиот под е од круцијално значење во детските градинки, затоа што децата поголемиот дел од престојот го поминуваат на подот. Доколку подот е ладен, дел од топлината на детето се губи, што доведува до несакани последици по неговото здравје.

Покрај температурата, за пријатен престој во занималните придонесува и релативната влажност која треба да изнесува од 45\% до $60 \%$.

Струењето на воздухот исто така треба да биде во нормални граници, да не би довело до појава на промаја и непријатно чуство на престој во просторијата. Дозволено струење на воздухот треба да изнесува од 0,07 m/s до $0,01 \mathrm{~m} / \mathrm{s}$. Струење на воздухот се обезбедува и преку вентилација на просторијата на начин што ладниот воздух го потиснува топлиот.

\footnotetext{
${ }^{24}$ Ivanovič Šekularac, Jelena. Predškolske ustanove I komfor. Magisterski trud. Beograd: Zadužbina Andrejevič , 2000. Str. 40

25 ibid
} 


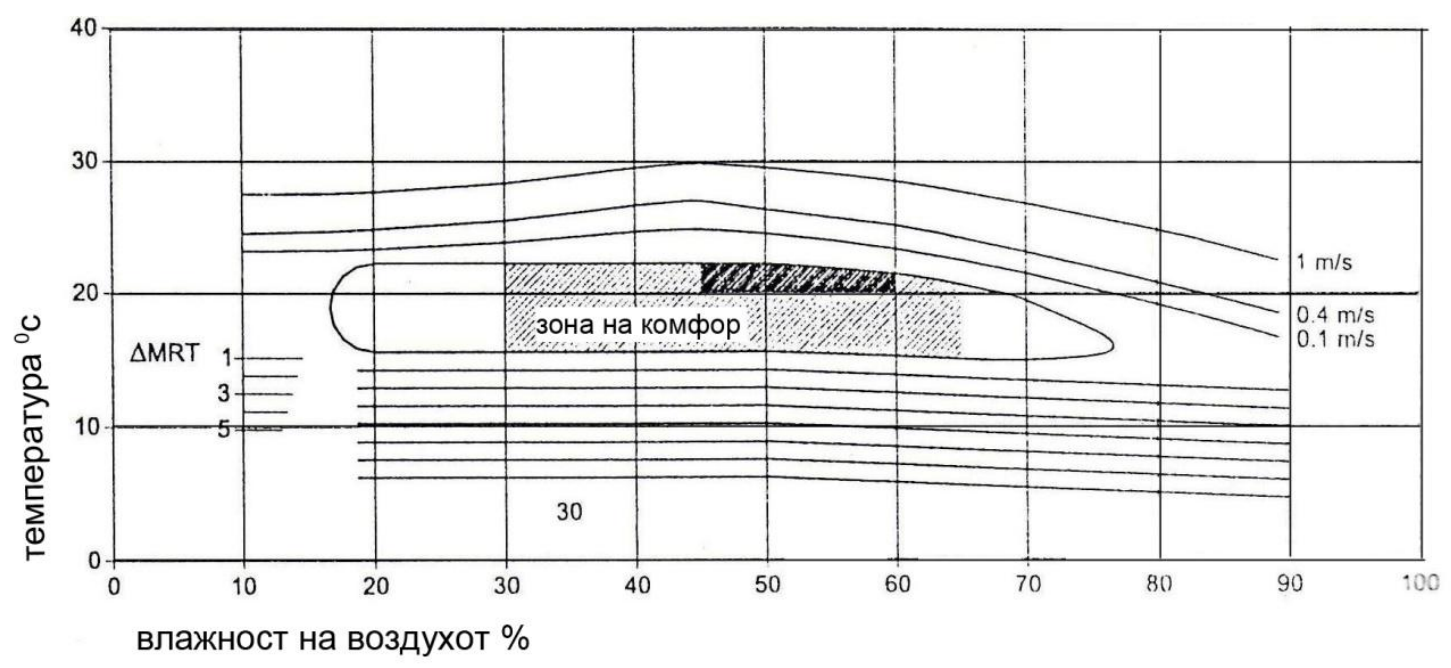

Легенда

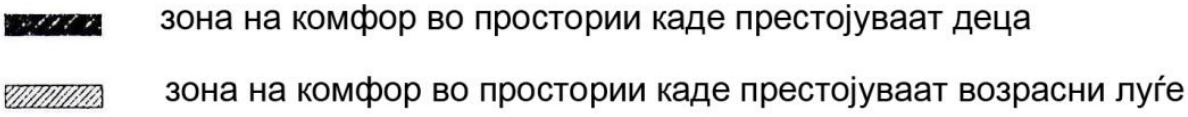

СЛИКА $9^{26}$

График на комфор во простороја каде престојуваат деца

\section{5.Акустични потреби и звучна заштита во предучилишните установи}

Звучната заштита, односно акустичниот дизајн во предучилишните објекти е од големо значење за правилно извршување на воспитнообразовните потреби и правилниот раст и развој на децата. Затоа, при изградба на предучилишни објекти акустичните потреби треба да се земат во предвид во текот на нивната градба, а не во завршната фраза. Се претпоставува дека акустичните потреби во објектот се изведуваат во финалната фраза на изградба, затоа што постои мислење дека карактеристиките на апсорбција на звукот зависат од употребата на внатрешните завршни материјали. Перцепцијата на звукот исто така може да се разгледува индивидуално во зависност од невролошкиот процес на регулација на чуствителноста на увото.

Звукот реагира позитивно или негативно врз човекот, делува на неговите емоции и активира бројни реакции во мозокот. Може да делува смирувачки или да предизвикува страв при ненадејна бучава. На пример познато е дека прекумерно изолирана просторија предизвикува чуство на губење на ориентација во просторот, вознемиреност и замор поради

\footnotetext{
${ }^{26}$ Сликата е преземена од Ivanovič Šekularac, Jelena. Op.cit., 44.
} 
изолираност од се она што се случува надвор. Но во исто време добро изолирана просторија делува смирувачки, доведува до зголемување на концентрацијата и силата ${ }^{27}$.

Многу е тешко да се дефинира квалитетот на акустичност на собите кои се проектираат. Честопати одбегнувајќи ја појавата на ехо, може да дојде до изведба на просторија со прекумерна амортизација, односно загушување на звукот.

Звучната заштита во предучилишните објекти зависи од бројни надворешни и внатрешни фрактори. Бучавата која настанува од надворешни фактори е условена од:

- Местоположбата на предучилишниот објект,

- Оддалеченоста од главните сообраќајници, минимална оддалеченост од $35 \mathrm{M}$,

- Поставеноста во парцелата, самостојно или е опкружена со објекти,

- Организација на внатрешните простории, занималните треба да се свртени кон страна која има помалку бука,

- Опкруженост на предучилишниот објект со зеленило. Дрвјата и грмушките го одбиваат или апсорбираат одредени звучни бранови.

- Оддалеченост од објекти кои произведуваат поголема бука од нормалната, како фрабрики, работилници, железнички станици.

Квалитетот на градбата исто така игра главна улога во звучната заштита на предучилишниот објект. Употребата на соодветна звучна изолација во предучилишните објекти го намалува навлегувањето на бучавата. Градежната столарија која се употребува треба да задоволува барем основни услови за звучна заштита. Во Македонија не постои стандард за употреба на типови на градежна столарија со одредена звучна заштита. Звучната заштита зависи од големината на стаклото, бројот на крилата, квалитетот на изведување на споевите, монтажата и друго.

Внатрешни фактори кои влијаат на создавање на бука во самите предучилишни објекти се активностите на децата (играње пеење, плачење, смеење) како и употребата на материјалите во ентериерот. Буката која настанува од детската активност во занималните може да изнесува од $79 \mathrm{~dB}$ до $85 \mathrm{~dB}$, а во одредени ситуации и до $110 \mathrm{~dB}$. Ова укажува на фрактот дека во предучилишните установи типот на активности треба да бидат усогласени и да се случуваат во исто време.

\footnotetext{
${ }^{27}$ Dudek, Mark. School and kindergarten, a design manual. Bazel: Birhäuser, 2008. Pg. 28
} 
Материјалите кои се употребуват во внатрешноста на просториите се од примарно значење. Типот на подот кој се употребува во занималните треба да го амортизира звукот и да не дозволува да се пренесува во останатите содржини во објектот. Звучната заштита е поголема кога се употребува текстилна завршница или пластична подлога винифлекс, за разлика од дрвените подови. Во холовите, бањите, а понекогаш и во гардеробите, подната завршница е од керамички плочки, поради практични и хигиенски причини. Керамичките плочки имаат иста звучна изолација $R w$ како $n$ текстилната завршница, но звучната пропусливост Lw е значително поголема. Голема улога на звучната изолација придонесува и употребата на пливачки под, како и поставување на мост помеѓу подната завршница и меѓуспратната конструкција.

Материјалите кои се употребуваат во звучната заштита на sидовите се од големо значење за заштита од буката. При ова влијаат повеќе фактори. Подобра звучна изолација на надворешните зидови се постигнува кога се употребува сендвич зид $\mathrm{d}=25 \mathrm{~cm}$, во кој има соодветна изолација, опека и вештачки камен како завршница, за разлика од армирано бетонските зидови. کидови со дебелина од 25 см изведени од опека, изолација и фасадна опека, како и зидови од дурисол блокови $d=30 \mathrm{~cm}$, се поповолни од зидовите од гитер блокови и употребата на соодветна изолација. ${ }^{28}$

Во просториите каде се употребени конкавни или конвексни површини, спречени се груби одбивања на збукот, се избегнува ехото помеѓу паралелните sидови, а се задоволува потребниот износ на апсорпција на повисоките фреквенции. Употребата на тешки материјали доведува до подобра акустика во просторијата каде престојуваат децата, поради помалата моќ на апсорпција. За пригушување на високиот и средниот опсег на фреквенции се користат порозни материјали како минерални или органски влакна. Овој вид на фрреквенција се апсорбира и од луѓето кои се присутни во просторијата и од текстурата на површините во просторијата. Ниските фррекфенции бараат посеопфатен пристап при избор на материјали. Материјалот треба да биде перфориран, зависно од големината на перфорираноста, големината на панелот кој е перфориран и.т.н. Особено корисни материјали за занималните се, не-влакнестите апсорбирачки материјали во микро перфорирана пластика, метални облоги, како и фурнири ${ }^{29}$.

Од формата на собата, зависи и одбивањето на звучните бранови. Конкавните форми го собирааат звукот, а додека конвексните дифузно го распоредуваат. Тесните агли, нишите, просториите поврзани со отвори можат да предизвикаат непријатно одложено одбивање на звукот.

\footnotetext{
${ }^{28}$ Ivanovič Šekularac, Jelena, op. cit., 85

${ }^{29}$ Dudek, Mark. School and kindergarten, a design manual. Bazel: Birhäuser, 2008. Pg. 32
} 
Акустичниот комфор е поголем во занималните кај кои плафонската висина е поголема. Активностите на децата треба да бидат поделени во одредени зони во зависност од бучавата која се појавува. На пример делот каде се изведуваат психички активности читање, цртање, треба да биде издвоена од зоната каде се изведуваат фризички активности или се пее. Затоа препорачливо е да постојат посебни простории каде би се изведувале соодветните активности, музички простории, сала за повеќе намени, како и поставување на посебна просторија во која децата ќе јадат.

\subsection{1.Норматив за звучна заштита на предучилишните установи}

Во предучилишните установи нормативот за дозволена бука не смее да надмине вредноста од $35 \mathrm{~dB}{ }^{30}$ Доколку буката која настанува трае во многу кратки интервали во текот на денот и е неизедначена може да ја надмине и границата на поставениот норматив. За правилна звучна изолација покрај употребата на материјалите, од големо значење е поставенста на инсталациите и погонски простории кои произведуваат поголемо ниво на бука, во близина на занималните. Нормативот кој е поставен во предучилишните згради не влијае само на психо-фризичкиот развој на децата, туки и на вработените во овие објекти. За изведување на непречена работа треба да се обезбеди соодветен акустичен комфор кој го задоволува нормалното одвивање на работните задачи на вработените.

${ }^{30}$ Department for education and skills, creating opportunity, releasing potential, achieving excellence. Bulding Bulletin 93. Acoustic design of schools. London: the stationery office, 2006. Pg. 9 


\section{6. КОМПАРАТИВНА АНАЛИЗА НА ПРЕДУЧИЛИШНИТЕ УСТАНОВИ ВО ОПШТИНА ЦЕНТАР СО ПОСТОЕЧКИТЕ СТАНДАРДИ ВО ПРОЕКТИРАЊЕТО}

Во општина Центар има 11 предучилишни установи, од кои три матични објекти и осум клонови. Предучилишниот матичен објект „13 три клона: „Јасмин“, „Парк“ и „Кукушка“. Матичниот објект „Кочо Рацин“ има исто така три клона: „Бели Мугри“, „Панорама“ и „Наум Наумовски-Борче“, а матичниот објект „Раде Јовчевски-Корчагин“ има два клона: „Пепелашка“ и „Палешка“.

Според државниот завод за статистика на Република Македонија, во општина Центар има 1657 деца кои посетуваат детски установи. Во споредба со другите општини во град Скопје бројот на деца по глава на жител во општина Центар е најголем. Бројот на деца секогаш не е условен само од социјално-економските карактеристики на населението кое ја населува општината, туку и од фрактот дека поголемиот дел од државните институции и компании се наоѓаат токму тука. Така на пример во детските комбинирани установи „Јасмин“ и „Раде Јовчевски-Корчагин“, кои се наоѓаат во строгиот центар, бројот на децата кои се згрижени е поголем од бројот на децата за кои овие објекти се испроектирани. Во предучилишните установи кои се наоѓаат на периферијата на општина Центар, бројот на деца кои се згрижени е помал од проектираниот капацитет. Но, трендот на градење станбени згради во последните неколку години придонесе и во овие објекти бројот на децата да се зголемува.

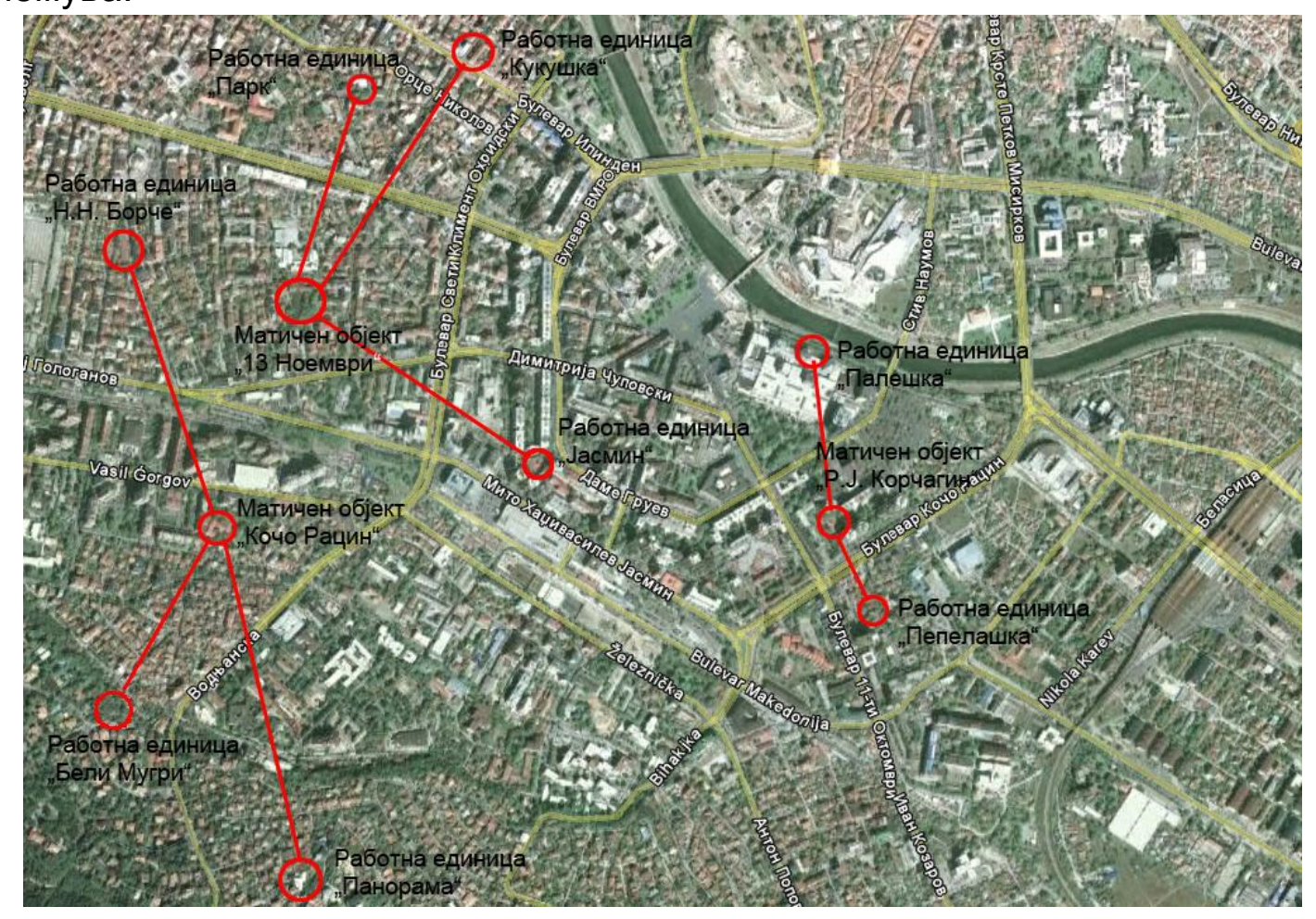

СЛИКА 10 
6.1. Анализа на предучилишните установи во општина Центар со современи тенденции

6.1.1. Предучилишни објекти кои влегуваат во состав на групацијата на установи „13

\subsubsection{1. Комбинирана детска установа „13-ти Ноември“}

Комбинираната детска установа „13 објект на приземје и кат, со сопствен двор. Во објектот можат да се сместат 255 деца од кои две јаслени групи и десет групи на детски градинки. Двете јаслени групи и двете групи на деца од 2 до 3 години се сместени на катот. Јаслените простории зафаќаат површина од $48.80 \mathrm{~m}^{2}$, првата занимална $30.23 \mathrm{~m}^{2}$, а

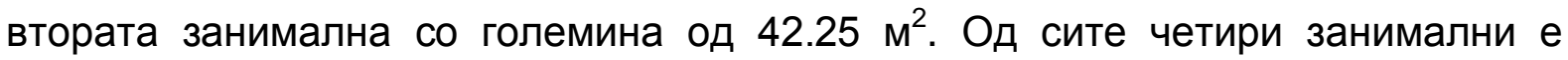
овозможен пристап кон терасите. Секоја занимална има сопствен санитарен јазол, а гардеробите се од разреден тип. На катот е сместена тријажата и простор за прием на родители, млечната кујна, просторија за воспитувачите и персоналот, како и санитарни јазли за вработените.

Влез во објектот има од источната и северната страна. Влезот од северната страна е поделен на влез за јаслените групи, кој преку вертикална комуникација го поврзува катот и влез за во детската градинка. На приземјето се сместени осум занимални од кои пет со големина од $72.40 \mathrm{~m}^{2}$ и една занимална од истиот тип, која дополнително е поделена во просторија за ликовно и музичко изразување. Кај овие занимални гардеробата е разредена односно шкафчињата се поставени по должината на ходникот и една санитарна просторија опслужува две занимални. Позицијата на занималните е

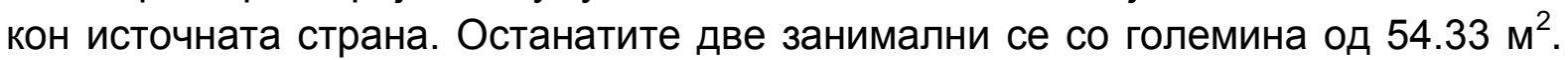
Гардеробата во овие занимални е централизирана и секоја занимална има свој санитарен јазол. Занималните од приземјето имаат пристап кон дворот и местото за играње преку балконски врати. На приземјето е сместена централната кујна, повеќенаменската сала, просторијата за наставничките, канцеларијата на директорот, администрацијата, сметководството, лекарот, како и канцеларијата на социјалниот работник и педагогот. Просторија за перење и пеглање нема во овој објект, па затоа нечистите алишта и постелнина се носат во детската установа „Парк“, каде оттаму чисти се враќаат назад. 


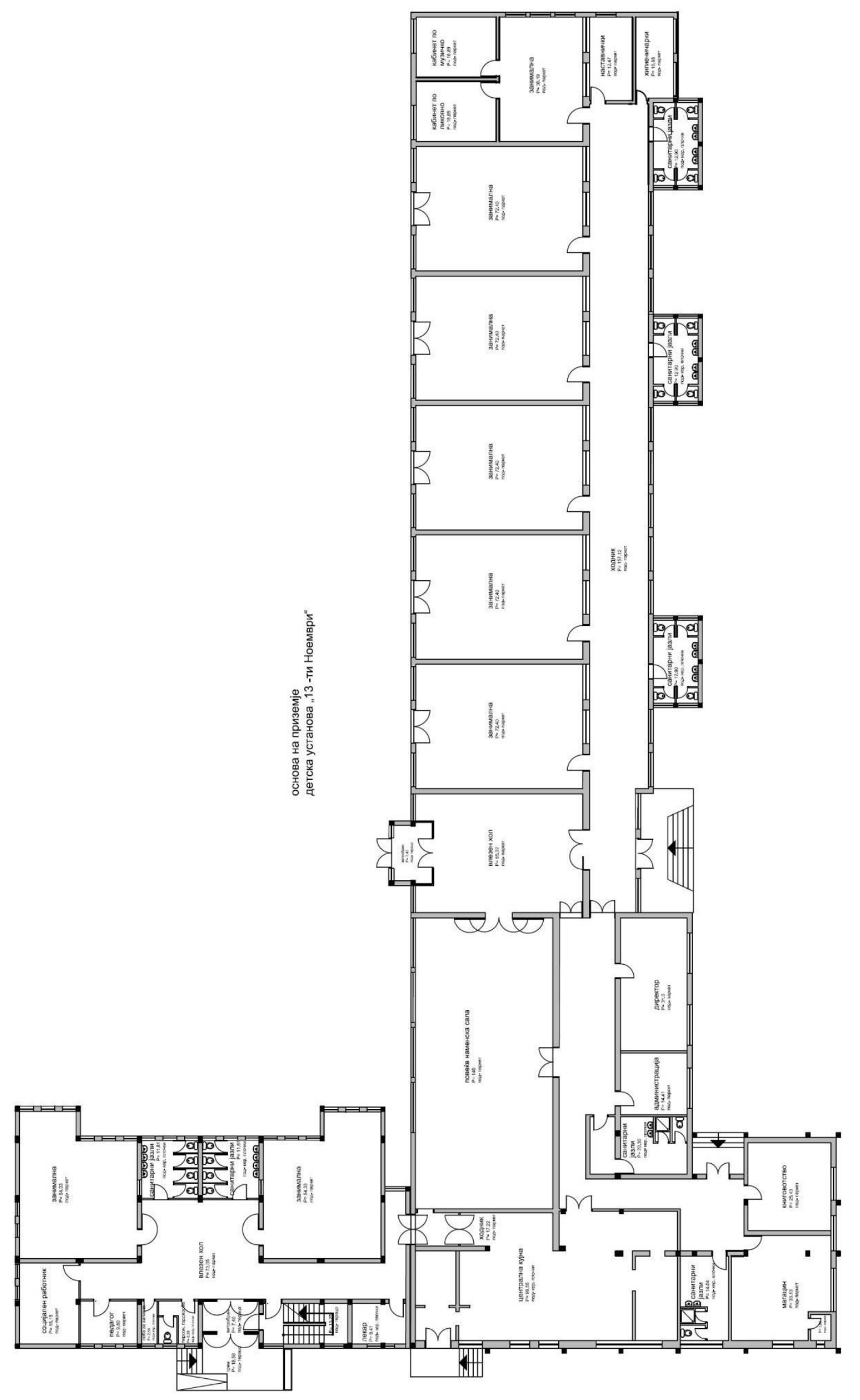


Компаративна анализа на предучилишните установи во општина Центар со современите тенденции во проектирањето и артикулирање на одредени интервенции во просторот како одговор на психо-физичките потреби на децата

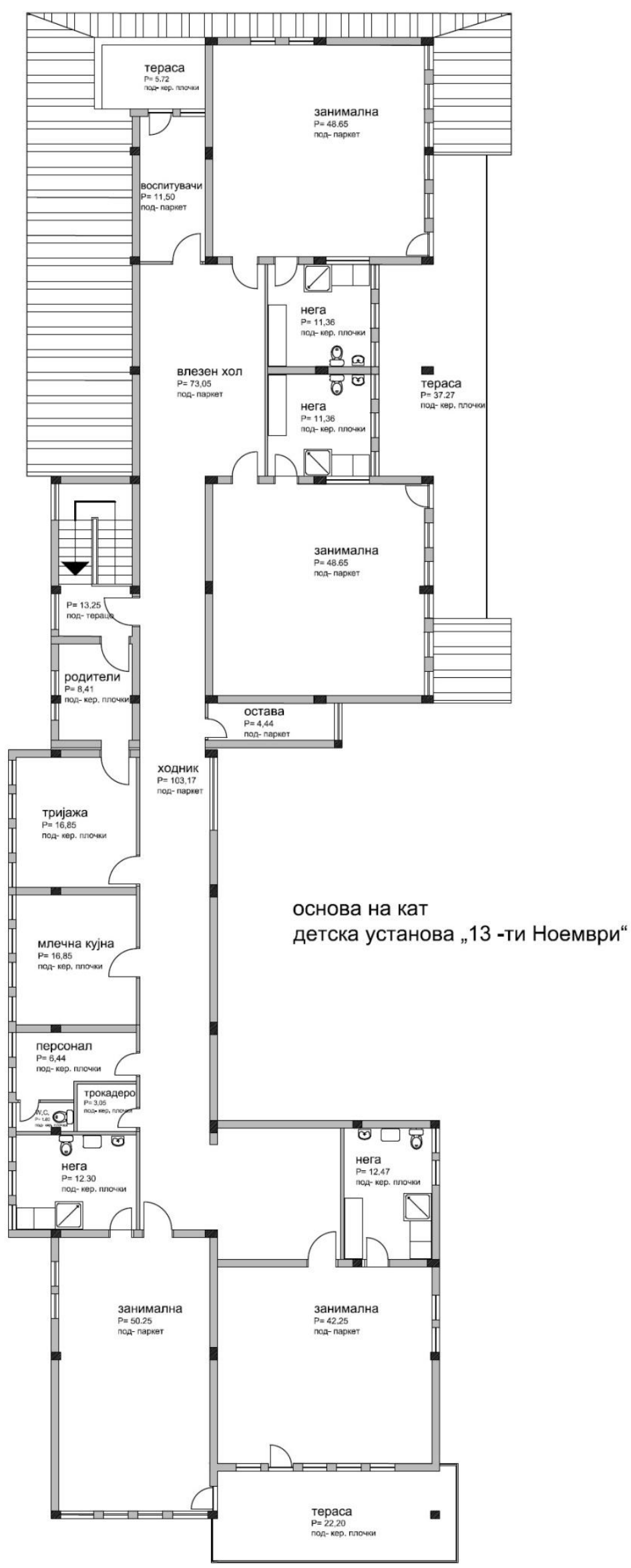




\subsubsection{2. Детска градинка „Кукушка“}

Објектот на детската градинка „Кукушка“ е сместен на улица „Кукушка“ во непосредна близина на Владата на Република Македонија. Тој е индивидуален објект за домување, пренамент во детска градинка. Детската градинка има капацитет да прими 50 деца, во две занимални.

Во објектот се влегува преку ветробран во влезниот хол, кој служи како чекална за родители. Од десната страна на холот се наоѓa просторијата за воспитувачите, каде се пресоблекуваат и две санитарни простории за децата. Во продолжение од холот почнува ходникот со гардероби, преку кои се влегува во двете занимални со големина од $44.75 \mathrm{~m}^{2}$. На крајот од објектот се наоѓа дистрибутивната кујна, магацинот и двете простории за вработените.

\subsubsection{3. Предучилишна установа „Јасмин“}

Предучилишната установа „Јасмин“ е сместена во склоп на градски зид помеѓу два станбени блока, косо поставена. Влезот на градинката е од улица „Даме Груев“ и е поставен на северо западна страна. Капацитет на објектот е 125 деца на возраст од 2 до 6 години, сместени во пет занимални.

Просторната организација во објектот е јасно издвоена по функционални целини на дел каде престојуваат децата, трпезарија која сега е пренаменета во занимална, економски дел и администрација. Влезниот хол е средишно поставен и служи како чекална за родителите. Десно од холот се поставени просториите за администрацијата, канцеларијата на раководителот, канцеларијата за два службеника, просторијата за воспитувачите и лекарот. Од левата страна на холот се наоѓа трпезаријата, пренаменета во занимална и дистрибутивната кујна со сопствен влез. Во средишниот дел на објектот е поставен атриум преку кој се добива природно осветлување во комуникациските простории.

Занималните се поставени на југо-западниот дел од објектот од кои две со големина од $65.13 \mathrm{~m}^{2}$, а две со $67.85 \mathrm{~m}^{2}$. Наспроти занималните се наоѓаат санитарните јазли за секоја занимална по еден, како и гардеробата која е поставена децентрализирано. Во делот на гардеробата каде просторот се проширува, до атриумот, поставен е клавир и истиот служи како простор за музичко воспитание.

Во подрумот е магацинот, пералната која е со многу мал капацитет на перење и засолништето. 
Компаративна анализа на предучилишните установи во општина Центар со современите тенденции во проектирањето и артикулирање на одредени интервенции во просторот како одговор на психо-физичките потреби на децата

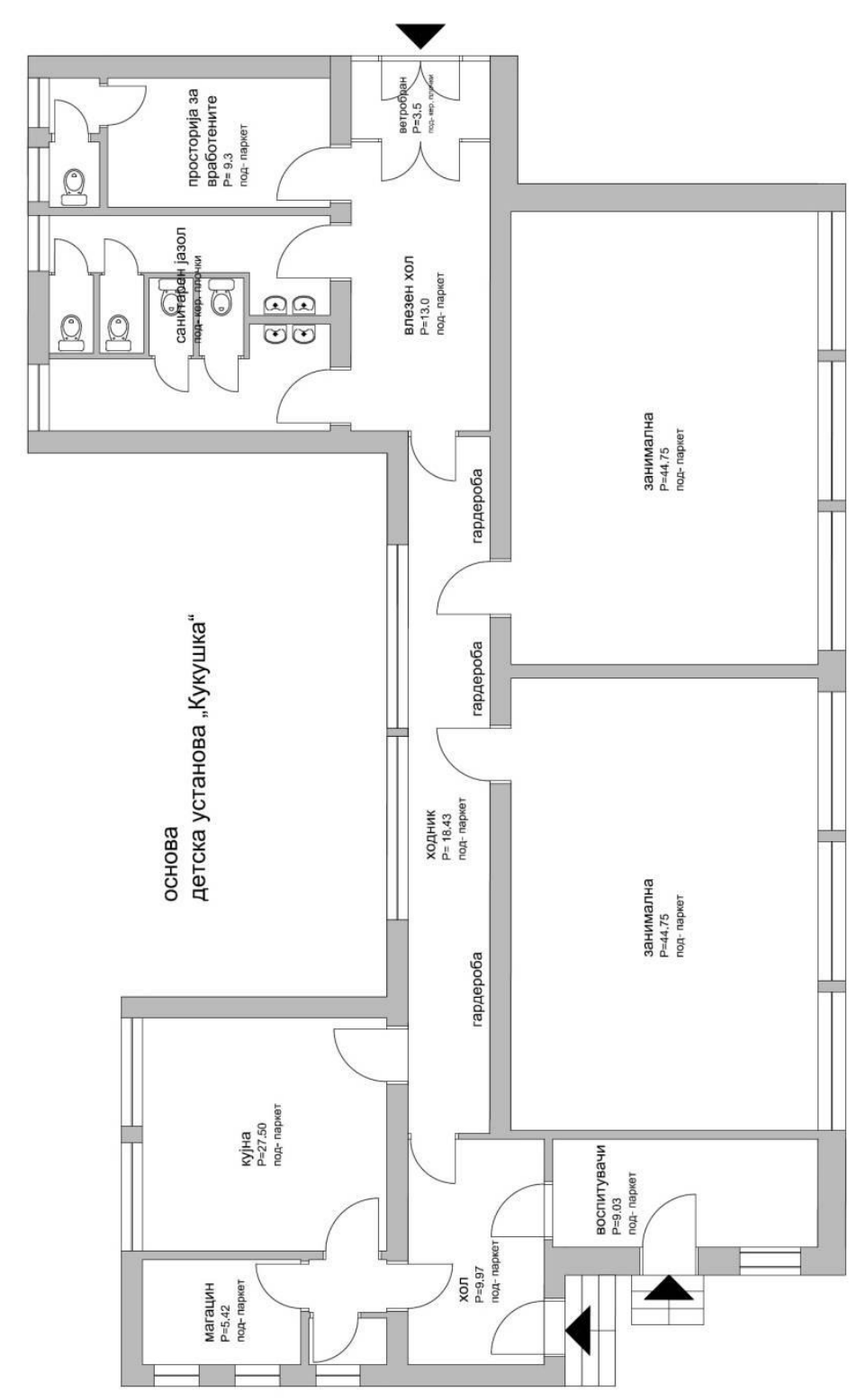




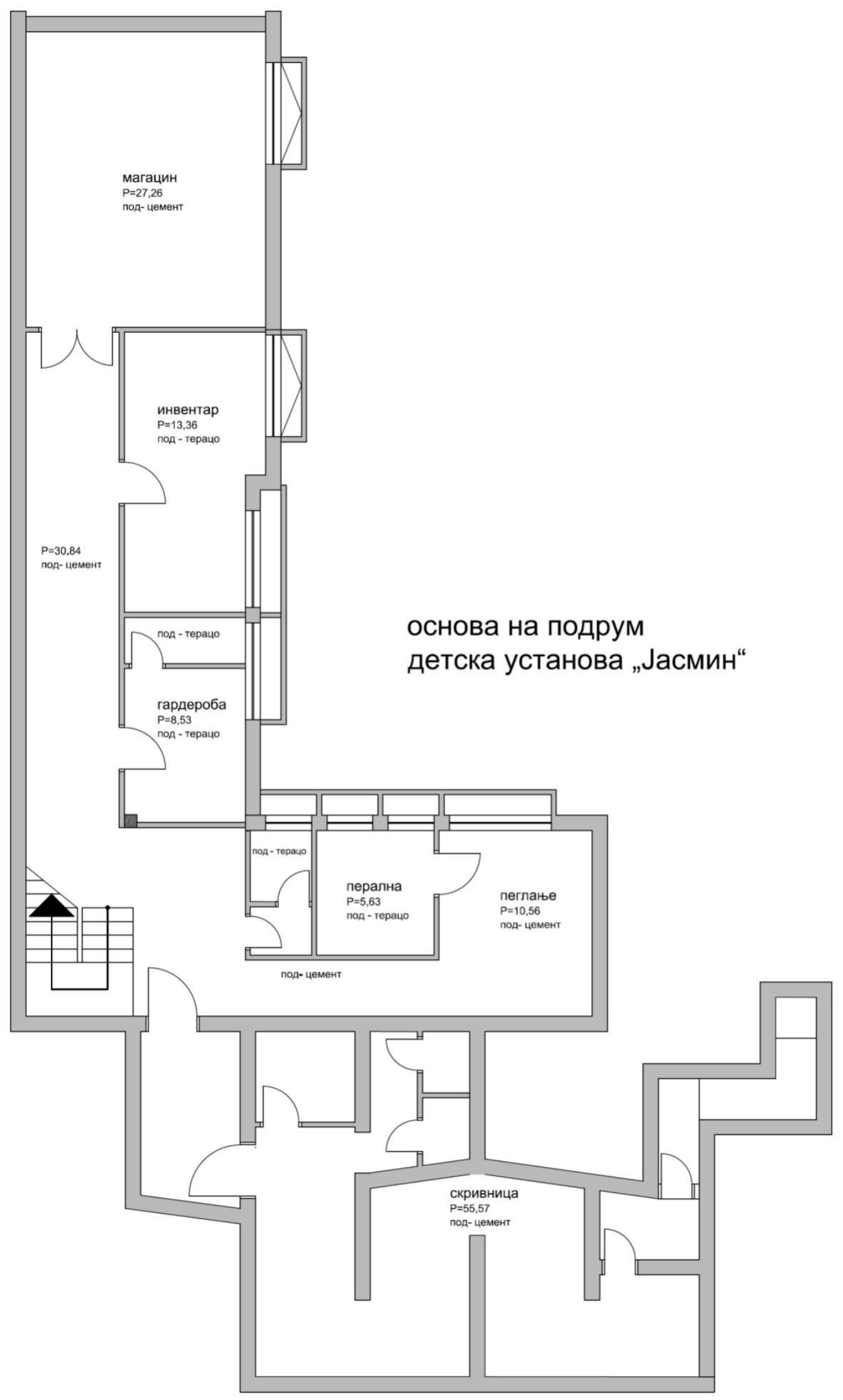




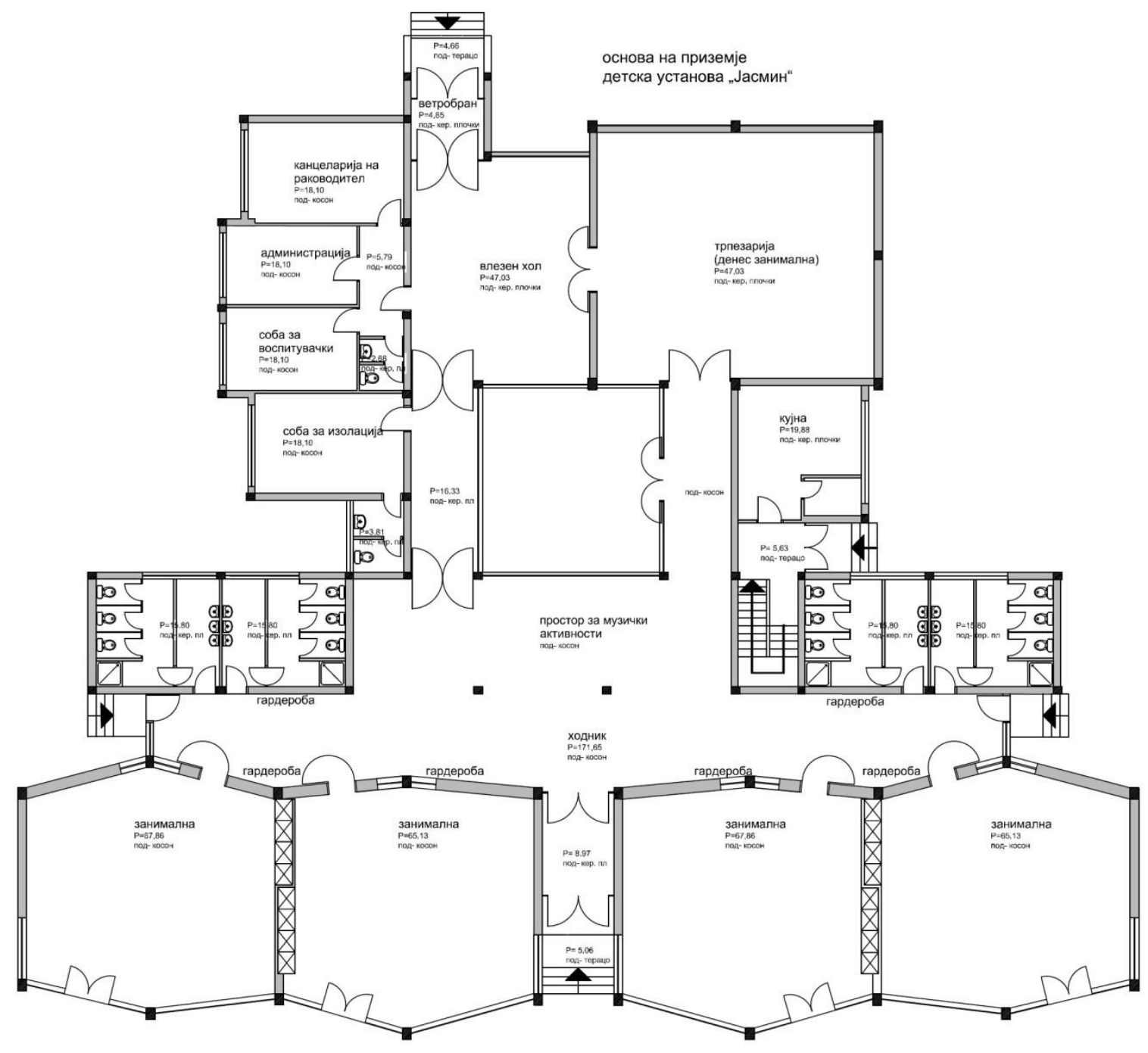




\subsubsection{4. Комбинирана детска установа „Парк“}

Предучилишниот објект „Парк“ е сместен во непосредна близина на Градскиот парк, односно до кружниот тек во Дебар маало. Просторот е слободен од сите страни. Објектот е на приземје и кат и има сопствен двор со мали димензии. Во него се сместени две јаслени групи и шест групи на детски градинки. Капацитетот на објектот е 140 деца од кои 20 во јасли и 120 во градинка. Во објектот се влегува од северната страна, преку посебен влез за јаслите, кои се наоѓаат на катот и влез за во групите од детската градинка. Влезовите во детската градинка се со ветробран и има доволно простор да се остават детските колички. Преку него се влегува во просторијата за повеќе намени со големина од $103.02 \mathrm{~m}^{2}$. Од левата страна на повеќенаменската сала е сместена просторијата за наставничките, канцеларијата на раководителот на детската установа, амбулантата, собата за хигиеничарките и санитарниот јазол за вработените. На спротивната страна од влезот, односно во задниот дел на повеќенаменската сала се сместени просториите за престој на децата: две занимални со големина од $55,50 \mathrm{~m}^{2}$, централизирани гардероби и два санитарни јазла. Од десната страна на влезот започнува ходник во кој од десната страна е лоцирана дистрибутивната кујна, а од левата страна две занимални исти како претходно опишаните, со иста големина и иста поставеност на гардеробата и санитарните простории.

Преку посебен влез се влегува на вториот кат кој има ветробан и претпростор за оставање на детски колички. Преку вертикална комуникација се стига на катот каде преку тријажата се влегува во ходник. Просторната организација е иста како и на приземјето. Од левата страна на ходникот се наоѓa канцеларијата за воспитувачите, млечната кујна, просторијата за хигеничарките и санитарниот јазол за вработените. Наспроти влезот се наоѓаат две занимални со големина од $38.73 \mathrm{~m}^{2}$ и санитарните јазли. Од десната стрна на ходникот се поставени останатите две занимални со иста просторна зафатнина и позиција на санитарните јазли. Гардеробата за разлика од приземјето е разредена. Сите занимални се сместени на јужната страна. Подовите се од паркет со соодветна звучна и термичка изолација, како и изолација од влага. Подот во санитарните простории е од керамички плочки. Вратите од занималните поради евакуација се отвараат на надвор, како и сите влезни врати. Прозорците се со големина од 335/223 см, со парапет од 55 см. Долниот дел од прозорците се отвараат само со вентус, за да не може децата да ги отвараат, а да имаат поглед кон дворот што одговара на нивната висина.

Во подрумот е сместена пералната која претставува централна перална и пеглара, која ги опслужува сите објекти кои спаѓаат под надлежност на матичниот објект $13^{- \text {-т }}$ Ноември. 
Компаративна анализа на предучилишните установи во општина Центар со современите тенденции во проектирањето и артикулирање на одредени интервенции во просторот како одговор на психо-физичките потреби на децата

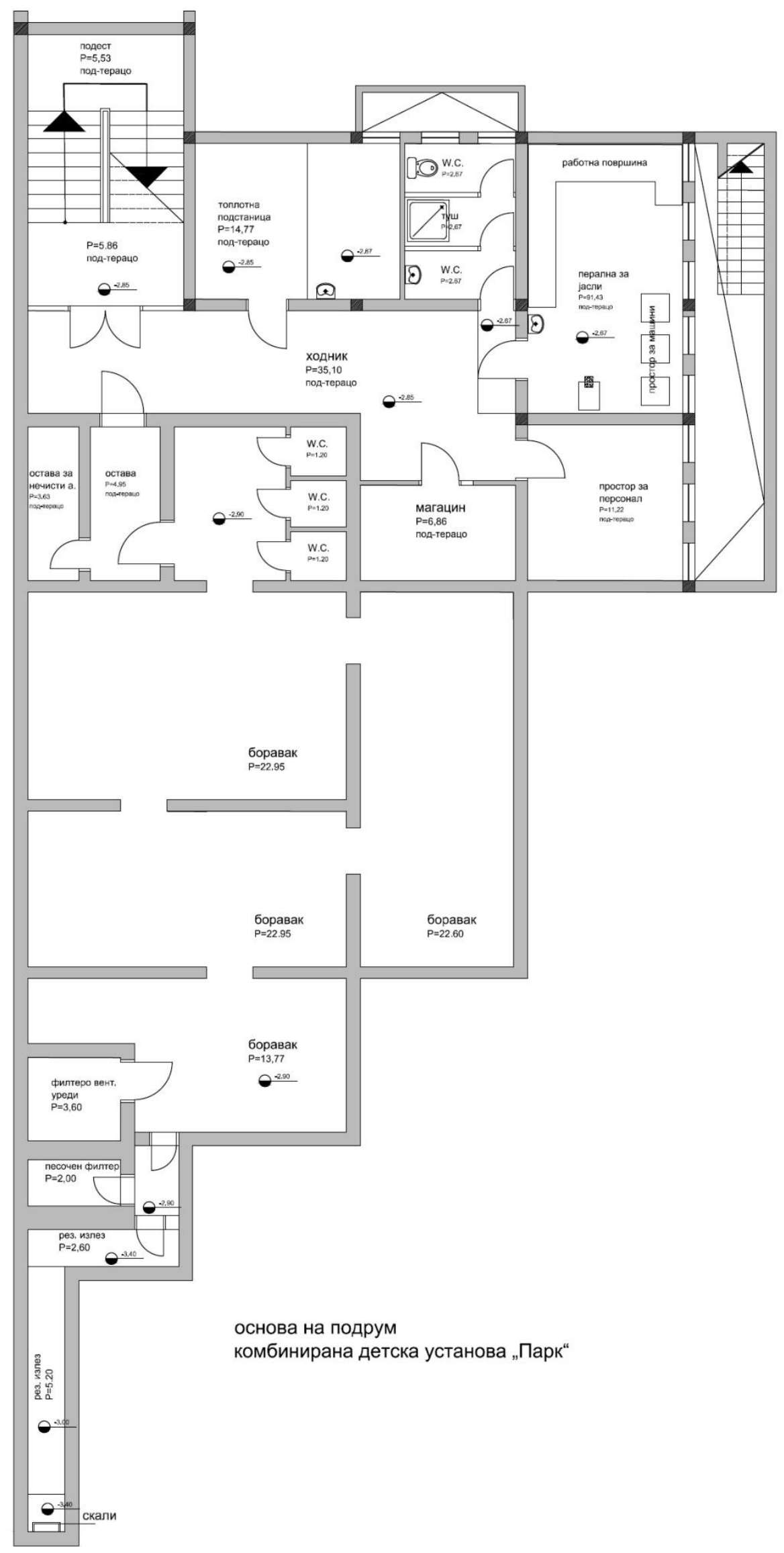




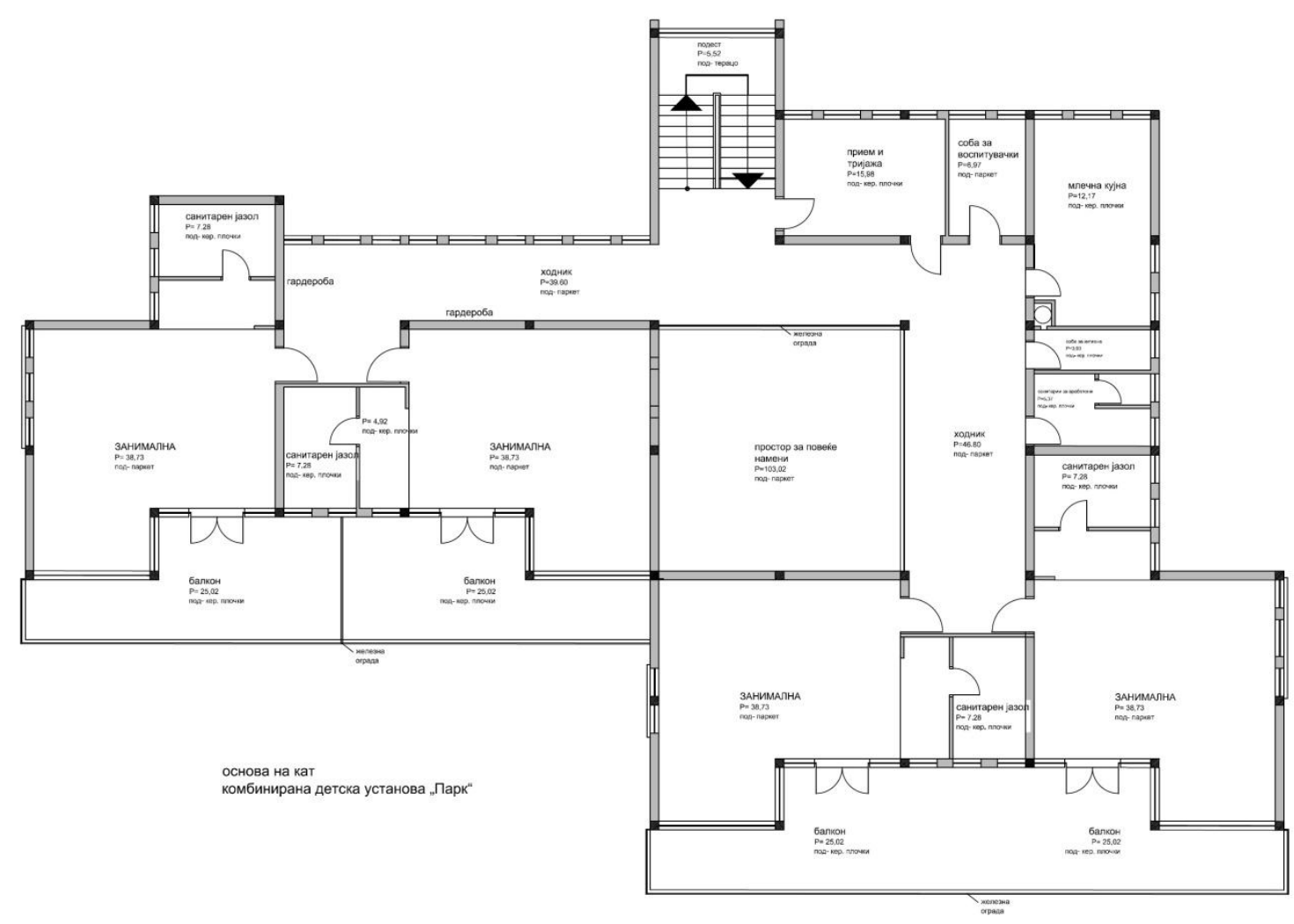


Компаративна анализа на предучилишните установи во општина Центар со современите тенденции во проектирањето и артикулирање на одредени интервенции во просторот како одговор на психо-сризичките потреби на децата 
6.1.2. Предучилишни објекти кои влегуваат во состав на групацијата на установи „Кочо Рацин“

\subsubsection{1. Предучилишна установа „Кочо Рацин“}

Матичниот објект „Кочо Рацин“ е сместен во Капиштец, на локација која е доста густо населена. Објектот претставува градба од монтажен тип, кој е изграден по скопскиот земјотрес, во 1964 година. Во осумдесеттите години е извршена доградба, каде е сместена централната кујна и просториите за остава. Проектираниот капацитет на објектот е 150 деца. Објектот поседува

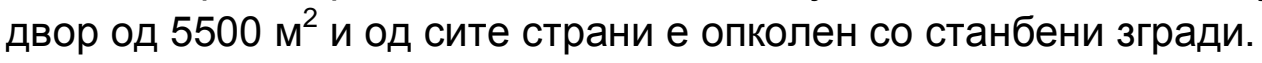

Предучилишната установа „Кочо Рацин“ е приземен објект, составен од три бараки поврзани со два влезни хола и доградбата. Во објектот се влегува преку два влеза кои се сместени на северо-источната страна. Преку првиот влез, условно кажано прв, се влегува во влезниот хол, кој претставува чекална за родителите. Од десната страна на влезниот хол се влегува во барака каде се сместени четири занимални со димензии од $20.12 \mathrm{~m}^{2}, 31.84 \mathrm{~m}^{2}, 37.63 \mathrm{~m}^{2}$ и $43.07 \mathrm{~m}^{2}$, две санитарни простории и пералната. Занималните се свртени кон југо - исток и југо - запад. Гардеробата е поставена по должината на ходникот. Од левата страна на влезниот хол се влегува во друга барака, каде се сместени две занимални, кои по потреба, поради хармониката која се наоѓa меѓу нив можат да се спојат. Во една од занималните, со големина од $38.73 \mathrm{~m}^{2}$, е издвоен дел, кој претставува музичко катче, што го користат сите групи во зависност од распоредот на неделните активности. Занималните се свртени кон северо-источната страна. Во оваа барака е сместен и санитарнот јазол за децата и возрасните, како и административните простории за техничкиот персонал, наставничките, сметководството и директорот.

Во третата барака се сместени четири занимални, со димензии од 29.44 $\mathrm{M}^{2}, 27.86 \mathrm{~m}^{2}, 25.08 \mathrm{~m}^{2}$ и $29.62 \mathrm{~m}^{2}$, психологот и двете санитарни простории за децата. Гардеробата е разредена.

Во задниот дел од објектот е сместена централната кујна, оставата, просторијата за дидактика и топлотната станица. 
Компаративна анализа на предучилишните установи во општина Центар со современите тенденции во проектирањето и артикулирање на одредени интервенции во просторот како одговор на психо-сризичките потреби на децата 


\subsubsection{2. Предучилишна установа „Бели Мугри“}

Објектот е лоциран во месноста „Багремар“ на улица „Ацо Караманов“. Пуштен е во употреба во 1981 година. Објектот е од тврда градба, со големина од $1200 \mathrm{~m}^{2}$ и двор од $2333 \mathrm{~m}^{2}$. Целиот објект ја прати конфигурацијата на теренот, има форма на многуаголник и се состои од ниско и високо приземје.

Ниското приземје е на ниво на теренот и ги содржи административните и техничките простории што се во склоп на програмата на објектот. Оттука, во дистрибутивната кујна, пералната, топлотната станица, машинската куќичка и просторијата во која е сместен фрилтро-вентилациониот уред, се влегува преку економскиот влез, кој е свртен на северната страна. Наспроти дистрибутивната кујна се сместени скалите и лифтот кој овозможува пренесување на храната во високото приземје. Преку административниот влез се влегува во просторијата за наставниците, негователките,техничкиот персонал, лекарот и собата каде се чува дидактиката.

Во виското приземје се наоѓa просторот за повеќе намени, кој има кружен облик и седум занимални кои се радијално поставени. Покрај секоја занимална е поставен санитарен јазол и дел за гардеробирање. Ходникот е концентрично поставен и ја дели салата за повеќе намени од занималните. Двете јаслени простории се помали за сметка на млечната кујна и просторијата за остава. Помеѓу двете јаслени групи е сместена тријажата. На катот има три влеза, два за групите за детска градинка и еден за јаслените групи. 
Компаративна анализа на предучилишните установи во општина Центар со современите тенденции во проектирањето и артикулирање на одредени интервенции во просторот како одговор на психо-сризичките потреби на децата 
Компаративна анализа на предучилишните установи во општина Центар со современите тенденции во проектирањето и артикулирање на одредени интервенции во просторот како одговор на психо-сризичките потреби на децата 


\subsubsection{3. Предучилишна установа „Панорама“"}

Предучилишната установа „Панорама“ е сместена на падините на Водно. Располога со корисна површина од $1130 \mathrm{~m}^{2}$ и дворно земјиште од $2066 \mathrm{~m}^{2}$, на две нивоа. Објектот е изграден во 1985 година и претставува градба од постојан карактер. Проектираниот капацитет изнесува 140 деца, поделен во четири единици на детска градинка и четири единици на јаслени групи. Објектот е денивелиран, со што се вклопува во теренот. Има два влеза за единиците на детската градинка и јаслите, како и административен и економски влез, со што е обезбедено независно одвивање на процесите во објектот. Бидејќn објектот ја следи линијата на теренот проектиран е така да две единици од градинката се на висинска кота +90 см, а повеќенаменската сала, дистрибутивната кујна и административните простории на висинска кота $\pm 0,0$ см, додека останатите две единици од градинката на висинска кота $+180 \mathrm{~cm}$. Занималните се ориентирани кон исток и зафраќаат површина од 54,75 м². Секоја занимална има посебен санитарен јазол како и зона за гардеробирање.

На еден дел од објектот се појавува и кат, каде се сместени четири јаслени групи, тријажата, пералната, млечната кујна и просторијата за наставничките. Ориентацијата и просторната организација на јаслените занимални е иста како на приземјето, со таа разлика што зафаќаат површина од $40,0 \mathrm{~m}^{2}$. Од секоја занимална се излегува на тераса. 
Компаративна анализа на предучилишните установи во општина Центар со современите тенденции во проектирањето и артикулирање на одредени интервенции во просторот како одговор на психо-сризичките потреби на децата 
Компаративна анализа на предучилишните установи во општина Центар со современите тенденции во проектирањето и артикулирање на одредени интервенции во просторот како одговор на психо-сризичките потреби на децата 
Компаративна анализа на предучилишните установи во општина Центар со современите тенденции во проектирањето и артикулирање на одредени интервенции во просторот како одговор на психо-сризичките потреби на децата 


\subsubsection{4. Прдучилишна установа „Наум Наумовски-Борче“}

Објектот е сместен во близина на Универзалната сала. Зафаќа големина од $1706 \mathrm{~m}^{2}$ и двор од $948 \mathrm{~m}^{2}$. Изграден е во 1960 година и првенствено функционирал како библиотека. Бидејќи објектот се наоѓал веднаш до фрабриката „Треска“, се наметнала потребата за изградба на институција која ќе ги згрижува децата на вработените, па била пренаменета во предучилишен објект. Во почетокот на седумдесеттите години е извршена доградба. Објектот е приземен, со подрумски простории.

Во стариот дел се влегува од западната страна. Тука се наоѓаат четири занимални за јаслените групи со две санитарни простории, три занимални за детска градинка како и тријажата, просторија за воспитувачите и лекарот. Занималните се со различна големина, од најмалата која зафаќа површина од $26.25 \mathrm{~m}^{2}$, до најголемата од $40.99 \mathrm{~m}^{2}$. Занималните имаат ориентација кон исток и запад. Гардеробата е од разреден карактер. Стариот дел е поврзан со новиот преку тесен ходник.

Во новиот дел се влегува од јужната страна. Во него се сместени четири занимални со големина од $39.0 \mathrm{~m}^{2}$, две од $44.55 \mathrm{~m}^{2}$ и една од $48.89 \mathrm{~m}^{2}$. Има две санитарни простории, кои опслужуваат по две занимални. Гардеробата е концентрирана, односно по една просторија за две занимални. Во новиот дел е сместена оставата, просторијата за дидактика, канцеларијата на директорот и санитрниот јазол за вработените. Просторијата која го поврзува новиот со стариот дел е искористена како музички кабинет. Во подрумот е сместена дистрибутивната кујна, пералната и пегларницата. 
Компаративна анализа на предучилишните установи во општина Центар со современите тенденции во проектирањето и артикулирање на одредени интервенции во просторот како одговор на психо-сризичките потреби на децата 


\subsection{3. Предучилишни објекти кои влегуваат во состав на групацијата на} установи „Раде Јовчевски-Корчагин“

\subsubsection{1. Предучилишна установа „Раде Јовчевски-Корчагин“}

„Раде Јовчевски-Корчагин“ или „Пинокио“ претставува објект, кој уште од почетокот на пуштање во фрнкција, намената му била да врши предучилишна дејност. Пуштен е во употреба во 1972 година. Тоа е објект од тврда градба со приземје, кат и дворно место. Сместен е во склоп на Градски зид на булеварот „Кочо Рацин“ и од сите четири страни е опколен со згради. Проектираниот капацитет на објектот изнесува 200 деца.

Влезот во објектот е од југо-западната страна. Преку ветробран се влегува во влезниот хол, каде од десната страна е сместена салата за повеќе намени со димензии од $100 \mathrm{~m}^{2}$, а од левата страна се сместени административните простории, односно канцеларијата на директорот и секретарот. Со навлегување во објектот, одејќи кон централниот дел, се поминува од чајната кујна, која е поврзана со централната кујна, сместена во подрумот и просторијата за повеќе намени, во која се одвиваат различни активности, како учење на странски јазици, изучување на компјутерски вештини и друго. Во централниот дел на објектот е сместена гардеробата која е од концентриран карактер. Во овој дел се сместени четири занимални за групите

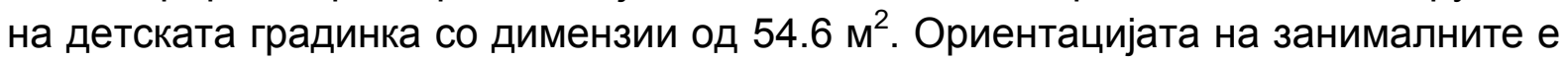
кон северо - исток. Секоја занимална има свој санитарен јазол.

На катот се сместени седум занимални од кои три јаслени групи и четири групи градинки. Две од јаслените единици се сместени во занимални со димензии од $23.1 \mathrm{~m}^{2}$ и $19.1 \mathrm{~m}^{2}$. Овие занимални дополнително се доградувани поради големиот број на деца кои ја посетуваат детската установа. Третата јаслена група и останатите групи на градинка се сместени во занимални со димензии од $55.2 \mathrm{~m}^{2}, 44.9 \mathrm{~m}^{2}$ и $60.6 \mathrm{~m}^{2}$. Секоја од овие занимални има свој санитарен јазол и излез на терасата. Гардеробата е концентрирана и е сместена веднаш до скалишните краци, каде родителите ги оставаат своите деца. На катот е сместен лекарот, просторијата за наставничките, просторија за администрацијата, млечната кујна и санитарните јазли за вработените.

Во подрумскиот дел е сместена централната кујна, магационот за чување на храната, централната перална и пегларница, како и просториите за техничкиот персонал. 
Компаративна анализа на предучилишните установи во општина Центар со современите тенденции во проектирањето и артикулирање на одредени интервенции во просторот како одговор на психо-сризичките потреби на децата 
Компаративна анализа на предучилишните установи во општина Центар со современите тенденции во проектирањето и артикулирање на одредени интервенции во просторот како одговор на психо-сризичките потреби на децата 
Компаративна анализа на предучилишните установи во општина Центар со современите тенденции во проектирањето и артикулирање на одредени интервенции во просторот како одговор на психо-сризичките потреби на децата 


\subsubsection{2. Комбинирана детска установа „Пепелашка“}

Комбинираната детска установа „Пепелашка“ е сместена во објект кој претставува индивидуален објект за домување. Но со национализирање и одземање од еврејската заедница е пренаменета во објект за вршење на предучилишна дејност. Објектот е составен од подрум, приземје, кат и веранда. Има сопствен двор со мали димензии и во истиот е сместена салата за повеќе намени, која не е поврзана со предучилишниот објект.

Во подрумот е сместена дистрибутивната кујна, магацинот, просториите за перење и пеглање. На приземјето се наоѓ централната гардероба и осум занимални со мали димензии од $16.8 \mathrm{~m}^{2}, 21.8 \mathrm{~m}^{2}$ и $25.6 \mathrm{~m}^{2}$. Лево и десно од централната гардероба се влегува во занималните, четири од едната страна и четири од другата страна. Групацијата од четири занимални преставува една група на детска градинка. Поради малите димензии во секоја просторија се врши посебна активност, во една се спие, во друга се јаде во трета се игра. Покрај занималнате сместен е и санитарен јазол за деца и возрасни.

Катот просторно е исто организиран како и приземјето, со таа разлика што на местото во приземјето каде се наоѓа гардеробата, на катот се сместени две простории за администрацијата.

\subsubsection{3. Детска градинка „Палешка“}

Детската градинка „Палешка“ е сместена на кеј „13 Ноември“ во станбената зграда број два, на втори кат. Претставува станбена единица пренаменета во детска градинка и како таква во целост не може да ги исполни стандардите и нормативите за вршење на дејноста.

Во неа се наоѓаат две занимални со големина од $39.80 \mathrm{~m}^{2}$ и $47.87 \mathrm{~m}^{2}$. Има еден санитарен јазол за двете занимални, и концентрирана гардероба. Тука се сместени дистрибутивната кујна, која е со многу мали димензии како и просторијата за наставничките и негувателките. 
Компаративна анализа на предучилишните установи во општина Центар со современите тенденции во проектирањето и артикулирање на одредени интервенции во просторот како одговор на психо-сризичките потреби на децата 
Компаративна анализа на предучилишните установи во општина Центар со современите тенденции во проектирањето и артикулирање на одредени интервенции во просторот како одговор на психо-сризичките потреби на децата 
Компаративна анализа на предучилишните установи во општина Центар со современите тенденции во проектирањето и артикулирање на одредени интервенции во просторот како одговор на психо-сризичките потреби на децата 
Компаративна анализа на предучилишните установи во општина Центар со современите тенденции во проектирањето и артикулирање на одредени интервенции во просторот како одговор на психо-сризичките потреби на децата 


\section{2. Анализа на предучилишните установи}

Предучилишните установи во општина Центар можат да се поделат :

Во поглед на градбата:

- Објекти со привремен карактер, како градинката „Кочо Рацин“ и

- Објекти од цврста градба - сите останати 10 предучилишни објекти.

Во поглед на намената:

- Објекти кои уште при проектирањето намената им е одвивање на предучилишна дејност; „13 Ноември“, „Јасмин“, „Парк“, „Панорама“, „Бели Мугри“, „Раде Јовчевски-Корчагин“ и

- Објекти пренаменети во предучилишни установи; „Н.Н. Борче“ библиотека, „Кукушка“ - индивидуални објект за домување, „Палешка“ станбена единица и „Пепелашка“ - индивидуални објект за домување.

Според спратноста :

- Објекти кои се развиваат само на приземје; „Н.Н. Борче“, „Јасмин“,

- Објекти кои се развиват само на приземје без подрумски простории, „Кочо Рацин“ и „Кукушка“,

- Објекти на приземје и кат; „Панорама“, „Бели Мугри“, „13 Ноември“, „Парк“ и „Р.J. Корчагин,

- Објект на приземје и два ката; „Пепелашка“,

- „Палешка“ кој е сместен во објект за колективно домување.

Според големината на дворното место :

- Дворови кои ги исполнуваат стандардите според големината по глава на дете по метар квадратен; „Кочо Рацин“, „Панорама“, „Бели Мугри“ и „13 Ноември“,

- Објекти кои имаат дворна површина со мали димензии, кои не го исполнуваат стандардот; „Парк“, „Р.Ј. Корчагин“ и „Пепелашка“, „Н.Н. Борче“" и „Јасмин“,

- Предучилишни објекти кои немаат дворно земјиште; „Кукушка“ и „Палешка“.

Според големината на занималните:

- Објекти кои ги задоволуваат стандардите за големина на занималната како, „Панорама“, „Бели Мугри“ и „13 Ноември“„,Парк“ и „Јасмин“,

- Објекти во кои одреден број од занималните ги задоволуваат условите, а дел не, „Р.Ј. Корчагин“- од единаесет, девет ги исполнуваат стандардите, а две не ги исполнуваат. Во овие две знимални се сместени јаслените 
единици. Ист случај е и со објектот „Н.Н. Борче“, во кој од дванаесет занимални само три го исполнуваат стандардот.

- Објекти во кои занималните не го исполнуваат стандардот за големина, „Кукушка“ „Палешка“ и „Кочо Рацин“,

- Објектот „Пепелашка“ во однос на просторната организација на занималните е поспецифичен, поради тоа што во четири занимални со мала големина престојува една група на градинка. Според тоа, во првата се спие, во втората се јаде, во трета се извршуваат фризички активности, а во четвртата умствени активности. Според некои странски автори овој модел на одделување на различни функции во посебни простории претставува најдобар начин за правилен развој на децата.

Организацијата на просториите во кои престојуваат децата, како занималните, санитарните јазли и делот за гардероборање во одделни објекти е различно структирирана:

- Во објектите „Панорама“, „Бели Мугри“, „13 Ноември“, „Парк“ и „Р.J. Корчагин“, секоја занимална има посебен санитарен јазол и место за гардеробирање,

- Објектите „Кукушка“, „Палешка“ и „Н.Н. Борче“, се организирани така да, на две занимални има по еднен санитарен јазлол и една просторија за гардеробирање.

- Во „Кочо Рацин“ на 4 занимални има по еден санитарен јазол, а гардеробирањето е децентрализирано односно шкафчињата се поставени долж ходникот.

- Во предучилишниот објект „Јасмин“ една од занималните нема сопствен санитарен јазол и дел за гардеробирање. Оваа занимална не ги исполнува условите поради нејзината пренамена од трпезарија во занимална. Пренамената е изведена заради намалениот просторен капацитет во објектот. Останатите четири занимални имаат сопствен санитарен јазол и простор за гардероборање.

- Објектот „Пинокио“ во поглед на гардеробирањето е поразличен од останатите објекти, поради централната гардероба која е поставена на приземјето, а притоа ја користат сите занимални.

Занималните според ориентацијата можат да се поделат на:

- Занимални со поволна ориентација, како во објектите „Парк“ орентирани кон југ, „Јасмин“ кон југо- запад,

- Објекти со добра ориентација, „13 Ноември“ - стариот дел кон исток новиот дел кон југ, „Панорама“ кон исток и „Кукушка“ кон исток.

- Објекти каде занималните се свртени кон сите четири страни, „Кочо Рацин“, „Н.Н. Борче“, „Бели Мугри“, „Р.Ј. Корчагин“ и „Пепелашка“. 
- Објект кој нема поволна положба, „Палешка“ орентиран е кон север.

Во поглед на навлегувањето на светлината во занималните :

- Занимални кои имаат странични прозорци, ориентирани само кон една страна: „Кочо Рацин“ и „Кукушка“,

- Занимални каде има прозорци ориентирани кон две страни: Р.J. Корчагин“, „Парк“, „Јасмин“, „Пинокио“ и „Палешка“,

- Во објектите „Бели Мугри“ и „Панорама“ покрај страничните прозори осветлувањето е дополнето и со високи прозорци.

- Во предучилишната установа „13 Ноември“ занималните во стариот дел имаат прозорци ориентирани само кон една страна, додека во новиот дел прозорците се ориентирани кон две страни. Истото се случува и во објектот „Н.Н. Борче“.

Според функциите кои се одвиваат во занималните, поделени се на:

- Мултифункционални занимални, кои се поделени во различни зони каде се спие, јаде или врши психо-фризичка активност. Тоа се објектите „13 Ноември“, „Јасмин“, „Кукушка“, „Кочо Рацин“, „Бели Мугри“, „Н.Н. Борче“ ,Р.J. Корчагин“, и „Палешка“,

- Во објектот „Панорама“ поради малиот број на деца кои ја посетуваат установата, а големиот простор кој го поседува објектот, една занимална се користи само за спиење, а друга за јадење и одвивање на фризички и психички активности,

- Во „Пепелашка“ поради многу малите димензии на занималните, истите се групирани во четири и прават една целина. Во првата се јаде, во втората се спие, во третата се одвиваат умствени активности, а во четвртата фризички.

Предучилишните објекти во поглед на заедничките простории може да се поделат:

- Објекти кои имаат сала за повеќе намени, „13 Ноември“, „Парк“, „Панорама“, „Бели Мугри“ и „Раде Јовчевски- Корчагин“

- Објектот „Пепелашка“ има сала за повеќе намени, со таа разлика што се наоѓa надвор од објектот и не е поврзана со него. Поради тоа во зимскиот период не се користи.

- Објектот „Јасмин“ има импровизиран простор кој се користи како повеќе наменска сала, а најмногу како простор по музичко изразување. Во минатото тој се користел како простор за гардеробирање и

- Објекти кои немаат сала за повеќе намени, „Кукушка“, „Кочо Рацин“, „Н.Н. Борче“ и „Палешка“, 
Во поглед на тоа дали објектите имаат просторија за изолација, поделени се на:

- Објекти кои имаат соба за изолација, „13 Ноември“, „Јасмин“, „Парк“, „Раде Јовчевски Корчагин“, „Кочо Рацин“, „Н.Н. Борче“, „Панорама“, „Бели Мугри“,

- Објекти кои немаат соба за изолација, „Кукушка“, „Пепелашка“, „Палешка“.

Во поглед на постоење на просторија за креативно изразување:

- Објекти кои имаат просторија за креативно изразување, „13 Ноември“, „Јасмин“, „Раде Јовчевски- Корчагин“ и „Н.Н. Борче“,

- Објекти кои немаат просторија за креативно изразување „Парк“, „Кочо Рацин“, „Бели Мугри“, „Панорама“, „Кукушка“, „Пепелашка“, „Палешка“.

Во сите предучилишни објекти на територијата на општина Центар се задоволени стандардите од аспект на економско-техничките простории. Во трите матични објекти има централна кујна, додека во нивните клонови има дистрибутивна кујна. Во делот каде се сместени јаслените групи односно на катот, доколку објектот е на кат, имаат и млечни кујни. Во сите објекти има перална и пегларница, освен во „Кукушка“ и „Палешка“, кои претставуваат станбени единици пренаменети во предучилишен објект. Тие ги користат пералните од некој од објектите во кој припаѓаат.

Девет објекти се затоплуваат со централното градско греење, додека „Панорама“ и „Пепелашка“ имаат сопствен систем на греење.

Според горе наведените аналази, разгледувајќи ги поединечно предучилишните објекти може да се констатираат следните забелешки:

Предучилишниот објект „Кочо Рацин“ не задоволува ниту еден стандард пропишан со Правилникот за стандардите и нормативите за вршење на дејноста на детски граднинки. Тој е објект од привремен карактер, составен од три бараки од англиски тип „Лукс“. Во него се сместени десет занимални со мали димензии, од кои девет не го задоволуваат стандардот од минимум $40 \mathrm{~m}^{2}$. Од секоја занимална нема директен пристап кон дворот, а ориентацијата на дел од занималните е свртена кон неповолна положба. Еден санитарен јазол опслужува четири занимални. Во објектот нема сала за повеќе намени, освен еден мал простор во кој е сместено катчето за музичка култура, а истиот е сместен во една од занималните. Овој концепт на просторно организирање на кабинетот по музичка култура е погрешен, бидејќи не претставува посебена просторија, туку е сместен во една од занималните. Затоа при нејзино користење од страна на една од групите на детската градинка, треба да се влезе во занималната, а притоа да се наруши работата на децата кои веќе 
престојуваат во неа. Димензиите на централната кујна не соодветсвува на големината, која треба да обезбеди број на оброци по глава на дете.

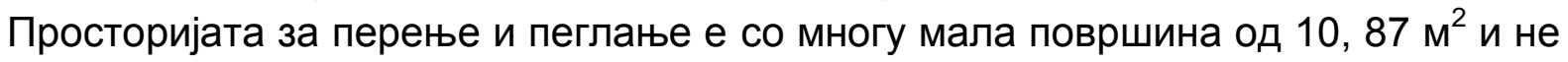
соодветсвува на бројот на децата кои престојуваат во објектот.

Предучилишната установа „Н.Н. Борче“ е објект кој првично не бил наменет за вршење на предучилишна дејност. Тој е составен од два дела, таканаречени стар и нов дел. Половина од занималните го задоволуваат нормативот за големина, а половина не. Од занималните нема директен излез кон дворот, а дел од занималните се свртени кон неповолна ориентација. Еден санитарен јазол опслужува две занимални, гардеробирањето во стариот дел е разредено, а во новиот дел концентрирано. Нема сала за повеќе намени, а како таква ја користат просторијата за музичка култура. Тоа е просторија која претходно била занимална, но поради поврзувањето на двата дела од објектот, истата покрај кабинет за музичко претставува и комуникациски дел. Во стариот дел поврзувањето е направено преку тесен ходник, кој заземал површина од една од занималните, со што истата ги намалила димензиите.

Предучилишните објекти „Бели Мугри“ и „Панорама“ ги задоволуваат нормите и параметрите за вршење на предучилишна дејност. Занималните се со големина која го задоволува стандардот, ориентацијата е поволна, секоја занимална има сопствен санитарен јазол, простор за гардеробирање и директен пристап кон дворот. Санитарниот јазол има визуелен контакт од занималната и гардеробата со што се овозможува целосна прегледност на децата од страна на негователите и наставниците. Во објектот „Панорама“ на катот е сместена јаслената група и детската градинка за деца од 2 до 3 години. Санитарниот јазол е во склоп на занималната со што се овозможува преповивање и одржување на хигиената на децата, без притоа да се користат други простории наменети за таа цел. Од секоја занимална има пристап кон тераса. Останатите простории се така организационо поставени, со што се добива една целина за непречено извршување на сите функции кои треба да произлегуваат од објектите.

Објектот „Раде Јовчевски-Корчагин“ претставува градба чија намена од самиот почеток на изградба е наменета за вршење на предучилишна дејност и како таква ги задоволува во целост нормите и стандардите. На приземјето се

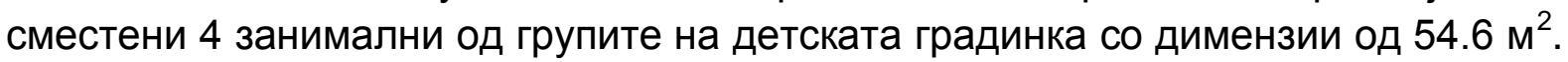
Ориентацијата на занималните е неповална. Секоја занимална има свој санитарен јазол, кој има визуелна комуникација однадвор. Гардеробирањето е концентрирано и е сместено пред занималните во централниот дел на објектот во голем хол. На катот се сместени 3 јаслени групи и 3 групи на детски градинки. Двете јаслени групи се сместени во релативно мали занимални, кои не го задоволуваат стандардот. Немаат посебен дел каде се врши 
преповивање на децата и санитарен јазол, но од друга страна се орентирани кон поволна положба. Останатите занимални го задоволуваат стандарод за големина на просторијата каде престојуваат децата. Санитарните јазли се во склоп на занималната и имаат визуелна прегледност однадвор. Тријажна просторија не постои. Еден вид на импровизирана тријажа е сместена во склоп на гардеробата која е од концентриран тип. Во поглед на заедничките простории објектот има сала за повеќе намени со релативно голем капацитет и просторија за повеќе намени, во која се одвиваат активности, како комјутерски вештини, изучување на странски јазици и слично.

Предучилишната установа „Пепелашка, претставува индивидуален објект за домување, пренаменет во предучилишен објект и како таков ги задоволува нормативите колку што овозможува просторната организација во истиот. Занималните се со многу мали димензии, па затоа се групирани и формираат една целина, односно занимална поделена во посебни зони. Поделеноста во преградени зони претставува најдобар начин на организираност на занималните, но од друга страна немаат визуелн контакт. Сето ова ја усложнува работата на наставниците и негователите поради неможноста да имаат соодветен видик над децата. Друг сегмент што го усложнува беспрекорното функционирање на објектот е тоа што вертикалната комуникација е сместена пред секоја занимална. Салата за повеќе намени се наоѓа надвор од објектот и не е поврзана со истиот, со што во зимските месеци не се користи. Во објектот се сместени 1 јаслена група и 7 групи на детски градинки, од кои 2 групи од детските градинки се организирани да престојуваат во втората смена.

Предучилишната установа „Палешка“ е сместена во станбена единица. Во неа се сместени две занимални кои престојуваат хетерогени групи, односно помешани се деца од различни години, тоа претставува неповолен фрактор за развој на децата. Бидејки установата е лоцирана на кеј „13 Ноември“, бучавата е присутна за време на целиот престој на децата. Од друга страна пак бучавата на децата која настанува при нивните активности е неповолна за околните станови кај е сместена самата установа. Занималните се со задоволителна големина, а слободните активности мора да ги изведуваат на терасата, бидејќи немаат простор за повеќе намени. Занималните се ориентирани кон северната страна, што преставува неповолна положба.

Предучилишниот матичен објект „13 Ноември“ во голем дел ги исполнува стандардите за вршење на предучилишна дејност. Во него се сместени десет групи на детски градинки и две јаслени групи. На приземјето има осум занимални од кои пет се со голем капацитет од $72.4 \mathrm{~m}^{2}$, ориентирани се поволно. Останатите се со големина од $54.33 \mathrm{~m}^{2}$. На катот се сместени две јаслени групи и две групи на детски градинки на возраст од 2 до 3 години. Во 
склоп на јаслените групи се сместени санитарните јазли и делот за преповивање на бебињата. Во занималните од приземјето има директен излез кон дворот, а на катот излез кон тераси. Има сала за повеќе намени со голем капацитет, кабинет по музичко и ликовно изразување, со што се опфатени сите сегменти за правилен развој на детето. Недостаток на објектотот е тоа што нема перална, па алиштата се носат во централната перална во објектот „Парк“.

Во објектот „Јасмин“ делумно се задоволени нормативите за вршење на предучилишна дејност од аспек на просторната организација. Недостаток преставува една од занималните, која е пренаменета од трпезарија, каде во нејзина близина нема санитарен јазол и простор за гардеробирање. Нема простор за повеќе намени, а дворот исто така е со мали димензии, за да се задоволат одредени физички активности. Делот кој порано претставувал концентрирана гардероба е пренаменет во дел за музички активности. За таа цел гардероборањето сега е сместено долж ходниците кои ги поврзуваат занималните со останатите простории. Четирите занимални ја задоволуваат големината и за секоја има посебен санитарен јазол.

Објектот „Парк“ ги задоволува сите организациони параметри. Недостаток преставува малото дворно земјиште. Поради недостаток на простории училната во која се изучуваат странски јазици е сместена во ветробранскиот простор.

Предучилишната установа „Кукушка“ претставува индивидуален објект за домување, пренаменет во детска градинка. Како пренаменет објект има свои недостатоци. Има многу мала дворна површина и нема сала за повеќе намени. Има 2 занимални со хетерогени групи. 


\section{7. АНТРОПОМЕТРИСКА АНАЛИЗА НА ПРЕДУЧИЛИШНИТЕ ДЕЦА, ДОБИЕНА ПРИ ИСТРАЖУВАЊЕ НА ПРЕДУЧОЛИШНИТЕ УСТАНОВИ}

За да се овозможи правилен раст и развој на предучилишните деца, покрај прилагодувањето на средината во која престојуваат, неопходна е употреба и на ергономичен мебел, кој ќ ја следи анатомијата и големината на човековото тело, со што се постигнува комфор при неговото користење.

Тоа подразбира дека при проектирањето на мебел за предучилишните деца нужен е многу внимателен пристап, имајќ во предвид два аспекта. Првиот аспект е анатомијата на детето. Во најраните години од детството 'рбетниот столб, како и сите останати коски, не се доволно оформени, па оттука правилното користење на мебелот е многу важно. Ако елементот за седење е проектиран според потребите на децата, односно ја следи линијата на телото ќе доведува до негов правилен развој. Вториот аспект е големината на елементите од мебелот. Преголемите или премалите парчиња мебел, исто така доведуваат до неправилен развој на телото.

Оттука, анализата на антропометријата на децата е многу битна, бидејќи во овој период тие растат многу брзо и со секоја наредна година мерките на телото се менуваат.

Во овој труд се направени антропометриски анализи во една од предучилишните установи во општина Центар - „13 Ноември“, со цел да се добијат релевантни податоци за мерките на децата од предучилишниот период, со кој ќе се овозможи правилно проектирање на мебелот и споредба со постоечкиот мебел во другите предучилишни установи.

Извршени се мерење на 80 деца, во четири различни групи, во кои влегуваат по 20 деца од секоја група. Првата група ја сочинуваат деца од првата мала група од 2 до 3 годиша возраст, во втората група влегуваат деца од втората мала група од 3 до 4 години, во третата влегуваат деца од средната група од 4 до 5 години и во четвртата влегува големата група од 5 до 6 години.

Антропометриската анализа поединечно по групи е прикажана во следните табели: 


\section{І-ва мала група 2-3 години}

Висина 96

Висина на око

86
Висина на max. дофат
115,5

Должина задник колено

29

Висина на коленица

30,5

Висина на потколеница 25

Должина задник потколеница

28

Висина на рамена во седечка положба

Ширина на рамена

29

Ширина од лакт до лакт 38

Ширина на колкови

25

Висина на потпирање на лакт

\section{7,5}

Табела 8 


\section{II-ра мала група 3-4 години}

\begin{tabular}{ll}
\hline Висина & 108
\end{tabular}

Висина на око 96

Висина на тело во
седечка положба

Висина на max. дофат 129

Должина задник -
колено

Висина на коленица 32,5

Висина на потколеница 26, 5

Должина задник - 34

потколеница

Висина на рамена во
седечка положба

Ширина на рамена 30

Ширина од лакт до лакт 38

Ширина на колкови 26

Висина на потпирање
на лакт

Табела 9 


\section{Средна група 4-5 години}

\begin{tabular}{lc}
\hline Висина & 110 \\
\hline Висина на око & 100 \\
$\begin{array}{l}\text { Висина на тело во } \\
\text { седечка положба }\end{array}$ & 60 \\
\hline
\end{tabular}

Висина на max. дофат

131

Должина задник -
колено

Висина на коленица 33,5

Висина на потколеница 28, 5

Должина задник - $\quad 38$

потколеница

Висина на рамена во

седечка положба

37

Ширина на рамена 30

Ширина од лакт до
лакт

Ширина на колкови 27

Висина на потпирање на лакт

Табела 10 


\section{Голема група 5-6 години}

\begin{tabular}{lc}
\hline Висина & 125 \\
\hline Висина на око & 112 \\
$\begin{array}{l}\text { Висина на тело во } \\
\text { седечка положба }\end{array}$ & 66 \\
\hline
\end{tabular}

Висина на max. дофат 148

Должина задник -
колено

Висина на коленица 37

Висина на потколеница 33

Должина задник - 39

потколеница

Висина на рамена во
седечка положба

Ширина на рамена 31

Ширина од лакт до
лакт

Ширина на колкови 30

Висина на потпирање 23
на лакт

Табела 11 
При снимањето на предучилишните објекти во општина Центар, извршени се мерења и на мебелот кој го користат децата. Постојат два вида на столови со различни динемзии. Едниот тип на столови е со помали димензии со висина на седлото од 28 см, должина на предната страна на седлото од 36,5 см, а должината на задната страна е 29 см и ширина на седлото од 30 см. Вториот тип на столови се со поголеми димензии. Висината на седлото е $35 \mathrm{~cm}$, должината е 30,5 см а ширината е 30 см.
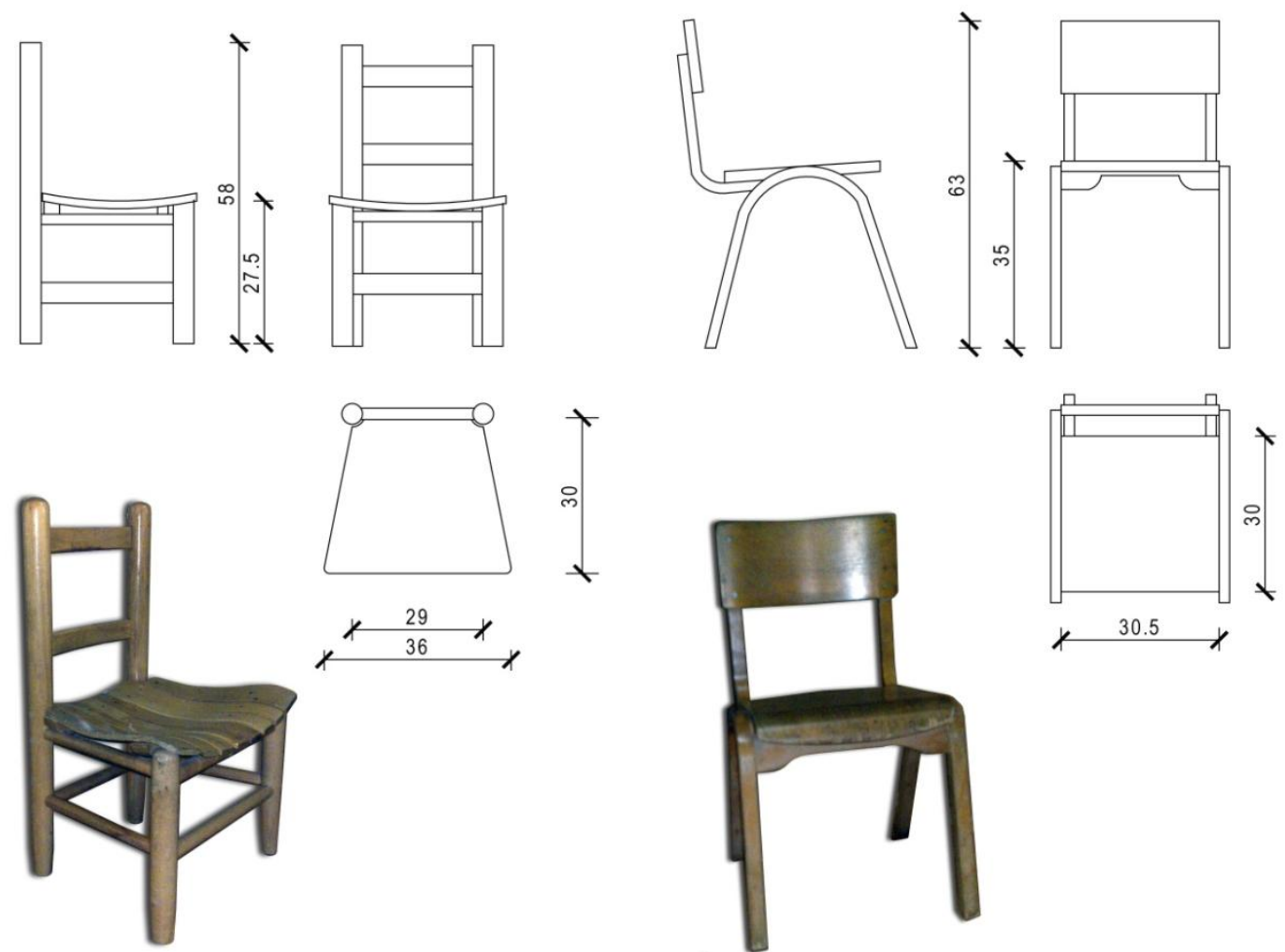

СЛИКА 15

Димензии на столици

За правилно седење, димензиите на седлото треба да одговара со димензиите на човековото тело. Притоа, висината на седлото не би требало да е поголема од висината на подколеницата. Тоа овозможува нозете слободно да го допираат подот и се избегнува притисокот кој настанува во подколеницата. Исто така ширината на седлото не смее да е поголема од должината на задникот до подколениците. Ширината на седлото треба секогаш да е помала од мерката - должина на задникот до подколеницата. Со ова не доаѓa до напрегнување на мускулите на бутот и до трпнење на лумбалниот дел. Должината на седлото треба целосно да ги опфати димензиите на задникот, односно да не излегува од димензијата пропишана за седлото. 
Од анализата на антропометриските податоци добиени од мерењето на децата, може да се констатира дека децата од првата мала група можат да ги користат малите столчиња, но тие во целост не се вклопуваат со мерките на децата. Средната големина на висината на подколеницата на децата на возраст од 2 до 3 години изнесува 25 см, а висината на седлото е со висина од 27,5 см, што доведува до висење на ноџињата. Ова не претставува голем недостаток, бидејки тие со врвот од стапалото сепак можат да го допираат подот. Ова важи за сите деца, на кои должината на подколеницата им е помала од 27,5 см. Должината на седлото од 36,5 см на предниот дел и 29 см на задниот дел од седлото, ги задоволуваат мерките на ширината на колковите која изнесува 25 см. Ширината на седлото која изнесува 30 см не се вклопува со димензијата на должината на задникот до подколеницата која е 28 см. Според мерките добиени од мерењата на децата, идеална димензија на седлото на столот би била со ширина од 27 см, висина од 24 см, додека должината треба да остане иста.

Децата од втората мала група, исто така можат да ги користат столчињата со помалата димензија, бидејќи висината на подколеницата е 26,5 см, должината на задникот до подколеницата изнесува 34 см, а ширината на колковите 26 см. Овој тип на стол најмногу одговара за оваа возрасна група.

Децата од средната група, на возраст од 4 до 5 години би требало да ги користат помалите столчиња. Висината на столот е 27,5 см, што одговара со висината на подколеницата која изнесува 28,5 см. Должината на седлото е 36,5 см, а ширината на колковите 27 см. Ширината на седлото е $30 \mathrm{~cm}$, а должината на задникот до подколеницата е 38 см. Овој тип на стол одговара на димензиите на децата за оваа возрасна група.

Столот со поголеми димензии ги исполнува условите за користење од големата група деца. Висината на седлото е со висина од 35 см, додека висината на подколеницата е 33 см. Оваа мерка за одреден тип на деца не ги исполнува условите за висина на седлото, но може да се прифати како димензија која одговара. Должината и ширината на седлото 30,5 x 30 см соодветствува на должината на задникот до подколеницата 39,5 см и со ширина на колкови $30 \mathrm{~cm}$.

Од горе наведените анализи може да се заклучи дека постоечките столови во предучилишните установи во општина Центар, со мали измени во целост ќе соодветствуваат со димензиите на децата. Првата мала група може да ги користи столчињата со помали димензии, но доколку се промени висината и ширината на седлото тогаш би се добила димензија која во целост би одговарала на возраста на децата. Втората мала група и средната група можат да ги користат помалите столчиња, без да се изврши некоја битна промена во димензиите, додека големата група може да ги користи столовите 
со поголеми димензии, но под услов да се изврши промена во висината на седлото.

Масите се од ист тип во секоја група. Димензиите кои се употребуваат во сите установи во општина Центар се со висина од 56,5 см и ширина и должина на плотната од 79 см х 79 см. Според Мате Бајлон во книгата „Школске зграде ${ }^{31 “, ~ в и с и н а т а ~ н а ~ п л о т н и т е ~ н а ~ м а с и т е ~ т р е б а ~ д а ~ б и д е ~ н а ~ в и с и н а т а ~ н а ~ л а к т о т ~}$ кој слободно виси во седечка положба. Оттука за правилно димензионирање на масите ќе се користи мерката висина на потпирање на лактот. Оваа висина ќе се добие кога на висината на потколеници ќе се додаде висината на потпирање на лактот.

Првата мала група има висина на подколеница од 25 см и кога ке се додаде висината на потпирање на лактот од 17,5 см се добива димензија од 42,5 см. Оттука, висината на масата треба да изнесува 43 см. Втората мала група има висина на подколеница од 26,5 см и со додавање на висина на потпирање на лактот од 18,5 см се добива висината на масата од 45 см. За децата од средната група висината на масата треба да изнесува 48 см, поради тоа што висината на подколеницата е 28,5 см а висината на потпирање на лактот е 19 см. Висината на масата на децата од големата група треба да биде 56 см, што одговара на постоечката висина на масите во објектите.

Врз основа на добиените анализи може да се констатира дека висината на масите треба да се проектира според наведените мерки, при што за секоја група да има различна димензија. За поедноставување при производството, висината за првата и втората мала група да биде со димензија од 45 см. Таа висина за малата група ќе биде нешто повисока, но тоа не претставува проблем бидејќи се работи за разлика само од два сантиметра. Висината на масите за секоја група може да се решава со принципот на поставување на механизам за усогласување на висината.

Ширината и должината на масите покрај тоа што треба да соодветствуваат на мерките на децата треба да бидат прилагодени и на активностите кои тие ги извршуваат во текот на денот. Оттука, разбирлива е оваа големина на плотната, бидејќи на неа се јаде, се извршуваат слободни активности, но и активности поврзани со наставниот процес.

\footnotetext{
${ }^{31}$ Bayen, Mate. Shkolske zgrade. Beograd, 1962. Str. 159.
} 


\section{8. АРТИКУЛИРАЊЕ НА ОДРЕДЕНИ ИНТЕРВЕНЦИИ ВО ПРОСТОРОТ (ЗАНИМАЛНИТЕ) КАКО ОДГОВОР НА ПСИХО-ФИЗИЧКИТЕ ПОТРЕБИ НА ДЕЦАТА}

Правилниот развој на предучилишните деца е могу важен фрактор во процесот на изградба на личноста. Настаните и искуствата од најраното детство силно влијаат во формирањето на карактерот на личноста. Во најраните години од детството се случуваат најмногу промени, повеќе отколку во било кој друг период од животот. Физички телото најмногу расте и се развива, промени настануваат во социјалната интеракција, во говорот, во помнењето, резонирањето, како и во сите останати човекови функции. Во таа насока и фризичкиот простор во кој престојуваат децата најголем дел од денот, во предучилишните установи, треба да биде функционално и правилно организиран за да се постигне правилен психо- физички развој.

Претходната анализа на предучилишните установи во општина Центар, укажува на тоа дека во некои од нив може да се артикулираат одредени интервенции, се со цел да се постигне атмосфрера која ќе пружи правилен развој .

\section{1. Артикулирање на одредени интервенции во занималните}

Занималните како централно место во кое се одвииваат сите функции во текот на престојот на децата, подлежат на најголемо артикулирање на просторот. Според ова, предмет на анализа ќе бидат активностите кои ги извршуваат децата, како предуслов за соодветно опремување и уредување на занималните.

Активностите на децата можат да бидат поделени на:

- Спиење,

- Јадење,

- Играње,

- Воспитно- образовна активност

\subsection{1. Спиење}

Спиењето претставува активност која е присутна во сите возрасни групи на предучилишните деца. Креветите кои се користат во одредени занимални се статични, додека во други се склопувачко - расклопувачки, сместени во ормари. Во јаслените групи, каде доенчињата поминуваат најголем дел од времето во спиење, креветите се статични. Во занималните каде престојуваат деца од 2 до 3 години креветите можат да бидат статични, но и не мора. Ова зависи од големината на занималната. Доколку занималната има помали 
димензии креветите треба да се од склопувачко расклопувачки карактер, за да се овозможи повеќе простор за другите активности кога децата не спијат.

Просторот за спиење или креветите можат да бидат позиционирани во одреден дел од простор кој ќе биде или делумно преграден или ќе биде поставена хармоника. Пример на ваков простор за спиење има во предучилишната установа „Кочо Рацин“.

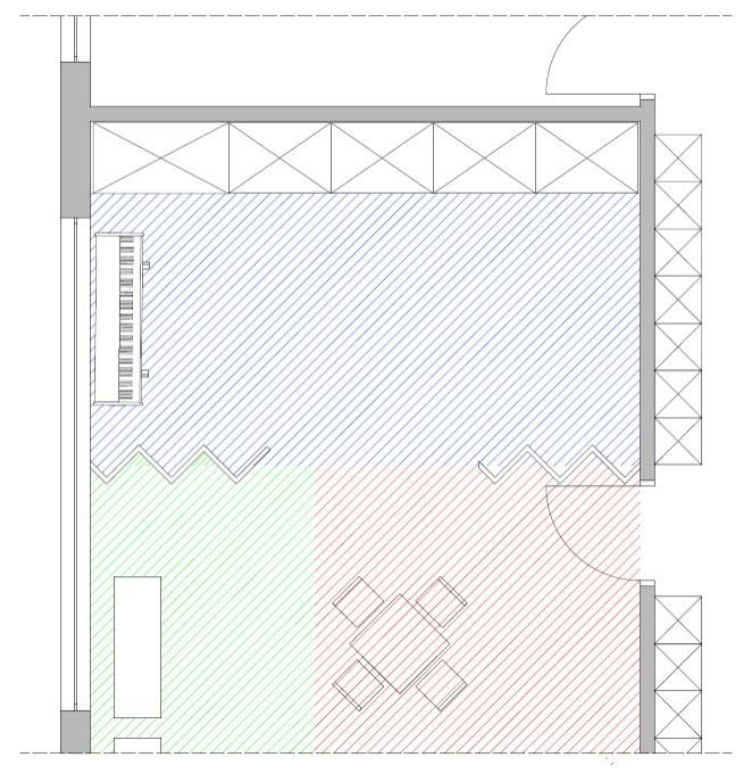

СЛИКА 11

Занаимална од предучилишниот објект „Кочо Рацин“

Просторот за спиење може да биде одделен од занималната, поставен во сосема друга просторија.
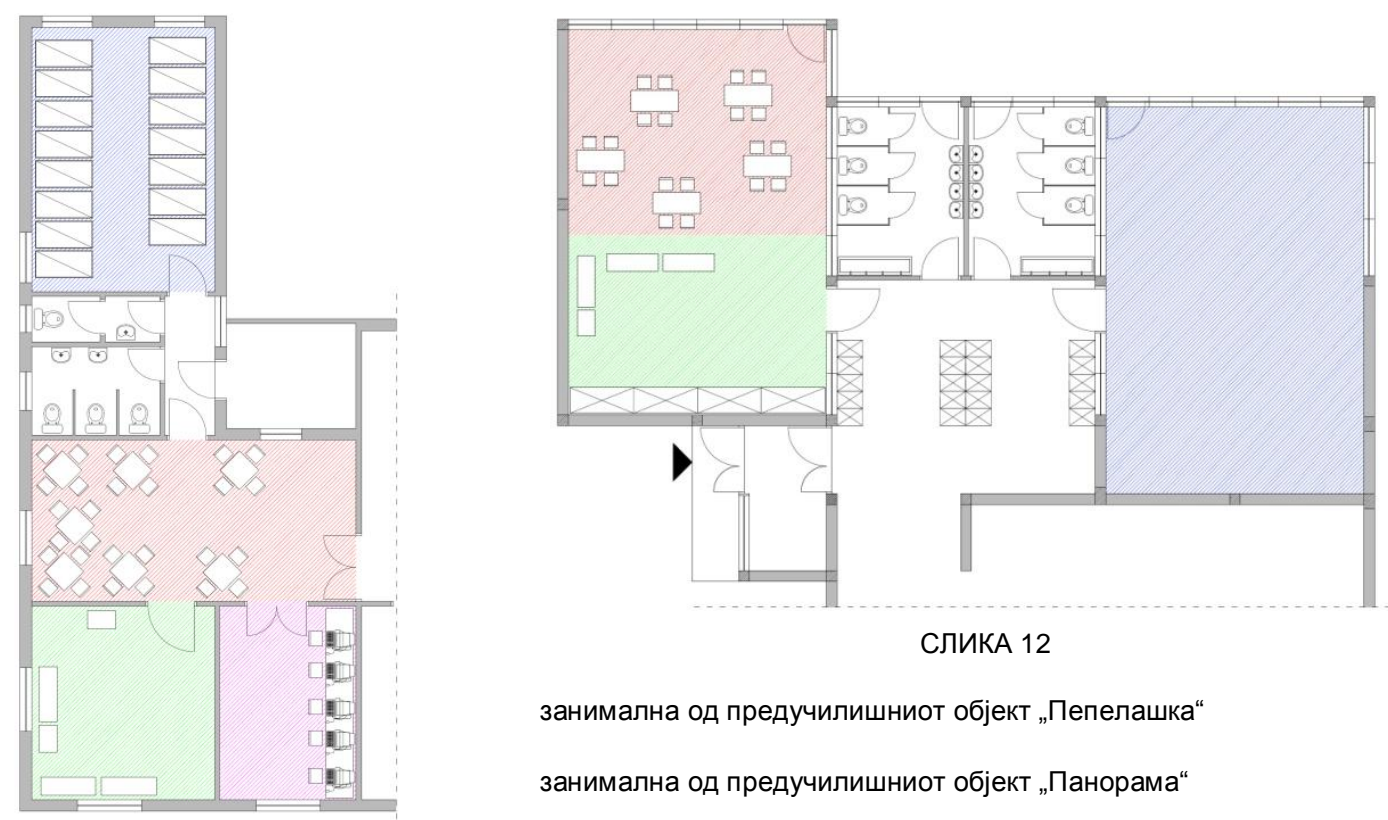

СЛИКА 12

занимална од предучилишниот објект „Пепелашка“

занимална од предучилишниот објект „Панорама“ 
Според Даница Б. Станкович и други автори кои се занимаваат со проектирање на предучилишни установи, зоната каде спијат децата, најдобро е да биде во одвоена просторија или преградена со ниши. Во овој случај секое дете си го знае својот кревет. Се одвојува целосно функцијата спиење од другите активноси, а децата можат да се одмораат или спијат и кога не е време за спиење, определено според програмите на самите установи. Статичните кревети имаат подобри карактеристики бидејќи душеците не мора постојано да бидат склопувани и расклопувани, со што подолго време ја задржуваат својата форма и намената за која служат. Во градинките во општина Центар, одделувањето на просторот за спиење како посебен не е можен, бидејки занималните треба да имаат поголеми димензии од пропишаните. Единствена ваква интервенција може да се постигне во предучилишниот објект „13 Ноември“, каде димензиите на еден дел од занималните изнесува $72.40 \mathrm{~m}^{2}$. Во овој случај, бројот на децата се намалува поради големата зафатнина на делот за спиење.

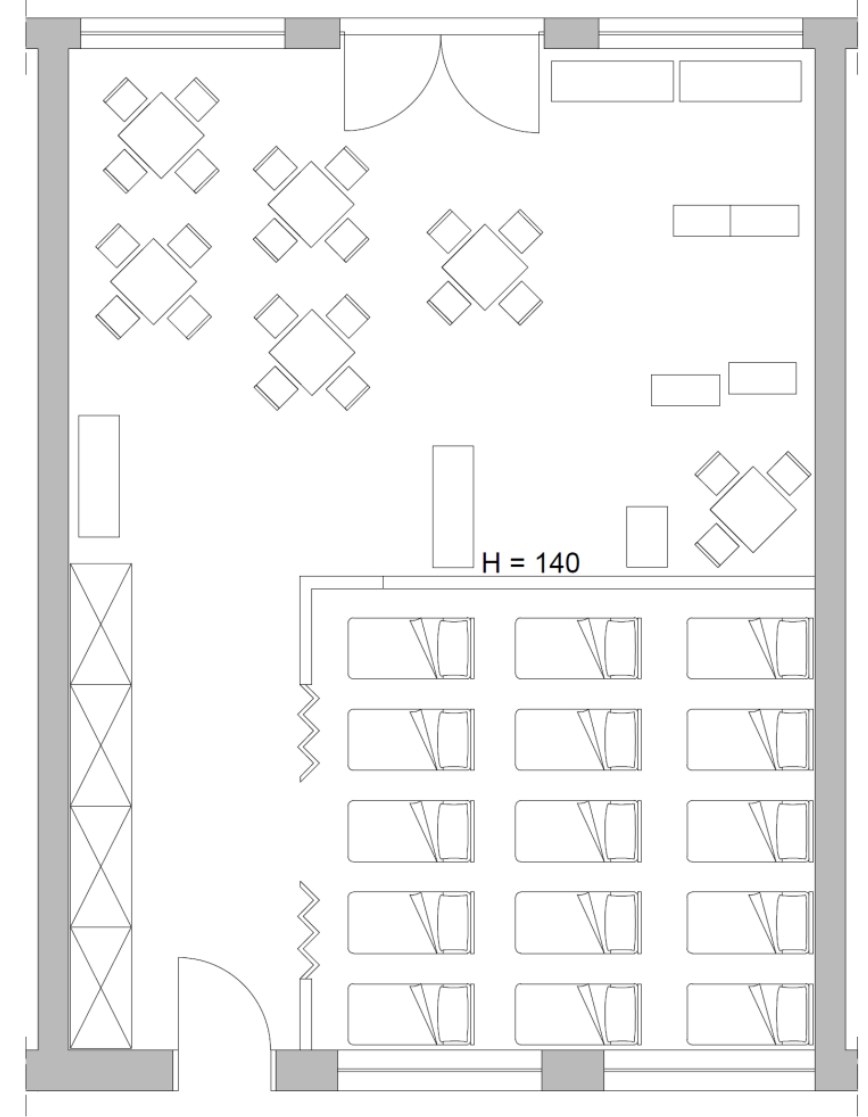

СЛИКА 13

Артикулација на конкретна занимална

\subsubsection{Jadeњe}

Бидејќn децата половина од своето време го минуваат во предучилишните објекти, јадењето се јавува повеќе пати во денот, во различни облици. Кај јаслените групи јадењето не е одвоено во посебен дел од 
просторот, туку тоа се одвива низ целата површина на занималната, која негователките во даден момент ја сметаат како најповолна. Кај доенчињата јадењето се извршува со помош на возрасни лица, бидејќи тие не се способни сами за тоа, па оттука не постои определен дел од занималната наменет за оваа активност. Во детските градинки, децата со нивното созревање, во извршувањето на оваа функција се се посамостојни. Тие стекнуваат навика и одговорност при извршувањето на оваа активност. Па така, во занималната треба да се овозможи посебен простор за тоа. Најчесто, јадењето се одвива на масите и столчињата кои го зафаќаат централниот дел од занималната, истите оние кои, кога не се јаде се користат во процесот на играње или извршување на некоја воспитно-образовна активност. Занималните кои се во состав на предучилишните објекти во општина Центар се конципирани на овој начин од причини што вака опремениот простор бара помал капацитет.

Јадењето може да се обавува или во посебен дел во занималната, наменет само за тоа, или во сосема различна просториија - трпезарија. Првиот начин на организирање на просторот бара голема површина на занималната. Вториот, според Даница Б. Стошич, подразбира дополнување на основата на установата со додатна просторија. Тоа може да има негативно влијание на децата, поради губењето на домашната атмосфера на која се навикнати, бидејќи тие подобро се чувствуваат во ист, единствен простор во кој ги извршуваат сите активности. Во ваков концепт и негувателките не можат да обрнат вистинско вниманите врз децата.

Според ова најдобар концепт на организирање на јадењето е во посебен простор во самата занимална, со што се одвојува процесот јадење од останатите функции, а се постигнува и поголема хигиена.

\subsection{3. Играње}

Најголем дел од времето децата поминуваат во играње. Преку играта тие постигнуваат социјална интеракција, доживуваат нови искуства, а поголемите предшколски деца почнуваат да ги контролираат своите емоции при групна работа. За развојот на карактерот многу влијае средината и социјалната интеракција, а тоа се постигнува преку заедничка игра на децата. Проф. Д-р. Мирослава Николоска во нејзиниот труд „Развојна психологија“, го објаснува поимот игра, од аспект на третманот на различни теоретичари. Според едни, играта се смета како средство во кое детето го троши вишокот на енергија која не може да ја потроши на друг начин. Според други, играта преставува надополнување на енергијата на детето, која ја потрошило учејќи непознати и нови задачи. Третата теорија, играта ја гледа како средство за вежбање на вештините кои се основни за преживување. Според овие теории, може да се констатира дека играта претставува главно средство за вкупниот психофизички развој на детето. 
Според многу автори кои се занимаваат со развојна психологија на децата, играта е поделена во повеке форми. Како прва и наједноставна претставува набљудувачката игра, која се појавува во првите години од раѓањето на детето. Детето не е во состојба да воспостави социјална интеракција со друго дете, затоа тоа само ги набљудува другите деца или возрасни во нивните активности. Доенчето многу повеќе игра само или со некоја играчка, која во тој момент му го привлекла вниманитето.

Бидејќи доенчињата од деветтиот до дванесетиот месец, во кој влегува првата јаслена група, поголемиот дел од времето го поминуваат во спиење или лежење, занималните треба да бидат организирани така да има детски креветчиња кои нема да бидат од склопувачко - расклопувачки тип. Доенчињата на оваа возраст почнуваат да го осознаваат светот и моторички подобро да созреваат отколку претходно и тие почнуваат самостојно да се движат во просторот лазејќи. Затоа во занималните треба да се обезбеди доволен простор во кој тие би се движеле. Јаслените занимални во кои се сместени овие групи на деца не бараат големи простории, не помалку од 40

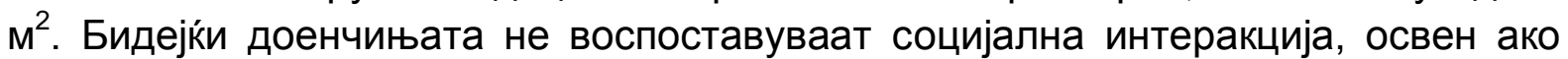
некој возрасен не го овозможи тоа, потребата од посебен простор за играње поделен со ниши не е задолжителен. Од мебелот кој е потребен во занималната треба да има кутии или полици каде би се сместувале играчките.

Први обиди за воспоставување на некоја социјална интеракција детето ги прави преку солитарни игри. Детето од набљудувач, почнува да воспоставува некаква врска со децата кои веќе играат. Можеби постои некоја социјална интеракција но таа е сеуште слаба. ${ }^{32}$ И оваа игра е најприсутна кај доенчињата, односно кај децата на возраст од раѓањето до 3 години.

Доенчињата на возраст од 18 месеци до 2 години, во која спаѓа втората јаслена група, прават напори да се исправат, држејќи се за некој предмет кој ќе се најде пред нив или се во фаза на проодување, но сеуште не се сосема стабилни. Поради ова, во занималните покрај креветчињата треба да има полици, или кутии за чување на играчките кои ќе бидат без остри ивици или од материјал кој нема да може да предизвика повреди при паѓањето на доенчето при воспоставување на рамнотежа, кога се обидува да оди. Бидејќи оваа возраст покажува поголема социјална интеракција, односно во одреден краток период можат да си играат само две деца, занималните треба да бидат нешто поголеми од претходните, бидејќи процесот на игра бара и поголем простор.

Доенчињата од 2 до 3 години, почнуваат самостојно да јадат, да играат игри кои бараат седечка положба како на пример, редење коцки, црткање и

\footnotetext{
${ }^{32}$ Николоска Мирослава, Развојна психологија - детство. Скопје: Народна и универзитетска библиотека „св. Климент Охридски“, 2002. Стр. 235.
} 
слично, па затоа во занималните се поставуваат маси и столчиња проектирани на нивната висина. Бидејќи децата почнуваат да играат меѓу себе, а има и присуство на повеќе мебел, просторијата бара поголем простор, не помалку од $50 \mathrm{~m}^{2}$. На овој тип занимални креветчињата можат, но и немора да бидат од склопувачко - расклопувачки карактер.

За децата од периодот на рано детство, на возраст од 3 до 6 години, карактеристични се паралелните, асоцијативните и кооперативните игри. Парарелната игра е облик на играње на децата едно покрај друго со слична содржина, кои притоа немаат социјална интеракција. Aсоцијативната игра овозможува социјална интеракција на група деца, но нема конкретна поделба на улогите и постигнување на крајна цел. Кооперативните игри претставуваат највисоко ниво на социјална интеракција во предучилишниот период каде децата се групирани за да извршуваат поедини активности во кои се постигнува одредена цел. Децата ги имаат поделено своите обврски.

Децата од малата група, на возраст од 3 до 4 години се групираат во група од две до три деца, но нивната интеракција трае од 20 до 30 минути. Многу често ја менуваат играта и чуствата. Поради тоа занималните треба да бидат поделени во помали простории, преградени со физички прегради или прегради направени од самиот мебел или од играчките. Се препорачува да има повеќе такви мали зони за играње, бидејќи како што е погоре опишано тие сакаат да играат во помали групи и многу често им се здосадува од играта, па од една игра се префрлаат на друга. Покрај малите преградени зони во занималните треба да има маси и столчиња. Креветчињата се од склопувачко - расклопувачки тип, па кога времето не се користи за одмор или спиење тие се сместени во ормарите во занималните, каде просторот целосно е отворен за слободни или воспитно-образовни активности.

Децата од 4 до 5 години или средната група, се групираат во поголеми групи од три до пет деца. Самостојно ги обавуваат своите активности. На оваа возраст се воспоставуваат и одредени наставни активности. Поради тоа занималната може да биде со помал број на прегради, а поголемиот дел да се отстапи на просторот каде се поставени масите и столовите. На оваа возраст децата покрај слободните игри кои сами ги одбираат, на масите и столовите започнуваат да извршуваат и некои психички активности како цртање, моделирање, решавање на некои задачи.

Децата од 5 до 6 години имаат добра социјална интеракција, се подготвуваат за училишниот период, па затоа поголем дел од просторот го зафраќаат масите и столовите, каде се извршува одредена наставна активност преку игра, како учење на букви, бројќи странски јазик и друго. Прегради треба да постојат, но многу помалку. Поради повисокиот психолошки развој, 
подобрата соработка во група и можноста да го контролираат своето однесување, потребно е во занималните да има помалку преградени делови.

Според горе кажанато може да се заклучи дека во занималните кои одредени делови се преградени, децата се однесуваат подобро. Бидејќи кај предучилишните деца социјалната интеракција е послаба, преградените делови во просторот делуваат позитивно од причини што тие можат да се групираат во помали групи. Интеракцијата меѓу нив трае подолго. Подобро се концентрираат и се поусредоточени на активноста која ја изведуваат, стануваат посамостојни, бидејќи немаат потреба да ги повикуваат воспитувачите при настанување на некој застој на активностите. Не се изложени на постојани погледи и прекинувања од останатите деца или воспитувачите. Детето ако почувствува потреба да остане само, може да се сокрие и повторно да се врати на активностите. Според многу автори кои се занимаваат со предучилишниот период на децата, како Ирван Алтман и проф. Корач, потребата од повлекување на детето за регулирање на степенот на социјална активност, се постигнува доколку постои одреден простор, каде би се засолнило и би останало во него онолку долго колку што е потребно за да постигне некоја психолошка рамнотежа. Оваа психолошка потреба на децата да се повлечат во одреден дел од занималната не преставува психолошка деструкција, туку едноставно детето бара малку одмор од прекумерната интеракција, да се повлече од некој конфликт или малку да се одмори. По постигнувањето на психолошката рамнотежа, детето повторно се враќа на задачата која ја прекинало или на некоја друга, со што одново ја започнува социјалната интеракција.

Преградените зони во занималната може да бидат целосно преградени како посебни простории за одредена активност или делумно преградени, направени од мебел или играчки. Целосно преградените простории не овозможуваат поглед на преостанатиот дел на просторијата, а во исто време и воспитувачите немаат целосна контрола врз децата. Бидејќи помалите деца имаат потреба да бидат во близина на воспитувачите, поради приврзаноста кон возрасни лица, што особено за оваа возрасна група на деца е карактеристично, не се чувствуваат пријатно да престојуваат во целосно преградени делови. Според психологот Мирослава Николоска поврзаноста кон возрасните лица на децата од 2 до 5 година е многу изразена. Кога не се во домот поврзаноста ја покажуваат кон нивните воспитувачи, па оттаму следи и горе наведениот заклучок. Поради ова интеракцијата во парови е мала. Во делумно преградените делови од занималните децата имаат широк поглед кон опкружувањето, па дури и кога воспитувачите се подалеку од нив не им пречи при нивната инеракција, поради тоа што се во нивниот видокруг. Преградите, поради потребата на децата да бидат поврзани со воспитувачите или наставниците, мора да овозможуваат визуелна достапност од сите делови на 
занималната, а тоа се остварува со користење на транспарентни материјали или одредени делови од просторот кој е предвиден да претставува одделна зона да нема никаква визуелна препрека.

Во занималните каде нема прегради, децата се поагресивни, социјалната интеракција е слаба и тие се насочени кон воспитувачите. Децата немаат можност да се засолнат доколку тоа им е потребно, постојано се изложени на погледи од други деца и прекинувањето во процесот на некоја активност е поголем. За разлика од основите кои имаат прегради, во занималните кои немаат прегради децата не се усредоточени на играта, самите не иницираат одрдена активност, истражувачкиот дух го нема и однесувањето на децата е случајно и не се фокусираат на одредена задача долго време. Според Даница Б.Станкович, автор на трудот „Психолошки аспекти и проектирање на детски предучилишни установи“, занималните од отворен тип одговараат на потребите на доенчињата во фразата кога проодуваат, во воспитен модел кога доминантна улога има воспитувачот или кога треба да се постигне подобро раководење со групата.

Според типот на игри тие можат да се поделат во така наречени „чисти“ игри и „валкани“ игри. Во валкани игри спаѓаат оние каде по завршувањето е потребно децата да се измијат или во текот на играта се употребува вода, како моделирање со тесто, пластелин и слично. Затоа треба одреден дел од занималната да се ограничи каде би се одвивала оваа активност, а во непосредна близина да има мијалници.

Во предучилишните установи во општина Центар во сите занимални кои го исполнуваат условот за минимална големина на занималните, треба да се направат делумни прегради во просторот, прегради од елементи од мебел или од играчки кои имаат поголем габарит, како куќучки и слично. Во занималните кои не го исполнуваат нормативот за големина тешко е да се организира просторот со прегради, како би се постигнал правилен психолошки развој на детето. 


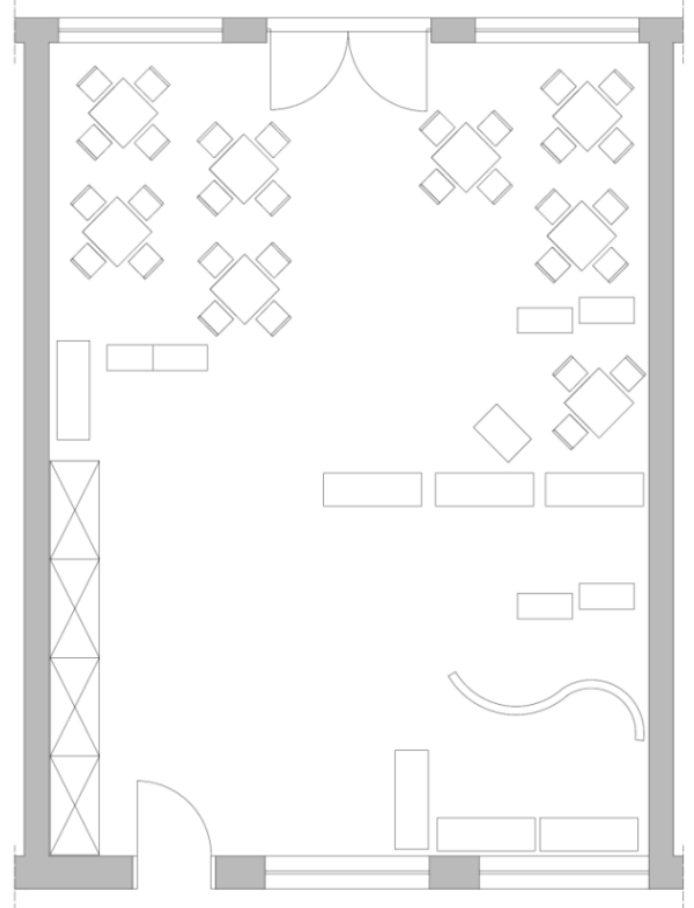

СЛИКА 14

Артикулација на конкретна занимална

\subsection{4. Воспитно-образовни активности}

Во зависност од видот на воспитно-образовните активности се конципира и самиот простор во кој децата престојуваат. Овие активности се карактерисктични за групите на детска градинка, особено на децата од 5 до 6 години. Тие се групирани во централниот дел на занималната и најголемиот дел од времето на овие активности се користи во групна интеракција, насочена кон наставниците, работејќи на маси и столчиња. Според ова, во занималните за средната и големата група треба повеќе простор да се отстапи на делот каде ќе бидат сместени масите и столовите, притоа не занемарувајќи ги деловите каде ќе има прегради, но во помала застапеност од занималните на другите групи. Доколку се работи за некоја физичка активност тогаш се користи истиот простор, каде се сместени масите и столовите, па тие се поместуваат настрана за да се добие целосно празен простор. Поради ова, масите и столовите треба да бидат лесни за манипулација од самите деца, за да може слободно да се движат низ просторот. Лесното маневрирање на овој тип мебел доведува и до одредено групирање на самите деца, доколку од нив тоа го бара некоја активност.

\section{2. Други параметри кои влијаат врз модификацијата на просторот-} занималната

Просторијата во која престојуваат децата треба да биде флексибилна, во смисла на тоа мебелот и преградите кои се наоѓаат во неа, да можат да бидат поместувани од самите деца. Децата комотно се однесуваат во простор 
во кој имаат контрола, односно кога можат слободно да ги движат елементите во него. Со ова децата потполно можат да се вклопат во просторот, да истражуваат, создаваат нови мали простори погодни за нивната активност. Ако просторот е целосно статичен тогаш кај децата настапува несигурност и тие се понесамостојни. Просторот исто така треба да биде јасен, што подразбира дека секој дел од занималната јасно да означува за која функција е наменет. Доколку просторот е хаотичен децата се дезорентирани и секоја активност ја извршуваат со помал капацитет, бидејќи не можат доволно да го воочат просторот. Во овој контекст, може да се каже дека и комуникациските простории во кои се движат децата треба да бидат јасни и прегледни за да не дојде до дезориентација. Ова може да се постигне со вметнување на колорит во самите ходници како на зидовите, така и на подната површина. Исто така просторот треба да е визуелно достапен, бидејќи децата и покрај тоа што во одредено време на денот сакаат да се повлечат во одреден дел или да играат во помали групи, прегледноста на просторот им е многу битна. Од друга страна прегледноста е добра и од безбедносен карактер, бидејќи негователките имаат постојан надзор врз децата. Визуелната достапност освен во занималните треба да биде присутна и во другите простории кои ги користат, како во зоната за гардеробирање, санитарните јазли или комуникациските простории.

Според Мирослава Николоска, битен фрактор за социјална интеракција претставува големината на просториите како и ресурсите кои се наоѓаат во нив. Доколку занималната е премала се зголемува агресивноста и емоционалната возбуда. Во премногу големи простории децата може да се „изгубат“, доколку просторот не е правилно конципиран. Играчките исто така влијаат на интеракцијата на децата, секое дете во одреден период од денот има своја омилена играчка. Спротивно, доколку има помалку играчи, децата се во позиција повеќе да се дружат меѓу себе, односно социјалната интеракција се зголемува.

Многу битен фрактор дали децата ќе го прифатат просторот во кој престојуваат, е дали го сметаат како свое омилено катче. Познато е дека тие релаксирано и позитивно реагираат во познати простори. Оттука занималните треба да бидат функционално проектирани, исто како нивните домови. Да се знае точно каде се јаде, каде се спие, а каде се игра. Просторот треба да биде облепен со нивни цртежи или предмети кои ги направиле во градинката, ${ }^{33}$ со употреба на разновидни, но нежни бои. Ова се прави со цел да може полесно да се прифати просторот. На ваков начин тие се врзуваат за еден простор кој им нуди пријатна, безбедна атмосфера и простор кој нуди целосна „мистерија“, во која можат постојано да истражуваат и во која би сакале повторно да се

${ }^{33}$ Станковић Б., Даница „Психолошки аспекти и проектовање дечјих предшколских установа савремена искуства и тенденције развоја. Докторска досертација. Универзите у Београду, Архитектонски факултет, Београд, 2009. Стр. 150 
вратат. Истражувањето може да се поттикне, на пример, со додавање на куќички во кои децата можат да влегуваат и да се качуваат. Тоа се постигнува и со додавање на разни елементи во просторот, со поставување на мрежи, интересни форми на зидовите на различни нивоа и.т.н. Ваков тип на опрема и елементи во просторот може да се постават во занималната во која престојуваат или во некој посебен простор наменет за вакви активности. Тоа може да биде и просторот за повеќе намени.

Просторот каде престојуваат децата според горе дадените анализи треба да ги содржи сите сегменти, каде детето може да изведува различни активности во одреден дел од денот, односно да биде сложено структуиран. Тоа значи дека тој треба да ги содржи сите функции кои одат во прилог на правилниот психофизички развој на детето.

Од аспект на фризичкиот развој на детето, просторот покрај тоа што треба да задоволува одредена големина, треба да биде и флексибилен. Тоа подразбира дека, доколку се одвиваат некои подинамични физички вежби тие треба да се одржуваат во простор наменет за тоа, како на пример во повеќенаменска сала или на дворна површина. Доколку ваков простор нема, задоволувањето само на психичката компонента не е доволно, бидејќи одвивањето на фризички активности под надзор на обучено лице влијаат позитивно врз правилниот раст и развој на телото. 


\section{9. ДИСКУСИЈА}

При изготвувањето на овој труд користена е во поголем дел странска литература, а во помал домашна литература. Покрај тоа, користени се архитектонски основи на објектите, кои се наоѓаат во Државниот архив на Република Македонија и Архивата на Град Скопје.

Во третата глава дадена е историска генеза на предучилишните установи. Прв облик на предучилишен објект основал германскиот педагог Фредерих Фробел во четириесеттите години на XIX век, чиј пример потоа го следеле и останатите европски земји и Северна Америка. Прв предучилишен објект кој ја имал денешната форма е создаден од Маргарет Мек Милан во 1913 година во Лондон. Оттогаш до денес, градинките го усовршуваат својот изглед како од естетски така и од функционален карактер.

Четвртата глава содржи статистички подадоци за предучилишните установи и предучилишните деца кои ги посетуваат. Во Република Македонија според податоците од Државниот завод за статистика во 2009 година има 22 213 деца кои посетуваат предучилишно образование, од кои половината во Скопје. Во општина Центар, која е предмет на обработка, за разлика од другите општини во Град Скопје, има најмногу деца кои посетуваат предучилишни установи. Ова не само поради фактот дека во оваа општина социјалноекономската состојба на граѓаните е на повисоко ниво од останатите општини, туку и поради околноста дека концентрацијата на вработени во најголем дел од правните субјекти, пред се во државни институции се наоѓа токму во оваа општина. Изразено во бројќи 1657 деца посетуваат 11 предучилишни објекти.

Предучилишните објекти се поделени на јаслени групи и групи на детски градинки. Јаслените групи се поделени на мала јаслена група и голема јаслена група, додека детските градинки во прва и втора мала група, средна група и голема група. Според бројот на деца, во јаслените групи во првата мала група треба да престојуваат од 8 до 10 деца, а во големата од 10 до 12 деца. Во првата мала група треба да има од 12 до 15 деца, во втората мала група од 15 до 18 деца, додека во средната и големата група од 20 до 25 деца. Димензиите на занималните според Правилникот за стандарди и нормативи за вршење на предучилишна дејност на детските градинки, во јаслените простории треба да бидат проектирани со големина од $3,5 \mathrm{~m}^{2}$ по дете. Според ова, занималните за првата јаслена група треба да изнесуваат најмалку $40 \mathrm{~m}^{2}$, а во втората јаслена група од најмалку $45 \mathrm{~m}^{2}$. Занималните во кои се опфатени децата од детските 


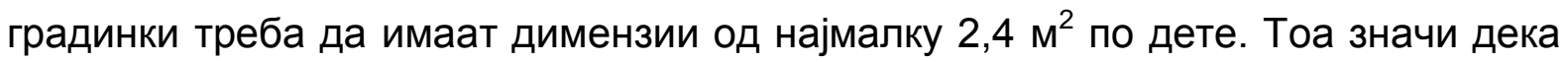
занималните од првата мала група треба да имаат димензии од најмалку $40 \mathrm{~m}^{2}$, занималните од втората мала група димензии од најмалку $45 \mathrm{~m}^{2}$, занималните од средната и големата група од најмалку $60 \mathrm{~m}^{2}$.

Доколку се спореди бројот на децата во предучилишните установи во општина Центар со големината на занималните во поглед на прашањето дали го исполнуваат стандардот, може да се заклучи следното: 


\begin{tabular}{|c|c|c|c|c|c|c|}
\hline \multicolumn{7}{|c|}{ ОБЈЕКТИ КОИ ВЛЕГУВААТ ВО СКЛОП НА ПРЕДИЧИЛИШНИТЕ УСТАНОВИ ,,13 НОЕМВРИ“ } \\
\hline име на објектот & група & број на деца & $\begin{array}{c}\text { норматив по } \\
\text { м на дете }^{2} \text { де }\end{array}$ & $\begin{array}{c}\text { број на } \\
\text { деца/норматив }\end{array}$ & $\begin{array}{l}\text { големина на } \\
\text { занималната }\end{array}$ & $\begin{array}{c}\text { дали го } \\
\text { задоволува }\end{array}$ \\
\hline \multirow{12}{*}{ „13 Ноември“ } & Прва јаслена група & 13 & $3,5 \mathrm{~m}^{2}$ & $45,5 \mathrm{M}^{2}$ & $50,25 \mathrm{~m}^{2}$ & $\mathrm{He}$ \\
\hline & Втора јаслена група & 18 & $3,5 \mathrm{M}^{2}$ & $63 \mathrm{M}^{2}$ & $42,25 \mathrm{M}^{2}$ & $\mathrm{He}$ \\
\hline & Прва мала група & 19 & $2,8 \mathrm{M}^{2}$ & $53 \mathrm{M}^{2}$ & $48,65 \mathrm{M}^{2}$ & $\mathrm{He}$ \\
\hline & Прва мала група & 17 & $2,8 \mathrm{M}^{2}$ & $47,6 \mathrm{M}^{2}$ & $48,65 \mathrm{M}^{2}$ & да \\
\hline & Втора мала група & 22 & $2,8 \mathrm{M}^{2}$ & $61,6 \mathrm{M}^{2}$ & $54,33 \mathrm{M}^{2}$ & $\mathrm{He}$ \\
\hline & Втора мала група & 11 & $2,8 \mathrm{M}^{2}$ & $30,8 \mathrm{M}^{2}$ & $35,5 \mathrm{M}^{2}$ & $\mathrm{He}$ \\
\hline & Втора мала група & 24 & $2,8 \mathrm{M}^{2}$ & $67,2 \mathrm{M}^{2}$ & $72,40 \mathrm{M}^{2}$ & $\mathrm{He}$ \\
\hline & Средна група & 25 & $2,8 \mathrm{M}^{2}$ & $70 \mathrm{~m}^{2}$ & $72,40 \mathrm{M}^{2}$ & $\mathrm{He}$ \\
\hline & Средна група & 20 & $2,8 \mathrm{M}^{2}$ & $56 \mathrm{~m}^{2}$ & $72,40 \mathrm{M}^{2}$ & да \\
\hline & Средна група & 22 & $2,8 \mathrm{M}^{2}$ & $61,6 \mathrm{M}^{2}$ & $72,40 \mathrm{M}^{2}$ & да \\
\hline & Голема група & 31 & $2,8 \mathrm{M}^{2}$ & $84 \mathrm{M}^{2}$ & $72,40 \mathrm{M}^{2}$ & $\mathrm{He}$ \\
\hline & Голема група & 33 & $2,8 \mathrm{M}^{2}$ & $92,4 \mathrm{M}^{2}$ & $72,40 \mathrm{M}^{2}$ & $\mathrm{He}$ \\
\hline \multirow{8}{*}{ „Парк“ } & Јаслена група & 18 & $3,5 \mathrm{M}^{2}$ & $63 \mathrm{~m}^{2}$ & $38,73 \mathrm{M}^{2}$ & $\mathrm{He}$ \\
\hline & Прва мала група & 18 & $2,8 \mathrm{M}^{2}$ & $50,4 \mathrm{M}^{2}$ & $38,73 \mathrm{M}^{2}$ & $\mathrm{He}$ \\
\hline & Прва мала група & 17 & $2,8 \mathrm{M}^{2}$ & $47,6 \mathrm{M}^{2}$ & $38,73 \mathrm{M}^{2}$ & $\mathrm{He}$ \\
\hline & Втора мала група & 16 & $2,8 \mathrm{M}^{2}$ & $44,8 \mathrm{M}^{2}$ & $38,73 \mathrm{M}^{2}$ & $\mathrm{He}$ \\
\hline & Втора мала група & 26 & $2,8 \mathrm{M}^{2}$ & $72,8 \mathrm{M}^{2}$ & $55,5 \mathrm{M}^{2}$ & $\mathrm{He}$ \\
\hline & Средна група & 28 & $2,8 \mathrm{M}^{2}$ & $78,4 \mathrm{M}^{2}$ & $55,5 \mathrm{M}^{2}$ & $\mathrm{He}$ \\
\hline & Голема група & 20 & $2,8 \mathrm{M}^{2}$ & $56 \mathrm{M}^{2}$ & $5,5 \mathrm{M}^{2}$ & да \\
\hline & Голема група & 23 & $2,8 \mathrm{M}^{2}$ & $64,4 \mathrm{M}^{2}$ & $55,5 \mathrm{M}^{2}$ & $\mathrm{He}$ \\
\hline \multirow{4}{*}{ „Јасмин“" } & Мала група & 25 & $2,8 \mathrm{M}^{2}$ & $70 \mathrm{M}^{2}$ & $65,13 \mathrm{~m}^{2}$ & $\mathrm{He}$ \\
\hline & Средна група & 29 & $2,8 \mathrm{M}^{2}$ & $81,2 \mathrm{M}^{2}$ & $67,86 \mathrm{M}^{2}$ & $\mathrm{He}$ \\
\hline & Средна група & 30 & $2,8 \mathrm{M}^{2}$ & $84 \mathrm{M}^{2}$ & $67,86 \mathrm{M}^{2}$ & $\mathrm{He}$ \\
\hline & Голема група & 26 & $2,8 \mathrm{M}^{2}$ & $72,8 \mathrm{M}^{2}$ & $65,13 \mathrm{M}^{2}$ & $\mathrm{He}$ \\
\hline
\end{tabular}




\begin{tabular}{|c|c|c|c|c|c|c|}
\hline & Голема група & 29 & $2,8 \mathrm{M}^{2}$ & $81,2 \mathrm{M}^{2}$ & $47,05 \mathrm{M}^{2}$ & $\mathrm{He}$ \\
\hline \multirow{2}{*}{ „Кукушка“ } & Мала група & 15 & $2,8 \mathrm{M}^{2}$ & $42 \mathrm{M}^{2}$ & $44,75 \mathrm{M}^{2}$ & $\mathrm{He}$ \\
\hline & Средно-голема груп & 19 & $2,8 \mathrm{M}^{2}$ & $53,2 \mathrm{M}^{2}$ & $44,75 \mathrm{M}^{2}$ & $\mathrm{He}$ \\
\hline
\end{tabular}

\begin{tabular}{|c|c|c|c|c|c|c|}
\hline \multicolumn{7}{|c|}{ ОБЈЕКТИ КОИ ВЛЕГУВААТ ВО СКЛОП НА ПРЕДИЧИЛИШНИТЕ УСТАНОВИ „КОЧО РАЦИН““ } \\
\hline име на објектот & група & број на деца & $\begin{array}{c}\text { норматив по } \\
\text { м }^{2} \text { на дете }\end{array}$ & $\begin{array}{c}\text { број на } \\
\text { деца/норматив }\end{array}$ & $\begin{array}{l}\text { големина на } \\
\text { занималната }\end{array}$ & $\begin{array}{c}\text { дали го } \\
\text { задоволува }\end{array}$ \\
\hline \multirow{10}{*}{ „Кочо Рацин“ } & Прва јаслена група & 13 & $3,5 \mathrm{M}^{2}$ & $45,5 \mathrm{M}^{2}$ & $29,62 \mathrm{~m}^{2}$ & $\mathrm{He}$ \\
\hline & Втора јаслена група & 10 & $3,5 \mathrm{M}^{2}$ & $35 \mathrm{~m}^{2}$ & $25,03 \mathrm{M}^{2}$ & $\mathrm{He}$ \\
\hline & Прва мала група & 21 & $2,8 \mathrm{M}^{2}$ & $58,8 \mathrm{M}^{2}$ & $29,44 \mathrm{M}^{2}$ & $\mathrm{He}$ \\
\hline & Прва мала група & 17 & $2,8 \mathrm{M}^{2}$ & $47,6 \mathrm{M}^{2}$ & $27,66 \mathrm{~m}^{2}$ & $\mathrm{He}$ \\
\hline & Втора мала група & 24 & $2,8 \mathrm{M}^{2}$ & $67,2 \mathrm{M}^{2}$ & $31,84 \mathrm{M}^{2}$ & $\mathrm{He}$ \\
\hline & Втора мала група & 22 & $2,8 \mathrm{M}^{2}$ & $61,6 \mathrm{M}^{2}$ & $20,12 \mathrm{M}^{2}$ & $\mathrm{He}$ \\
\hline & Средна група & 25 & $2,8 \mathrm{M}^{2}$ & $70 \mathrm{M}^{2}$ & $37,63 \mathrm{~m}^{2}$ & $\mathrm{He}$ \\
\hline & Средна група & 26 & $2,8 \mathrm{M}^{2}$ & $72,8 \mathrm{M}^{2}$ & $43,07 \mathrm{M}^{2}$ & $\mathrm{He}$ \\
\hline & Голема група & 24 & $2,8 \mathrm{M}^{2}$ & $67,2 \mathrm{M}^{2}$ & $38,36 \mathrm{M}^{2}$ & $\mathrm{He}$ \\
\hline & Голема група & 18 & $2,8 \mathrm{M}^{2}$ & $50,4 \mathrm{M}^{2}$ & $31,36 \mathrm{~m}^{2}$ & $\mathrm{He}$ \\
\hline \multirow{7}{*}{ „Бели Мугри“ } & Прва јаслена група & 13 & $3,5 \mathrm{M}^{2}$ & $45,5 \mathrm{M}^{2}$ & $38,7 \mathrm{M}^{2}$ & $\mathrm{He}$ \\
\hline & Втора јаслена група & 7 & $3,5 \mathrm{M}^{2}$ & $24,5 \mathrm{M}^{2}$ & $38,7 \mathrm{M}^{2}$ & да \\
\hline & Прва мала група & 16 & $2,8 \mathrm{M}^{2}$ & $44,8 \mathrm{M}^{2}$ & $56 \mathrm{M}^{2}$ & да \\
\hline & Втора мала група & 21 & $2,8 \mathrm{M}^{2}$ & $58,8 \mathrm{M}^{2}$ & $56 \mathrm{M}^{2}$ & да \\
\hline & Средна група & 22 & $2,8 \mathrm{M}^{2}$ & $61,6 \mathrm{M}^{2}$ & $56 \mathrm{M}^{2}$ & да \\
\hline & Средна група & 26 & $2,8 \mathrm{M}^{2}$ & $72,8 \mathrm{M}^{2}$ & $56 \mathrm{M}^{2}$ & да \\
\hline & Голема група & 26 & $2,8 \mathrm{M}^{2}$ & $72,8 \mathrm{M}^{2}$ & $56 \mathrm{M}^{2}$ & да \\
\hline
\end{tabular}




\begin{tabular}{|c|c|c|c|c|c|c|}
\hline \multirow{6}{*}{ „Панорама“؛ } & Јасли & 9 & $3,5 \mathrm{M}^{2}$ & $31,5 \mathrm{M}^{2}$ & $40 \mathrm{M}^{2}$ & да \\
\hline & Прва мала група & 16 & $2,8 \mathrm{M}^{2}$ & $44,8 \mathrm{M}^{2}$ & $40 m^{2}+40 m^{2}$ & да \\
\hline & Втора мала група & 18 & $2,8 \mathrm{M}^{2}$ & $50,4 \mathrm{M}^{2}$ & $54,75 \mathrm{M}^{2}$ & да \\
\hline & Средна група & 20 & $2,8 \mathrm{M}^{2}$ & $56 \mathrm{~m}^{2}$ & $54,75 \mathrm{M}^{2}$ & да \\
\hline & Голема група & 24 & $2,8 \mathrm{M}^{2}$ & $67,2 \mathrm{M}^{2}$ & $54,75 \mathrm{M}^{2}+54,75 \mathrm{M}^{2}$ & да \\
\hline & Германска група & 11 & $2,8 \mathrm{M}^{2}$ & $30,8 \mathrm{M}^{2}$ & $40 \mathrm{M}^{2}$ & да \\
\hline \multirow{10}{*}{ „Н.Н.Борче“ } & Прва јаслена група & 9 & $3,5 \mathrm{M}^{2}$ & $31,5 \mathrm{M}^{2}$ & $27,8 \mathrm{M}^{2}$ & $\mathrm{He}$ \\
\hline & Втора јаслена група & 9 & $3,5 \mathrm{M}^{2}$ & $31,5 \mathrm{M}^{2}$ & $39 \mathrm{~m}^{2}$ & да \\
\hline & Прва мала група & 14 & $2,8 \mathrm{M}^{2}$ & $39,2 \mathrm{M}^{2}$ & $28,25 \mathrm{M}^{2}$ & $\mathrm{He}$ \\
\hline & Прва мала група & 15 & $2,8 \mathrm{M}^{2}$ & $42 \mathrm{~m}^{2}$ & $38,53 \mathrm{M}^{2}$ & $\mathrm{He}$ \\
\hline & Втора мала група & 17 & $2,8 \mathrm{M}^{2}$ & $47,6 \mathrm{M}^{2}$ & $37,2 \mathrm{~m}^{2}$ & $\mathrm{He}$ \\
\hline & Втора мала група & 19 & $2,8 \mathrm{M}^{2}$ & $53,2 \mathrm{M}^{2}$ & $40,18 \mathrm{~m}^{2}$ & $\mathrm{He}$ \\
\hline & Средна група & 20 & $2,8 \mathrm{M}^{2}$ & $56 \mathrm{~m}^{2}$ & $40,18 \mathrm{M}^{2}$ & $\mathrm{He}$ \\
\hline & Средна група & 28 & $2,8 \mathrm{M}^{2}$ & $78,4 \mathrm{M}^{2}$ & $44,65 \mathrm{M}^{2}$ & $\mathrm{He}$ \\
\hline & Голема група & 28 & $2,8 \mathrm{M}^{2}$ & $78,4 \mathrm{M}^{2}$ & $44,65 \mathrm{M}^{2}$ & $\mathrm{He}$ \\
\hline & Голема група & 24 & $2,8 \mathrm{M}^{2}$ & $67,2 \mathrm{M}^{2}$ & $48,65 \mathrm{M}^{2}$ & $\mathrm{He}$ \\
\hline
\end{tabular}

Табела 13 


\begin{tabular}{|c|c|c|c|c|c|c|}
\hline \multicolumn{7}{|c|}{ ОБЈЕКТИ КОИ ВЛЕГУВААТ ВО СКЛОП НА ПРЕДИЧИЛИШНИТЕ УСТАНОВИ „Р.Ј.КОРЧАГИН“ } \\
\hline \multirow{7}{*}{ „P.J.Корчагин“ } & Втора јаслена & 16 & $3,5 \mathrm{~m}^{2}$ & $56 \mathrm{~m}^{2}$ & $26,1 \mathrm{~m}^{2}$ & не \\
\hline & Втора јаслена & 25 & $3,5 \mathrm{~m}^{2}$ & $87 \mathrm{M}^{2}$ & $44,9 \mathrm{~m}^{2}$ & не \\
\hline & Прва мала група & 23 & $2,8 \mathrm{~m}^{2}$ & $64,4 \mathrm{M}^{2}$ & $44,9 \mathrm{~m}^{2}$ & $\mathrm{He}$ \\
\hline & Втора мала група & 24 & $2,8 \mathrm{~m}^{2}$ & $67,2 \mathrm{M}^{2}$ & $60,6 \mathrm{~m}^{2}$ & $\mathrm{He}$ \\
\hline & Втора мала група & 26 & $2,8 \mathrm{~m}^{2}$ & $72,8 \mathrm{M}^{2}$ & $55,2 \mathrm{~m}^{2}$ & $\mathrm{He}$ \\
\hline & Средна група & 25 & $2,8 \mathrm{~m}^{2}$ & $70 \mathrm{~m}^{2}$ & $54,6 \mathrm{~m}^{2}$ & да \\
\hline & Средна група & 20 & $2,8 \mathrm{M}^{2}$ & $56 \mathrm{~m}^{2}$ & $54,6 \mathrm{M}^{2}$ & да \\
\hline \multirow{5}{*}{ „Пепелашка““ } & Јасли & 14 & $3,5 \mathrm{~m}^{2}$ & $49 \mathrm{~m}^{2}$ & $21,8 \mathrm{M}^{2}$ & $\mathrm{He}$ \\
\hline & Прва мала група & 27 & $2,8 \mathrm{~m}^{2}$ & $75,5 \mathrm{~m}^{2}$ & $25,6+16,8+16,8$ & $\mathrm{He}$ \\
\hline & Втора мала група & 29 & $2,8 \mathrm{~m}^{2}$ & $81,2 \mathrm{M}^{2}$ & $21,6+25,6+16,8+16,8$ & $\mathrm{He}$ \\
\hline & Средна група & 47 & $2,8 \mathrm{M}^{2}$ & $131,6 \mathrm{~m}^{2}$ & $21,6+25,6+16,8+16,8$ & $\mathrm{He}$ \\
\hline & Голема група & 32 & $2,8 \mathrm{M}^{2}$ & $89,6 \mathrm{M}^{2}$ & $21,6+25,6+16,8+16,8$ & $\mathrm{He}$ \\
\hline
\end{tabular}

Табела 14 
Податоците кои се добиени од сите предучилишни установи не треба да се земат како фиксни и трајни, бидејќи бројките се менуваат секој месец. Податоците за работните единици „Кочо Рацин“ и „Р. Ј. Корчагин“ се земени во месец март, а за „13 Ноември“ во месец фревруари 2011 година.

Во предучилишниот матичен објект „13 Ноември“ само три занимални го задоволуваат нормативот за големина на просториите во кои престојуваат децата и максималниот број на деца кои можат да престојуваат во една занимална. Тоа се првата мала група и средните групи. Останатите занимални и покрај тоа што го задоволуваат нормативот за големина, не го задоволуваат критериумот за максимален број на деца кои во нив престојуваат.

Во објектот „Парк“ само една занимална ги задоволува двата параметри пропишани од Правилникот за вршење на дејност на детски градинки. Останатите занимални или имаат помали димензии од минимално

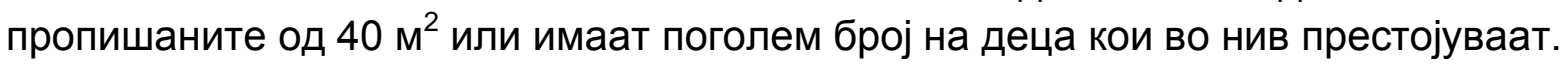

Во предучилишната установа „Јасмин“ занималните се со големина која го задоволува стандардот, но бројот на децата е поголем од пропишаниот.

Во објектот „Кукушка“, иако занималните се поголеми од минимално пропишаната големина истиот не го задоволува стандардот, поради тоа што групите се хетерогени.

Во матичниот објект „Кочо Рацин“ ниту една занимална не ги задоволува параметрите за големина на занималните, а воедно има и многу повеќе деца. Ова од причини што објектот е сместен во градба од привремен карактер.

Во предучилишната установа „Бели Мугри”, само првата јаслена група не го задоволува стандардот, поради тоа што има поголем број на деца кои престојуваат во занималаната. Останатите групи го задоволуваат пропишаниот стандард.

Во објектот „Панорама“ сите групи во кои престојуваат предучилишните деца го задоволуваат пропишаниот стандард. Во некои од занималните, иако бројот на децата е поголем од пропишаниот, оваа околност може да се прифати како задоволувачка, бидејќи се користат две занимални за една група. Во едната занимална се спие, а во другата се извршуваат психо-физички активности.

Во објектот „Наум Наумовски - Борче“, не се задоволени параматерите за големина на занималните како и бројот на децата кои во нив престојуваат. Освен во втората јаслена група, останатите занимални или имаат помали димензии или во нив има поголем број на деца од пропишаното. 
Во матичниот објект „Р. Ј. Корчагин” само две занимални го исполнуваат стандардот и тоа за средните групи. Останатите занимални и покрај тоа што имаат површини поголеми од минимално пропишаните, не го задоволуваат стандардот поради тоа што имаат поголем број на деца кои престојуваат во една занимална. Во првата и втората јаслена група, занималните се многу мали, па за нив ова е дополнителен недостаток.

Предучилишната установа „Пепелашка“ и покрај тоа што има релативно големи занимални, бројот на децата го надминува максимално дозволениот. Според тоа, ниту една група не го задоволува стандардот.

Понатаму, во трудот се обработува правилната организација на просториите во предучилишните објекти, осветлувањето, топлинската и звучната изолација. Преку правилна употреба на сите овие елементи во објектите се добива простор кој обезбедува беспрекорно функционирање.

Предучилишните објекти, како простор во кои децата поминуваат повеќе од половина ден, треба да бидат правилно и функционално организирани. Просторната организација се состои од:

- Простории каде децата престојуваат -занимална, санитарен јазол и гардероба, тријажа и тераса.

- Заеднички простории за децата - сала за повеќе намени, простор за повеќе намени, просторија за изолација, просторија за креативно изразување

- Административни простории - канцеларија за директор, канцеларија за административни работници (само во матичен објект), канцеларии за психолог, дефектолог, лекар, кабинет за наставници и негователи.

- Економско-технички простории - кујна, млечна кујна, остава за храна, перална, просторија за пеглање, шиење и складирање на чистата постелнина како и просторија во која е сместена котларницата или друг систем за централно греење.

- Комуникациски простории

Правилната просторна организација придонесува за непречено одвивање на сите функции во објектот. Со тоа треба да се задоволат условите за престој на децата, како и условите за возрасните вработени лица во објектите.

Во подглавјето 5.3. обработено е осветлувањето во предучилишните објекти. Преку правилно осветлување се подобрува процесот на учење, видот не се оштетува, се штеди во потрошувачката на електрична енергија. Осветлувањето во објектите се остварува преку природно осветлување со 
навлегување на дневна светлина или преку вештачко осветлување со помош на светлечки тела.

Природното осветлување зависи од повеќе фрактори, како:

- Предучилишните установи треба да се лоцирани на оската истокзапад, при што занималните треба да се сместени на јужната страна.

- Отвори поставени високо на sидот овозможуваат навлегување на дневната светлина подлабоко во просторијата.

- Отвори поставени од две страни ја намалуваат шансата за создавање на визуелна непријатност, појава на сјај и блескање.

- Користењето на индиректна светлина ја намалува појавата на сјај, појава на блесок или друга визуелна непријатност, за разлика од користењето на директна светлина.

- Можност за регулирање на светлината која навлегува во занималните. Кога децата спијат интезитетот на светлината треба да се намали преку венецијанер завеси, платнени завеси или слични помагала, а кога е потребно поголемо количество на светлина, за време на учење или играње, интезитетот на светлината треба да се зголеми со подигање на истите.

Во поглед на френестрацијата, можни се :

- Странични прозорци - на објекти кои имаат прозорци само од една страна или објекти кои имаат прозорци од повеќе страни.

- Прозорци високо поставени, кои ја дополнуваат светлината во просторијата заедно со страничните прозорци и

- Плафонски прозорци, кои исто така ја дополнуваат светлината во просторијата.

Во предучилишните установи во општина Центар, френестрацијата е различно поставена. Во некои има само странични прозорци од една страна, во други има прозорци од повеќе страни, а додека во трети има дополнување со високи прозорци.

Ова е изразено во следната табела: 


\begin{tabular}{|c|c|c|c|c|}
\hline име на објектот & $\begin{array}{c}\text { странични } \\
\text { прозорци } \\
\text { од една } \\
\text { страна }\end{array}$ & $\begin{array}{c}\text { странични } \\
\text { прозорци } \\
\text { од повеќе } \\
\text { страни }\end{array}$ & $\begin{array}{c}\text { високи } \\
\text { прозорци }\end{array}$ & $\begin{array}{c}\text { ориентација во } \\
\text { секој објект }\end{array}$ \\
\hline „Кочо Рацин“ & & & & сите четири страни \\
\hline „Бели Мугри“ & & & & сите четири страни \\
\hline „Панорама“ & & & & исток \\
\hline „Н.Н.Борче“ & & & & сите четири страни \\
\hline „13 Ноември“ & & & & исток - југ \\
\hline „Јасмин““ & & & & југо-запад \\
\hline „Парк“ & & & & југ \\
\hline „Кукушка“ & & & & исток \\
\hline „P.J. Корчагин“ & & & & сите четири страни \\
\hline „Пепелашка & & & & сите четири страни \\
\hline „Палешка“ & & & & север \\
\hline
\end{tabular}

Табела 15

Во подглавјето 5.4. се прави осврт на топлинската заштита и загревање во предучилишните установи. Преку правилно затоплување на просториите децата пријатно се чувствуваат при нивниот престој во објектите. Топлотната заштита е условена од голем број надворешни и внатречни фактори. Покрај ориентацијата на занималната, битен фрактор е употребата на изолационите материјали, како и материјалите употребени во главните градежни елементиsидовите, подот и плафонот. Температурата во просториите каде престојуваат децата не смее да биде пониска од $20^{\circ} \mathrm{C}$ и повисока од $22^{\circ} \mathrm{C}$.

Во подглавјето 5.5. обработена е звучната заштита во предучилишните установи. Добро изолирана просторија придонесува за правилно извршување на воспитно-образовниот процес, како и за правилен раст и развој на децата. Звучната заштита е детерминирана од поголем број на фрактори, како на пример близината на објектот до главни сообраќајници, ориентацијата на занималната, опколеноста на предучилишниот објект со други објекти, звучната изолација во самиот објект и друго. Дозволената бучава во предучилишните објекти не треба да го надминува интервалот од $35 \mathrm{~dB}-40 \mathrm{~dB}$.

Во главата 6. е направена анализа на предучилишните објекти во општина Центар, преку увид во нивната постојна состојба. Ова со цел да се извршат дополнителни интервенции во објектите, онаму каде тоа е возможно. 
Објектите кои од самиот почеток на градбата биле наменети за вршење на предучилишна дејност, ги задоволуваат сите параметри како од просторна и организациона смисла, така и во однос на осветлувањето, топлотната и звучна заштита. Објектите пак кои се пренаменети во предучилишни установи во одредени сегменти не ги задоволуваат стандардите и нормативите за вршење на дејност на детска градинка. Ова се должи на неправилната организација на просториите каде децата престојуваат, односно малите занимални. Одреден број на простории пак воопшто ги нема. Типот на градбата е исто така нестандарден.

Во главата 7 се прави антрипометриска анализа на предучилишните деца од 2 до 6 години. Мерките се направени на 80 деца, по 20 во четири групи. Опфатена е првата и втората мала група, средната и големата група. Преку оваа анализа треба да се добијат поточни податоци кои ќе користат за правилно проектирање на мебелот во предучилишните установи, како и да се направи анализа на постоечкиот мебел. Од мебелот кој се наоѓа во објектите во општина Центар направена е анализа на столчињата и масите. Констатирано е дека има два типа на столови и еден тип на маси. Постоечките димензии не коренсподираат со антропометријата добиена при мерењето на децата. Со мали измени во димензиите на седлото би се добиле столчиња и маси кои ќе бидат целосно ергономични. Добиените податоци од ергономските мерки не треба да се земат како дефиинитивно точни, бидејќ произлегуваат од мерења извршени на одредена група деца во една училишна установа. За посеопфатни и релевантни податоци, од кои би произлегло одредено правило, потребно е да се извршат мерења во сите предучилишни установи во општина Центар, на сите деца без исклучок.

Во главата 8 е даден опис на функциите кои ги обавуваат децата за време на престојот во занималните. Според видот на фуннцијата однапред е условено уредувањето и опремувањето на просторот. Функциите на предучилишните деца кои се обавуваат во занималните се:

- Спиење,

- Јадење,

- Играње,

- Воспитно- образовна активност.

Покрај наведените активности на децата, битен елемент во процесот на правилно уредување и опремување на занималните е и познавањето на психофризичките потреби на децата. Преку нив се доаѓа до сознание дека најдобро уредена основа на занималната е таа која е преградена во помали простории, каде децата можат да играат во помали групи, да се засолнуваат кога ќе имаат потреба за тоа, односно да може секое дете по своја воља да избере дали сака да биде во централниот дел од просторијата или во некое од преградените 
катчиња. Занималните кои се преградени и сочинуваат помали „џепови во просторот“, имаат предност пред занималните кои се целосно отворени или се целосно затворени и не дозволуваат визуелна достапност. Во целосно отворените занимални социјалната интеракција е помала, децата се изложени на постојани погледи, со што стануваат поагресивни и недоволно подготвени за извршување на одредени активности. Во целосно преградените занимални децата не се задржуваат долго, се чуствуваат непријатно, а воспитувачите немаат преглед врз децата. 


\section{ЗАКЛУЧОК}

Предучилишните установи се објекти во кои се извршува воспитнообразовна и згрижувачка дејност. Рамката при проектирање на овие објекти е строго контролирана и однапред ограничена од многуте фрункции кои се извршуваат во нив. Тие треба да бидат место каде особено треба да се внимава на здавјето и безбеденоста на децата, како и обезбедување на правилен социјален и едукативен развој. При проектирање, уредување и опремување на овие објекти треба да се обрне внимание и на потребите на децата. Затоа просториите каде престојуваат децата треба да се во фрнкција на самото дете.

Еден од главните предуслови за правилно функционирање на предучилишните установи претставува просторната организација. Во нив треба сите функции да бидат јасни, конкретни и недвосмислени. Притоа не треба да се занемаруваат и материјалите кои се употребуваат за изградба на објектот. Со правилно избрани материјали во просториите се постигнува визуелен, акустичен и топлотен комфор. Сите овие сегменти придонесуваат за правилен психо - фризички развој на децата, како и за пријатна атмосфера во занималните.

Според претходно кажаното во овој труд заклучоците можат да се поделат во два дела:

- Заклучоци кои се однесуваат на правилната организација на објектите и занималните

- Заклучоци кои се однесуваат на мебелот кој го користат предучилишните деца

За да се укаже на недостатоците во предучилишните установи, кои се наоѓаат на подрачјето на Град Скопје, во трудот е направена конкретна анализа на предучилшните установи во општина Центар, кои подоцна со одредени интервенции би се надминале. Исто така, се даваат одредени сугестии за правилна организација на занималните од аспект на психофизичките потреби на децата. 
Стандардот за големина на занималните, кој изнесува $3,5 \mathrm{~m}^{2}$ по дете за јаслените групи и $2,8 \mathrm{~m}^{2}$ по дете за групите на детските градинки, во споредба со светските стандарди ја става Република Македонија на задоволително место. Така на пример, имаме поголеми стандарди по м² на дете од: Јапонија $1,98 \mathrm{~m}^{2}$, Данска $2 \mathrm{~m}^{2}$, Велика Британија 2,30 $\mathrm{m}^{2}$, Германија 3,00 $\mathrm{m}^{2}$ за јасли и $2,00 \mathrm{~m}^{2}$ за детски градинки, Франција $1,5 \mathrm{~m}^{2}$ и Австрија од 2,0 $\mathrm{m}^{2}$. Поголем стандард имаат С.А.Д. со $3,25 \mathrm{~m}^{2}$, Шведска со $3,00 \mathrm{~m}^{2}$, Швајцарија со $3,50 \mathrm{~m}^{2}$ и Италија со 7,5 $\mathrm{m}^{2}$ за јасли и 10,0 м² за детски градинки. Според стандардот за бројот на деца кои треба да престојуваат во една занимална сме некаде на средина.

Проблемот кој постои во општина Центар, вклучително и во Скопје, е преголемиот број на деца во занималните. Според претходно прикажаните анализи, во однос на тоа колку од предучилишните објекти го задоволуваат стандардот за големина на занималната, се доаѓа до заклучок дека половината од вкупниот број на занимални во општина Центар имаат големина според стандардот, но бројот на децата е преголем. Другата пак половина од занималните се помали од пропишаниот минимум и имаат поголем број на деца кои во нив престојуваат. Во објектите кои од почетокот на нивната градба биле наменети за вршење на предучилишна дејност занималните се со големина според пропишаниот стандард. Тоа се објектите: 13 Ноември, „Парк“, „Јасмин“, „Бели Мугри“, „Панорама“ и „Р.Ј.Корчагин“. Во објектите кои се пренаменети за извршување на предучилишна дејност, дел од занималните се со помали димензии од пропишаниот минимум.

Од вкупно 78 занимални во сите единаесет предучилишни објекти во општина Центар, само седумнаесет го исполнуваат стандардот за големина и за бројот на деца. Изразено во проценти тоа изнесува $21 \%$ од занималните. Оттука, нужно е да се намали бројот на децата во зависност од големината на занималната. Во строгиот центар и во погусто населените реони, бројот на децата е значително поголем од проектираниот капацитет на објектите, за разлика од оние кои се наоѓаат на периферијата на општината. Поради тоа, во строгиот центар на градот треба да се изградат најмалку уште два нови предучилишни објекта.

При изградбата на предучилишните објекти треба да се свртува внимание на квантитативната распределба на занималните. Од конкретната анализа направена во општина Центар добиен е податок дека има 14 јаслени групи и 64 групи на детска градинка од кои во првата мала група има 268 деца, во втората мала група има 319 деца, средната група 421 и големата група 398 деца. Според ова, ако има 14 јаслени групи во кои престојуваат 187 деца, по стандардот за големина и вкупниот број на деца кои треба да престојуваат треба да има најмалку 20 занимални. Втората мала група користи 14 занимални, а според бројот на деца треба да има 19. Втората мала група 
користи 15, а треба да има 19, средната група има 16, а би требало да има 18 занимални и големата група има 16, а треба да има 18 занимални.

За правилен раст и развој на децата битен фрактор е правилната организација на просторот и употребата на соодветна опрема прилагодена на нивната возраст. Анализирајќи ги психо-физичките активности на децата како и функциите кои ги обавуваат мора да се проектира простор кој ќе одговара на нивниот правилен раст и развој. Во занималните треба да има делови кои ке бидат делумно преградени, бидејќи децата од оваа возраст сакаат да играат во помали групи. Преградите позитивно влијаат на децата и од аспект што тие во одреден период од денот кога ќе осетат потреба да останат сами, поради преголемата интеракција, можат да се засолнат во една од овие преградени делови. Занималните кои влегуваат во состав на објектите на општина Центар не се организирани според овој концепт. Тие се од отворен тип, кој негативно влијае на психичкиот развој на детето. Поради тоа, треба да се употреби моделот на делумно преградување на занималните. Потребно е да се преградат деловите околу ќошовите на просторијата, односно во оние занимални кои имаат поголеми димензии да се направат вакви катчиња по целата должина на занималната. Преградите може да бидат од елементите на мебелот кој се наоѓa во занималната или од играчките. Функцијата спиење би била најефектна ако е одвоена во посебна просторија, каде секое дете би го знаело своето креветче, со што ќе може да легне кога ќе посака. Исто така, во одвоената просторија полесно се одржува хигиената од причини што не е во истиот простор каде се јаде. Во предучилишните установи во општина Центар ваквиот тип на одвоено спиење не може да се постигне бидејќи објектите не се градени по овој концепт, односно занималните немаат големи димензии за еден нивен дел да се прегради како зона за спиење. Функцијата јадење може да се одвива во посебен за таа намена простор во занималните, но не претставува голем проблем ако се извршува и на просторот каде се игра и учи. Овој концепт на одвојување на јадењето во посебен дел од занималната исто така бара поголеми димензии. Другите две функции играње и воспитно образовни активности може да се одвиваат низ целиот простор од занималната зависно од желбата на детето или зададениот тип на активност од наставникот.

Во однос на мебелот кој се користи во предучилишните установи може да се изведе заклучок дека тој не соодведствува на мерките на децата. За да ги добиеме правилните димензии на мебелот, направени се антропометриски анализи, односно извршени се мерења на одредена група деца во предучилишната установа „13 Ноември“. Според добиените податоци од мерењата на столовите и масите во објектите може да се констатира дека:

- Децата од првата мала група не можат да ги користат постоечките столчиња и маси, затоа што се повисоки. За правилно седење 
треба да се проектира стол на кој димензиите на должината и висината на седлото би се промениле.

- Децата од втората мала и средна група можат да ги користат столчињата со помали димензии.

- Децата од големата група можат да ги користат столчињата со поголеми димензии, со намалување на димензијата на висината на седлото.

Постоечките маси може да ги користат само децата од големата група, додека децата од помалите групи би требало да имаат маси со помала висина. 


\section{БИБЛИОГРАФИЈА}

1. Ариес, Филип. Векови Детинства. Београд: Завод за удџбениике и наставна средства, 1989.

2. Архива на Град Скопје. Детска градинка „Трговски центар“, лок. 345\81.

3. Архива на Град Скопје. Детска градинка „13 Ноемвреи“, Д-194, 1968.

4. Архива на Град Скопје. Детска градинка „13 Ноември“ ул. 222, лок.1061\80. с-193\80

5. Архива на Град Скопје. Комбинирана детска градинка „13 Ноември“ ул. Народен Фронт, с-139\75.

6. Архива на Град Скопје. Комбинирана детска градинка „Панорама“, лок. 825\79. с-157 и $135 \backslash 79$.

7. Архива на Град Скопје. Комбинирана детска градинка „Капиштец“, лок. 474\78. c-132.

8. Архив на Република Македонија, подрачна единица Скопје. Комбинирана детска установа „Багремар '81. нас. Водно, ул. Багремар. К 93 АБ 7804.

9. Архив на Република Македонија, подрачна единица Скопје. Комбинирана детска установа „Наум Наумовски“'1974. К 49 Бр. 15918.

10. Bajbutovič, Zoran. Arhitektura školske zgrade.

11. Bayen, Mate. Shkolske zgrade. Beograd, 1962.

12. Bueno, Patricia. Kid's room. Barcelona: Atrium Group, 2004

13. Grupa autora (saradnici OECD). Društvena briga o predškolskoj deci. Beograd: Zavod za udžbenike I nastavna sredstva, 1988.

14. Department for education and skills, creating opportunity, releasing potential, achieving excellence. Bulding Bulletin 93. Acoustic design of schools. London: the stationery office, 2006.

15.Димитров Донков,Любомир. Обществњни сгради. Книга 2. София: Държавно издателство „Техника“, 1978.

16. Dudek, Mark. Kindergarten architecture. Second Edition. London: Spon Press, 2000.

17. Dudek Mark. School and kindergarten, a design manual. Bazel: Birhäuser, 2008.

18. Закон за заштита на децата. (Службен весник на Република Македонија 98/2000).

19. Закон за изменување и дополнување на законот за заштита на децата. (Службен весник на Република Македонија 63/2004).

20.3борник на трудови на друштво за науки и уметност-Прилеп. Велески Јован. Психологија на бои и колиничка пракса. Том 19/20. Прилеп: „Прилеп“, 2003/2004. [83-91] 
21. Ivanovič Šekularac, Jelena. Predškolske ustanove i komfor. Magisterski trud. Beograd: Zadužbina Andrejevič, 2000.

22. Jugoslovenski standart -JUS U.J6.201 - Tehnički uslovi za projektovanje I graћenje zgrada-akustika u zgradarstvu, 1989.

23. Jugoslovenski standart - JUS U. C9.100 - Dnevno I električno osvetluvanje prostorija i zgradama.

24. JUS.U.J6.029-Standart predučilišni stol.

25. JUS.D.E4. 021. 1965.

26. JUS.D.E4. 022. 1965.

27.JUS.P.E2.054.

28. Каменов, Емил. Предучилишна педагогија, книга прва. Скопје: Просветно дело, 1988.

29.Каранаков, Владимир. Методологија на проектирање кујникатегоризација на елементи и организација на кујни за лица со посебни потреби. Докторска дисертација. Универзитет Св. „Кирил и Методиј“ Скопје, Шумарски Факултет, Скопје, 2006.

30.Кючуков, Георги. Конструиране на мебели, врати и прозорци. София: Матком, 2004.

31.Лазаров В. Владимир. Обществњни сгради. Книга първа. София: Държавно издателство „Техника“, 1975.

32. Lueder, Rani \& Valerie J. Berg Rice. Ergonomics for children. Designing products and places for toddlers to teens. New York: Taylor \& Francis, 2008.

33. Marič, Andreja. Organizacija igre fizički hendikepirane dece u uslovima savremeno gradskog stanovanja. Doktorska disertacija. Univerzitetu u Beogradu, Arhitektonski fakultet, Beograd, 1978.

34. Министерство за труд и социјална политика. Ран детски развој, Стандарди за рано учење и развој кај деца од 0 до 6 години. Скопје: Национална и универзитетска библиотека „Св климент Охридски, 2009.

35. Николоска, Мирослава. Развојна психологија - детство. Скопје: Народна и универзитетска библиотека „св. Климент Охридски“, 2002

36. Neufert, Ernest. Arhitektonsko projektovanje. 37 prošireno I prerađeno izdanje. Beograd: građevinska kniga, 2003.

37. Panero, Julius i Martin Zelnik. Antropološke mere I enterijer. Zbirka preporaka za standard u projektovanju. Drugo izdanje. Beograd: Ggrađevinska knjiga, 1990.

38. Podđakov, N. N. Praktično mišljenje kod dece. Drugo izdanje. Beograd: Zavod za udžbenike I nastavna sredstva, 1992.

39. Правилник за стандарди и нормативите за вршење на дејноста на детска градинка. Министерство за труд и социјална политика на ребублика Македонија.( Службен весник на Република Македонија 35/2009).

40. Ridolfi, Mario. Manuale dell' architetto. Roma: Consiglio Nacionale delle Ricerche, 1975. 
41. Savetovanje "Programiranje, proektovanje I opremanje objekta za decu". Zagreb, 1973.

42. Smoljanović, Miljenko. Prilog istraživanju interakcije psihofizičkog razvoja djeteta i prostorije za boravak u predškolskim dječjim ustanovama. Doktorska disertacija. Univerzitet Sveućilišta u Zagrebu, Arhitektonski fakultet, Zagreb, 1986.

43.Станковић Б., Даница „Психолошки аспекти и проектовање дечјих предшколских установа - савремена искуства и тенденције развоја. Докторска дисертација. Универзите у Београду, Архитектонски фракултет, Београд, 2009.

44. Stevanovič, Borislav. Pedagoška psihologija. Drugo izdanje. Ljubljana: Državna založba Slovenije, 1970.

45. Stevanovič, Marko Prof. dr. Predškolska pedagogija. Druga kniga. Tuzla: R \& S, 2001.

46. Стефановски, Велко и Костантин Бахчеванџиев. Финална обработка на дрвото. Прв дел. Скопје: Шумарски фракултет, 1994.

47. Ренџов, Симеон. Играме, вежбаме, растеме. Скопје: Детска радост, 1987. 